RUY CARDOZO DE MELLO TUCUNDUVA SOBRINHO

\title{
PRESCRIÇÃO NO PROCESSO ADMINISTRATIVO DISCIPLINAR
}

TESE DE DOUTORADO APRESENTADA PERANTE A FACULDADE DE DIREITO DA UNIVERSIDADE DE SÃO PAULO.

ORIENTADOR: PROFESSOR ASSOCIADO, DOUTOR EDMIR NETTO DE ARAÚJO.

FACULDADE DE DIREITO DA UNIVERSIDADE DE SÃO PAULO

SÃO PAULO

2009

Autor: Ruy Cardozo de Mello Tucunduva Sobrinho 
Título: Prescrição no processo administrativo disciplinar.

São Paulo, de de 2009.

Banca examinadora da Faculdade de Direito da Universidade de São Paulo:

Professor Associado, Doutor Edmir Netto de Araújo (orientador).

Professor

Professor

Professor

Professor 
A passagem do tempo sempre foi objeto de estudo, em todos os ramos do conhecimento humano. E é inegável que, em muitos deles o tempo é considerado irreversível $^{1}$, por mais que a ciência - a médica é um exemplo - tente, por vezes driblá-lo; mas, no campo do Direito tal irreversibilidade pode vir - em certos casos - a ser afastada, como exemplo cite-se a possibilidade de retroatividade das leis.

O mundo jurídico dá ao tempo - compreendido em um sentido mais amplo - um tratamento peculiar, o que não significa o desprezo pelo tempo natural, mas exatamente o oposto. Institutos como a prescrição visam dar a segurança jurídica necessária a uma sociedade na qual foram criadas relações jurídicas que - após determinado lapso temporal - serão mantidas, com fulcro na paz social.

Neste trabalho procura-se demonstrar que - muito embora esteja consagrado o princípio da supremacia do interesse público sobre o particular, a Administração Pública também se sujeita à inexorável passagem do tempo e a ela não apenas é adequada, como importante à aplicação da prescrição; mormente em seus processos administrativos disciplinares.

O ordenamento jurídico não tem razão de existir, se não para organizar a sociedade e, diante disso, o estudo pretende demonstrar que a imprescritibilidade dos atos - para quem quer que seja - deve ser a exceção em uma estrutura social na qual se busca a paz e a tranquilidade, que virão necessariamente acompanhadas da segurança das relações jurídicas; e esta está umbilicalmente ligada ao fenômeno da prescrição.

Se o bem comum é o sentido maior da existência do Estado, deve ser a todo tempo buscado, e para que seja alcançado mostra-se fundamental a segurança jurídica fundamento maior de existência da prescrição; em sentido inverso, sem a prescrição não há segurança jurídica, sem segurança jurídica não se pode estruturar um Estado Democrático.

\section{DIREITO - TEMPO - PRESCRIÇÃO - PROCESSO ADMINISTRATIVO - PROCESSO ADMINISTRATIVO DISCIPLINAR - DECADÊNCIA}

\footnotetext{
ABSTRACT

${ }^{1}$ O tempo, meramente cronológico, é - naturalmente - irreversível.
} 
The passage of time has always been the object of study in all branches of human knowledge. And it is undeniable that in many time is considered irreversible, whatever the science - the medical is an example - try sometimes dribble it, but in the field of Law that irreversibility may - in some cases - the be rejected, for example cite the possibility of retroactivity of laws.

The legal world gives to the time - understood in a broader sense - a unique treatment, which does not mean contempt for the natural time, but exactly the opposite. Institutes such as the requirement to seek the necessary legal certainty to a society in which legal relations that have been established - after certain time period - will be maintained, with focus on peace.

This work seeks to demonstrate that - but is enshrined the principle of supremacy of public interest on the individual, the government is also subject to the inexorable passage of time and it is not only appropriate, as an important application of the exhaustion; especially in its administrative disciplinary proceedings.

The legal system has no reason to exist, if not for coordinating the people and, before that, the study seeks to show that the no exhaustion acts - to whoever - should be the exception in a social structure which seeks peace and tranquility, which will necessarily accompanied by security of legal relations, and this is in a very close way linked to the phenomenon of exhaustion.

If the common good is the greatest sense of the existence of the State, should be sought at any time, and that is achieved it is essential to legal security - higher ground of existence of the exhaustion; in the other way, without exhaustion we won't have a secure legal system and certainty, without that will be impossible to build a real Democracy.

LAW - TIME - EXHAUSTION - ADMINISTRATIVE PROCEDURE ADMINISTRATIVE DISCIPLINARY PROCEDURE - LIMITATION 
Il passare del tempo è sempre stato l'oggetto di studio in tutti i rami della conoscenza umana. Ed è innegabile che in molti considerato il tempo è irreversibile, qualunque sia la scienza - il medico è un esempio - a volte provare sbavare, ma nel campo del diritto che l'irreversibilità maggio - in alcuni casi - il essere respinta, per esempio citare la possibilità di retroattività delle leggi.

Il mondo giuridico è il tempo - inteso in senso più ampio - un unico trattamento, il che non significa disprezzo per il tempo naturale, ma esattamente il contrario. Istituti come l'obbligo di cercare la necessaria certezza del diritto a una società in cui i rapporti giuridici che sono stati istituiti - dopo un certo periodo di tempo - sarà mantenuto, con particolare attenzione alla pace.

Questo lavoro mira a dimostrare che - ma è sancito il principio della supremazia del pubblico interesse sui singoli, il governo è inoltre soggetta alla inesorabile passaggio del tempo e non si tratta solo del caso, come un importante applicazione della prescrizione, in particolare in il suo contesto amministrativo procedimento disciplinare.

Il sistema giuridico non ha alcuna ragione di esistere, se non per il coordinamento della società e, prima che, lo studio cerca di dimostrare che gli atti di imprescritibilidade - a chiunque - dovrebbe essere l'eccezione in una struttura sociale che cerca la pace e tranquillità, che sarà necessariamente accompagnata dalla sicurezza dei rapporti giuridici, e questo è umbilically legati al fenomeno della limitazione.

Se il bene comune è il più grande senso dell 'esistenza dello Stato, deve essere ricercata in qualsiasi momento, e che viene realizzato è fondamentale per la sicurezza giuridica - maggiore motivo di esistenza di prescrizione, nella direzione opposta senza alcuna prescrizione di sicurezza legge, senza la certezza del diritto non può costruire uno Stato Democratico.

\section{DIRITTO - TEMPO - PRESCRIZIONE - PROCEDIMENTO AMMINISTRATIVO - AMMINISTRATIVE PROCEDIMENTO DISCIPLINARE}


INTRODUÇÃO

PRIMEIRA PARTE - RESPONSABILIDADE

1. A responsabilidade dos agentes públicos. 13

2. Responsabilidade civil. 15

3. Responsabilidade penal. 17

4. Responsabilidade administrativa. 19

SEGUNDA PARTE - PRESCRIÇÃO

1. Prescrição

1.1. Fundamentos e objetivos da prescrição. 22

1.2. Prescrição no Direito Civil. 23

1.3. Prescrição no Direito Penal. 27

1.4. Prescrição no Direito Administrativo. 30

\section{TERCEIRA PARTE - PROCESSO ADMINISTRATIVO}

1. Processo administrativo.

1.1. Processo e procedimento. 34

1.2. Processo administrativo. 38

1.3. Modalidades. $\quad 40$

1.4. Princípios. 42

1.5. Fases. 42

2. Processo administrativo disciplinar.

2.1. Notas introdutórias. 45

2.2. Jus puniendi. $\quad 47$

2.3. Espécies.

2.3.1. Sindicância 48

2.3.2. Processo (sentido estrito) 49

2.4. Princípios constitucionais. 50

2.5. Fases 51 
2.6. Penalidades.

3. A prescrição no processo administrativo disciplinar. 55

3.1. Nota inicial 56

3.2. Legislação Federal. $\quad 56$

3.3. Prescrição disciplinar é algo nefasto? 57

3.4. Parágrafo $1^{\circ}$ do artigo 142 da Lei 8.112/90 58

3.5. Parágrafo $2^{\circ}$ do artigo 142 da Lei 8.112/90 70

3.6. Prescrição retroativa. 77

3.7. Prescrição intercorrente. 78

3.8. Prescrição e decadência. 82

3.9. Suspensão e interrupção da prescrição. 83

3.10. Graça, anistia e indulto.

3.10.1 Graça 85

3.10.2. Anistia 85

3.10.3. Indulto. 86

3.11. Redução dos prazos da prescrição.

4. Legislação.

4.1. Legislação federal. $\quad 88$

4.2. Legislação paulista. $\quad 89$

4.3. Legislação paulistana. $\quad 90$

5. Jurisprudência acerca da prescrição no processo

administrativo disciplinar. 90

\section{QUARTA PARTE - CONCLUSÃO}

Conclusões.

108

\section{BIBLIOGRAFIA}




\section{INTRODUÇÃO}

A passagem do tempo sempre foi objeto de estudo, em todos os ramos do conhecimento humano. E, muito embora todos tenhamos certeza da irreversibilidade da cronologia temporal, é inegável que reiteradas vezes ficamos diante de tentativas de contorná-lo - como vemos na extraordinária ciência médica contemporânea. Bem verdade que o patamar atual da ciência e da tecnologia e a perspectiva do contínuo avanço chegam perto de fazer com que acreditemos que mais dia menos dia o tempo sucumbirá...

Porém, de volta à realidade, repisemos a irreversibilidade do tempo, concretamente considerado. O objeto deste estudo é efetivamente o tempo, porém relacionando-o com o Direito e, neste campo, a regra geral do tempo (irreversibilidade), não se aplica de maneira absoluta, podendo vir - em certos casos - a ser afastada; como exemplo, cite-se a possibilidade de retroatividade das leis.

"A Lei que regeu esta conduta, ao tempo em que ela foi praticada, não era nem mesmo um projeto de lei, porém tão logo passou a existir, nos planos de validade e eficácia, foi aplicada ao ato que fora muito antes, cronologicamente falando, praticado" tal afirmação, que num primeiro momento pode parecer confusa, não o é para um acadêmico do curso de graduação em Direito; ele é perfeitamente capaz de compreender que houve uma quebra do fluxo habitual do tempo, permitindo que a Lei retroagisse e fosse aplicada a caso anterior à sua própria existência.

O mundo jurídico dá ao tempo um tratamento peculiar, o que não significa o desprezo pelo tempo natural, mas exatamente o oposto. Aristóteles já estabelece a ligação entre o tempo e o direito, da sua célebre A Política:

“a lei, na verdade, para se fazer obedecer só tem a força do hábito, o qual só se manifesta depois de muito tempo, de tal modo que passar facilmente das leis existentes para outras leis novas é enfraquecer o poder da lei." ${ }^{2}$.

Tal afirmação demonstra não apenas a existência de ligação entre o direito e o tempo, como a sua necessidade.

\footnotetext{
${ }^{2}$ ARISTÓTELES: A Política, Tradução de Therezinha Monteiro Deutsch e Baby Abrão, São Paulo, Nova Cultural, 1999, Coleção: Os Pensadores.
} 
O direito deve se perpetuar no tempo, para que a memória do passado possa dar perspectiva ao futuro. Um direito efêmero é pavimentação de uma estrada que levará à injustiça.

Mas o direito, como dito, nem sempre se prende ao tempo natural, pois para a realização da verdadeira justiça não se pode pretender um lapso temporal objetivamente calculado, contado em horas, dias e meses. Desde sempre deve ser aplicada a conhecida afirmação de Ruy Barbosa "justiça tardia é injustiça qualificada" pretendendo-se que a prestação jurisdicional seja praticada da maneira mais rápida possível; no entanto, por óbvio não pretendia Ruy que a justiça fosse realizada sem o devido amadurecimento das idéias, análise dos fatos e do direito envolvido, e isto, certamente, não pode ser calculado de outra forma, que não casuísticamente.

Nos dias atuais alguns invocam a afirmação do Águia de Haia para clamar por uma celeridade por vezes exacerbada à solução dos conflitos, lembremo-nos que nosso jurista maior jamais pretendeu que as divergências fossem apreciadas sem a devida ponderação, com a devida vênia uma paráfrase pode ser feita a afirmação do idealizador da Constituição de 1891, justiça especialmente célere pode se converter em injustiça qualificada.

Ruy Barbosa quando se refere à prestação tardia, após a passagem do tempo, mas não do tempo meramente cronológico, mas do tempo razoável que o direito leva para analisar determinada questão. Pois, após a passagem de tal lapso, muitas vezes não mais faz sentido a prestação jurisdicional; podendo até ser prejudicial à paz social. Registre-se que a duração razoável do processo inserida recentemente ao texto constitucional ${ }^{3}$ reflete com exatidão a afirmação secular da "mais poderosa máquina cerebral de nosso país" ${ }^{4}$.

Institutos como a prescrição visam dar a segurança jurídica necessária a uma sociedade, na qual foram criadas relações jurídicas que - após determinado tempo - deverão ser mantidas, buscando a vida coletiva.

Neste trabalho procura-se demonstrar que consagrado o princípio da supremacia do interesse público sobre o particular e justamente por isto, a Administração Pública também se sujeita à inexorável passagem do tempo e a ela se aplicará a prescrição, ainda que o particular seja o beneficiado em face da

\footnotetext{
${ }^{3}$ Emenda Constitucional n॰ 45 de 8 de dezembro de 2004.

4 Joaquim Nabuco, falando sobre Ruy Barbosa em sua obra Minha formação. Ministério da Cultura, Fundação Biblioteca Nacional, Departamento Nacional do Livro. Disponível em:

http://www.dominiopublico.gov.br/download/texto/bn000096.pdf, acesso aos 15 de setembro de 2008.
} 
Administração e isto não só é adequado, como salutar para o bom desenvolvimento dos trabalhos desta.

A idéia corrente que a prescrição contra a Administração Pública relativamente aos processos administrativos disciplinares permite a impunidade (e até se alia a ela) deve ser combatida, pois oriunda de raciocínio míope e simplório.

O ordenamento jurídico não tem razão de existir, se não para estruturar a sociedade e, diante disso, este estudo, partindo da regra da prescritibilidade dos atos - para quem quer que seja - procurará demonstrar que as exceções serão poucas, em uma estrutura social na qual se busca a paz e a tranquilidade, que virão necessariamente acompanhadas da segurança das relações jurídicas; e esta está umbilicalmente ligada ao fenômeno da prescrição.

A estabilidade do ordenamento, citada por Aristóteles e por Ruy Barbosa é uma preocupação que ainda aflige nossa sociedade, no dizer de Caio Mário da Silva Pereira "a prescritibilidade é a regra e a imprescritibilidade a exceção" 5 .

Com relação à existência de um poder disciplinar na Administração Pública, maiores explanações se mostram desnecessárias, pois além da possibilidade de desviar o assunto principal, a própria natureza pública dos serviços impõe a necessidade de mecanismos de controle, evitando o abuso.

Que tal poder pode - e deve - pautar a conduta do servidor público, procurando impedir quaisquer desvios nocivos ao desempenho das atividades inerentes à Administração Pública, também é evidente.

Porém, não poderá o taxado como faltoso ficar indefinidamente com uma espada de Dâmocles sobre sua cabeça ${ }^{6}$, pois tal insegurança não levaria à ordem, ao contrário; a necessidade de mecanismos impeditivos de tal situação é imperiosa.

A Administração Pública deverá ter mecanismos que lhe permitam manter sua organização, no entanto a possibilidade de punição não pode se perpetuar no tempo, sob pena de prosperar a insegurança jurídica que levará a injustiça.

\footnotetext{
${ }^{5}$ PEREIRA, Caio Mário da Silva: Instituições de Direito Civil, vol. 1., Rio de Janeiro, Forense, 1994, p. 477. ${ }^{6}$ Dâmocles era um cortesão, na corte de Dionísio I de Siracusa, que após trocar de lugar com este percebeu que os soberanos vivem permanentemente com uma espada sobre a cabeça dada a responsabilidade advinda de seus atos. Sentindo-se pressionado e permanentemente preocupado pela existência da espada, Dâmocles rapidamente solicitou voltar a seu lugar. Assim, a espada de Dâmocles demonstra o terror da insegurança.
} 
O dever da Administração de manter a ordem jamais poderá se sobrepor ao direito à segurança jurídica; tanto isso é verdade que o próprio exercício do poder disciplinar deverá ser regrado, evitando o arbítrio e o abuso.

Em outras palavras, a Administração Pública é dotada de vários poderes, dentre os quais o poder disciplinar, consistente na faculdade de punir, internamente, as infrações dos servidores e demais pessoas que, por relação jurídica de qualquer natureza (caso não haja relação contratual ou funcional tratar-se-á de Poder de Polícia ${ }^{7}$ ), se vinculam à administração e por isso se sujeitam às normas de funcionamento do serviço que integram; definitiva, temporária ou transitoriamente ${ }^{8}$, que funciona como instrumento útil à busca de seus objetivos. No entanto, partindo do objetivo maior do Estado - que é o bem comum - temos que a segurança jurídica está em patamar mais elevado, impedindo que o exercício do poder disciplinar exista ad aeternum.

Trata-se de poder-dever, na lição de Edmir Netto de Araújo, a apuração dos ilícitos e aplicação de penalidades aos servidores e particulares com vínculo contratual que deverão ter aplicadas penalidades na esfera disciplinar, uma vez que a omissão da Administração gerará responsabilidade dela. ${ }^{9}$

Aliás, no ordenamento jurídico pátrio a não apuração de irregularidade administrativa é condescendência que gera consequências no âmbito penal ${ }^{10}$. É igualmente - o poder-dever disciplinar - irrenunciável, tratando-se eventual discricionariedade neste campo, no dizer de Hely Lopes Meirelles, de verdadeiro "instrumento de cortesia administrativa" absolutamente incompatível com o direito. ${ }^{11}$

O núcleo do poder disciplinar é, portanto, o cumprimento das funções estatais; utilizando-se dos meios e formas adequados à execução, tendo o servidor ou particular com vínculo contratual conduta condizente, sob pena de aplicação de penalidades pelas faltas e desvios, sempre ressalvados ao infrator o contraditório e a amplitude de defesa.

Retornando a questão central, o poder disciplinar existe no Direito Administrativo; ocorre que neste o Estado é a matéria-prima - o

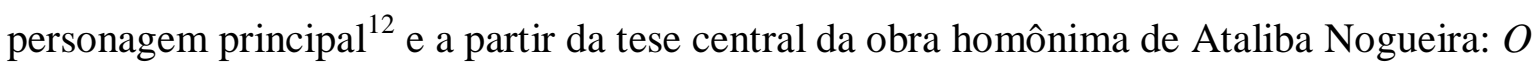

\footnotetext{
${ }^{7}$ ARAÚJO, Edmir Netto de - Curso de direito administrativo, $3^{\mathrm{a}}$ ed. São Paulo. Saraiva. 2007.

${ }^{8}$ GUIMARAES, Francisco Xavier da Silva - Regime disciplinar do servidor público civil da União, $2^{\mathrm{a}}$ ed. Rio de Janeiro, Forense, 2006.

${ }^{9}$ ARAÚJO, Edmir Netto de - Curso de direito administrativo, $3^{\text {a }}$ ed. São Paulo. Saraiva. 2007.

${ }^{10}$ Artigo 320 do Código Penal Brasileiro.

${ }^{11}$ MEIRELLES, Hely Lopes - Direito administrativo brasileiro, 20a . ed, São Paulo. Saraiva. 2000.

${ }^{12}$ ARAÚJO, Edmir Netto de - Curso de direito administrativo, $3^{\mathrm{a}}$ ed. São Paulo. Saraiva. 2007.
} 
Estado é meio e não fim $^{13}$ verifica-se que o poder disciplinar - pertencente em última análise ao Estado - não poderá sobrepor-se a um dos pilares da vida em comunidade, que é a segurança jurídica, garantidora da coexistência pacífica entre os homens.

O presente trabalho pretende, partindo da responsabilidade das pessoas sujeitas ao poder disciplinar da Administração Pública e da fundamentação teórica para a existência e exercício de tal poder, demonstrar a existência de prescrição aplicável à Administração, nos processos administrativos disciplinares, bem como colocar luz sobre questões que a legislação tende a tornar tormentosas - como a fixação do dies a quo ou a relação entre a prescrição penal e a administrativa, entre outras.

O núcleo do poder disciplinar está na Lei e no interesse público pretendendo trazer decisão justa fundamentada na legalidade, não havendo espaço para o arbítrio ou perseguições. Porém, da mesma forma que a impunidade funcional deve ser rechaçada, a perene insegurança merece o mesmo repúdio de forma que entre os limites impostos ao poder disciplinar estará o temporal, expresso pela prescrição.

A aplicação do sistema legal deverá estar em consonância com todos os ditames consagrados pela Constituição Federal, o que - como se pretende demonstrar - nem sempre está refletido na legislação que trata acerca dos lapsos prescricionais.

O processo administrativo disciplinar é espécie do gênero processo administrativo e este por sua vez - embora não jurisdicional - também deve ser considerado e estudado enquanto processo, na acepção jurídica da palavra.

A apuração da responsabilidade, conforme dito, é direito da Administração Pública, perante aqueles cujo vínculo jurídico permita a aplicação de penalidade e um dever perante toda a sociedade de administrados; no entanto, o interesse maior de tais pessoas é a convivência estruturada e pacífica, qualificada pela segurança jurídica que só é possível diante de uma administração regrada, na qual a prescrição exista com a finalidade maior da busca da paz social.

O poder disciplinar existe como instrumento a serviço da Administração Pública e tem o escopo de inibir e punir as infrações, mas faz parte de um sistema maior onde impera a legalidade e no qual não existe espaço para a perpetuação de situações indefinidas juridicamente, sob pena de prosperar o ilógico dentro de um Estado democrático.

\footnotetext{
${ }^{13}$ NOGUEIRA, José Carlos de - O Estado é meio e não fim, São Paulo, Saraiva, 1955.
} 


\section{PRIMEIRA PARTE - RESPONSABILIDADE}

\section{A responsabilidade dos agentes públicos.}

O agente público é "todo aquele que, de alguma forma, sob qualquer categoria ou título jurídico, desempenha função ou atribuição considerada pelo Poder Público como a si pertinente, seja em virtude de relação de trabalho (estatutária ou não), seja em razão de relação contratual, encargo público ou qualquer outra forma de função de natureza pública, enquanto a desempenhar". ${ }^{14}$

O Estado, como é sabido responde de maneira objetiva pelos seus atos, importando na desnecessidade do administrado provar a culpa direta ou indireta do Estado.

"O Estado responde por danos causados aos particulares por seu agente, por ação ou por omissão, ou mesmo que não se identifique o causador, mas seja o dano referível ao Estado pelo serviço público ou por coisas à sua guarda (...) Mesmo na hipótese da omissão estatal (em que o serviço público não funcionou, funcionou tardiamente ou de forma deficiente), depreende-se da leitura do artigo $37, \S 6^{\circ}$, da Constituição Federal, que a regra do ordenamento jurídico brasileiro é clara: responsabilidade objetiva do Estado, baseada na teoria do risco, independentemente de dolo ou de culpa do agente, levando-se em conta esta culpa ou dolo somente para fins de ação regressiva. O Estado só se eximirá da obrigação de indenizar excepcionalmente, em caso de excludentes de responsabilidade." 15

Muito se fala, ao se tratar de responsabilidade objetiva do Estado, que àquele que decidir exercitar o seu direito ante ao Poder Público é beneficiado pela chamada inversão do ônus da prova; entretanto tal pensamento não encontra respaldo técnico.

A regra do artigo 333 do Código de Processo Civil, que é aplicável à Administração Pública, mais cristalina não poderia ser. Tendo em vista que a Administração pretende demonstrar fato impeditivo, modificativo ou extintivo do direito, trata-se de prova a seu cargo (conforme explícito no inciso II do supracitado artigo). Em verdade, não ocorre qualquer inversão.

\footnotetext{
${ }^{14}$ ARAÚJO, Edmir Netto de - Curso de Direito Administrativo, $3^{\mathrm{a}}$ ed São Paulo, Saraiva, 2007.

15 FRANCO, João Honório de Souza - Responsabilidade extracontratual do Estado e improbidade administrativa, Dissertação de Mestrado FADUSP, São Paulo, 2007.
} 
Diferentemente do que ocorre, por exemplo, no Código de Defesa do Consumidor quando o juiz pode, segundo o artigo $6^{\circ}$, VII, efetivamente inverter o ônus da prova, ficando o consumidor dispensado de demonstrar suas alegações, bastando à verossimilhança delas. Em tal situação, o consumidor está em patamar mais privilegiado que aquele que sofreu dano perpetrado pela Administração Pública.

Voltando à responsabilidade dos agentes do Estado, que é a que interessa mais de perto neste trabalho, o agente, como visto, poderá ser responsabilizado posteriormente, por meio de ação regressiva, se houver prova de sua culpabilidade.

Mas, o Estado, para que a ação regressiva - por força da indisponibilidade do interesse público - seja um dever, não poderá a qualquer tempo ingressar com tal demanda, uma vez que também contra ele existe o prazo prescricional.

Com relação ao agente público, as consequências que ele poderá pessoalmente sofrer são divididas basicamente em uma trilogia ${ }^{16}$; responsabilidade penal, civil e administrativa (disciplinar e funcional).

Inicialmente, de se dizer que as três espécies de responsabilidade são independentes, podendo o mesmo ato gerar uma, duas ou todas as três.

Em regra a responsabilidade administrativa precederá as demais, uma vez que o ato ou omissão apto a gerar um dano patrimonial (responsabilidade civil) ou que configure infração à lei penal (responsabilidade penal) será conduta a ser averiguada pela Administração e provavelmente gerará responsabilidade administrativa.

A questão muitas vezes suscitada diz respeito ao brocardo non bis in idem. Estaria a regra da impossibilidade de punição em duplicidade pelo mesmo fato sendo ferida? Não, não está.

A regra diz respeito à punição em duplicidade, no mesmo campo e não a respeito de eventual dupla punição, quando atingidos campos diversos. Melhor explicando, deve ser a responsabilidade ser considerada de forma tripartida em administrativa, civil e penal; cada uma tutelando um bem jurídico diverso.

\footnotetext{
${ }^{16}$ ARAÚJO, Edmir Netto de: Curso de Direito Administrativo, $3^{\mathrm{a}}$ ed, São Paulo, Saraiva, 2007.
} 
$\mathrm{Na}$ responsabilidade administrativa a conduta atinge a Administração Pública; na civil o patrimônio e na penal a sociedade. Sendo assim, a máxima non bis in idem está relacionada com punição em duplicidade, ou dupla punição no mesmo campo, pela mesma falta, o que é diferente de punições diversas em campos distintos por conta de uma conduta que atingiu mais de um bem.

Sendo assim, não há possibilidade de serem confundidas as responsabilidades de natureza civil, penal e administrativa; não obstante são comuns casos de existência de mais de uma delas, exatamente pela coexistência de relações jurídicas diversas entre as pessoas. Cada relação jurídica deverá ser solucionada no campo do direito correspondente.

Note-se, outrossim, que a responsabilidade não pode ser classificada enquanto parcial ou relativa, ela é sempre total. Responsabilidade não possui gradação possível.

De duas, uma. Ou a responsabilidade existe, ou não existe.

O fato é que cada um de nós é responsável pela integridade de seus atos, o que pode corresponder a apenas parcela do dano e isto é confundido com responsabilidade parcial que, repise-se, inexiste.

\section{Responsabilidade civil.}

A responsabilidade civil, para os agentes públicos, dependerá da co-existência de três fatores: a ação ou omissão do agente, agindo nesta condição, qualificada pelo elemento subjetivo (que será o dolo ou a culpa).

Tal responsabilidade tem um viés patrimonial evidente, e pretende restabelecer a ordem existente antes da conduta lesiva.

Nas palavras de Edmir Netto de Araújo, "é a obrigatoriedade de ressarcimento ou reparação pelo culpado direto ou indireto do dano causado, ou seja, pelo responsável pela ação ou omissão danosa ou lesiva ao patrimônio por elas afetado" (itálico do original).

Em resumo, trata-se da necessidade de reequilíbrio dos patrimônios envolvidos. 
Note-se que o dano causado pelo agente pode ser no patrimônio de um particular ou do próprio Estado - no primeiro caso haverá a já mencionada responsabilidade objetiva do Estado que regressivamente acionará o servidor, já no dano direto ao Estado um melhor detalhamento se impõe. E, isto porque anteriormente a legislação ${ }^{17}$ admitia o desconto compulsório, feito no pagamento, após a caracterização da responsabilidade civil do servidor; porém, atualmente os estatutos tendem a permitir a autoexecutoriedade apenas excepcionalmente. É o que ocorre no Município de São Paulo, no Estado de São Paulo e na União, vejamos:

No Município e no Estado o desconto é permitido, desde que não ultrapasse a décima parte do vencimento líquido do servidor (exceto em casos de alcance, desfalque, remissão ou omissão em efetuar recolhimentos ou entradas nos prazos legais - quando reposição em única parcela) e que este tenha agido com dolo ou culpa demonstrados.

Já os servidores da União o desconto compulsório é ainda mais restrito, podendo ser aplicado subsidiariamente quando o prejuízo tenha sido causado dolosamente e não haja bens do servidor ou de seus sucessores aptos a assegurar a solvência do débito na via judicial. Ainda neste caso o desconto não poderá superar um décimo da remuneração ou provento.

Em se falando de atos dolosos, até mesmo o empregado celetista poderá sofrer desconto, nos termos do na última parte do parágrafo $1^{\circ}$ do artigo 462 da CLT.

Os doutrinadores afirmam que, caso haja

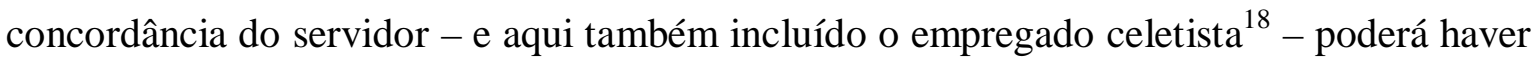
o desconto. Mas daí não mais se tratará de autoexecutoriedade, que se caracteriza pela imposição e não pelo acordo.

Em outras palavras, hoje a autoexecutoriedade de débitos de servidores perante a administração é a exceção e a cobrança judicial a regra.

A responsabilidade civil do agente será perante o Estado, tenham sido causados danos a terceiros ou ao Estado diretamente. Todavia nem a doutrina, tampouco a jurisprudência e muito menos a legislação, impedem que o

\footnotetext{
${ }^{17}$ Lei 1.711 de 28 de outubro de 1952 .

18 Ainda que haja concordância do empregado temos que o desconto não é possível, face ao disposto no artigo 7॰, VI da CF, que exige convenção ou acordo coletivo.
} 
prejudicado acione diretamente o agente público, cuja responsabilidade é subjetiva. Em tal caso, cumprindo o servidor sua obrigação, não mais poderá ser o Estado acionado.

\section{Responsabilidade penal.}

Com relação à responsabilidade penal, esta subsistirá quando a conduta do agente tipificar ilícito previsto na legislação penal.

Em tal caso, a Administração Pública e o Poder Judiciário deverão apurar a ação (ou omissão) do agente com o fito de efetiva punição caso seja constatada sua responsabilidade, uma vez que as infrações que estão previstas na legislação penal são - em regra - gravíssimas perante a Administração Pública, entretanto, caso o ilícito seja exclusivamente penal, a já mencionada independência das instâncias impedirá qualquer punição administrativa ${ }^{19}$.

Sobre o tema, pronuncia-se Edmir Netto de Araújo tanto em seu em seu $O$ ilícito administrativo (São Paulo, RT, 1994) quanto no Curso de direito administrativo (São Paulo, Saraiva, 2007). O mencionado autor triparte o estudo da responsabilidade penal em: ilícito administrativo, puro e penal; crimes contra a Administração e crimes comuns.

O ilícito administrativo puro é aquele que muito embora fira a legislação administrativa, não está em descompasso com o ordenamento penal. Ou seja, não é crime, mas será objeto de apuração e de eventual punição administrativa. E o espectro de atuação disciplinar em reprimenda a comportamentos indesejados é muito mais amplo que o do direito penal, mormente com relação à tipicidade estrita ou de uma relação numerus clausus das condutas que possam ser apenadas. Resta à autoridade administrativa uma discricionariedade mais ampla - que não se confunde com arbítrio - que àquela conferida judicialmente.

Já o ilícito administrativo penal é o ato que perante o ordenamento jurídico a um só passo caracteriza-se como contrário a ambas as leis (penais e administrativas) tendo reflexos nas duas esferas. Tais penalidades serão desvinculadas entre si, muito embora possam vir a influenciar-se reciprocamente.

E a distinção dos campos de incidência de cada uma das penalidades vem a partir do bem jurídico atingido; muito embora direito penal quanto o

\footnotetext{
${ }^{19}$ Trata-se de mera elucubração, pois em regra a prática de crime é por si ilícita administrativamente.
} 
direito administrativo sejam ramos do direito público (e, portanto tenham em comum a tutela maior do interesse público) em uma visão mais detalhada pode-se perceber que no ilícito administrativo o bem tutelado é o Estado internamente, em sua estrutura, já no ilícito penal o Estado será alvejado externamente, na tutela do bom convívio da sociedade. Assim, após apurada a conduta, dada a independência das instâncias - oriunda do bem jurídico especificamente tutelado, poderá haver punição em nenhuma delas, em ambas ou em apenas uma delas.

Posta assim a diferença entre o ilícito administrativo e o penal, forçosa a conclusão que no ilícito administrativo puro existe distinção em sua natureza em face do ilícito penal; fato que não se repete no ilícito administrativo penal, uma vez que muito embora cada ramo do direito (no caso Administrativo e Penal) trate separadamente do bem jurídico atingido, a ilicitude do ato - praticado pelo agente público - confunde-se nos dois campos, não havendo - então - diferença ontológica entre eles.

Pondera Edmir Netto de Araújo que "o ilícito administrativo penal, como figura delituosa, geralmente pertence à categoria dos chamados crimes especiais (ou oficiais, ou funcionais), que exigem a existência de certa qualificação do sujeito ativo, em contraposição aos crimes comuns, que não exigem qualidade especial do agente, embora existam crimes que o funcionário pratica como cidadão comum e que também constituem ilícito administrativo." Lembrando, ainda, que a qualidade de funcionário público pode vir a ser comunicada ao particular, em caso de co-autoria.

Convém lembrar que a maioria dos crimes pode ser praticada por qualquer pessoa, são os chamados crimes comuns; para outros, no entanto, é necessária a existência de uma capacidade especial, ou, no dizer dos penalistas, certa posição jurídica (funcionário público, por exemplo) ou fato (gestante). Tais delitos poderão ser crimes próprios ou especiais e ainda delitos de mão própria ou de atuação pessoal. A qualidade de funcionário público pode ser classificada de várias maneiras, como: elementar do tipo (artigo 312 do CP) nestes casos serão crimes próprios; qualificadora do delito (artigo 327, parágrafo 2॰); causa especial de aumento de pena (artigo 311 do CP) e, até mesmo norma permissiva de exclusão de crime (artigo 142, III). ${ }^{20}$

Em regra, o ilícito administrativo penal será um crime próprio, ou seja, cuja qualidade de servidor (funcionário na terminologia do Código Penal) é exigida no próprio tipo. Mas, nada impede que seja um delito comum, praticável

\footnotetext{
${ }^{20}$ MIRABETE, Júlio Fabrini: Manual de Direito Penal, 20ª ed, São Paulo, Atlas, 2003.
} 
por qualquer pessoa, mas que, a qualidade de servidor do agente traz diferencial a ser considerado como agravante, por exemplo. Em verdade a prática de crime pelo servidor em tal qualidade - já é, por si, considerada uma transgressão administrativa, tanto no âmbito federal, quanto no estadual e municipal. ${ }^{21}$

Em praticando o servidor - nesta qualidade - um delito, ressente-se a Administração, mormente em face do princípio da moralidade, consagrado pela Constituição Federal em seu artigo 37, caput. Atingida a Administração, fica o agente passível de punição em tal esfera e, dada a prática de delito penal, impõe-se a apuração e eventual condenação neste âmbito.

Nos delitos puníveis junto à justiça comum, não apenas encontramos crimes, mas também as contravenções. Estas devem ser analisadas tal qual é feito com os crimes; ou seja, a prática de uma contravenção poderá ensejar punição no campo penal e administrativo, o que se dará de maneira independente, de acordo com o bem jurídico lesionado.

\section{Responsabilidade administrativa.}

A responsabilidade administrativa dos agentes públicos pode ser analisada em sentido amplo ou em sentido estrito.

Em sentido amplo ela engloba as duas categorias acima expostas, uma vez que encampa todo e qualquer ato praticado pelo agente público no exercício de suas funções. Tal ato, eventualmente acarretará em responsabilidade civil ou responsabilidade penal (por vezes ambas), mas certamente irá o agente responder pela responsabilidade administrativa em sentido estrito.

Esta última pode ser conceituada como a obrigação do agente público responder perante a Administração Pública pela prática de ilícito administrativo.

Tal conceito, aparentemente singelo, merece ser esmiuçado para que não haja dúvidas a respeito de sua abrangência.

Então vejamos:

A obrigação (não se trata de mera faculdade) do agente público (conforme conceituado na primeira parte, item 1 deste trabalho) responder

\footnotetext{
${ }^{21}$ Em se tratando do Estado de São Paulo e do Município de São Paulo.
} 
perante a Administração Pública (trata-se de procedimento administrativo e não judicial) pela prática de ilícito administrativo (normas impostas pela Administração, por qualquer meio, para regulamentar a atividade de seus agentes).

Note-se que o conceito de agente público deverá ser abrangente, uma vez que todas aquelas pessoas que se enquadrem nele estarão sujeitas à prática de ilícitos administrativos e não apenas aqueles que - segundo anteriormente pensou a doutrina - fossem servidores públicos estatutários.

Outrossim, deve ser levado em consideração que os ilícitos administrativos podem ser de duas ordens, os disciplinares e os funcionais ${ }^{22}$.

Por ilícitos disciplinares devem ser entendidos aqueles que ferem a hierarquia, de outro lado os ilícitos funcionais serão os que estiverem em desacordo com normas de conduta relativas às atribuições do agente.

Assim, pode ser verificado que a distinção não se dá de acordo com a eventual punição disciplinar, mas sim em referência a conduta externada pelo agente.

Outra característica da responsabilidade administrativa é que em seu âmbito não existe a figura dos irresponsáveis, que são, em termos leigos, aqueles que não dão suporte aos seus atos, que não mantém compromissos assumidos; em termos legais os irresponsáveis são os considerados relativa ou absolutamente incapazes, cuja compreensão acerca do fato delituoso, ao tempo da ação ou omissão, não existia ou era deficiente. Trata-se de presunção legal, em regra juris tantum, cuja comprovação excluirá a responsabilidade civil ou criminal do sujeito. São os legalmente inimputáveis ${ }^{23}$.

Porém, na Administração Pública a irresponsabilidade - incapacidade - funcional inexiste, uma vez que a presunção é a capacidade física e mental do servidor, verificada antes de sua contratação. Apenas é admitida a incapacidade superveniente, que - por óbvio - não pode ser afastada antes de formalizado o vínculo. Em outras palavras, não há inimputabilidade administrativa, mormente do Direito Administrativo Disciplinar.

Apurar a responsabilidade administrativa é dever da Administração, ainda que satisfeita a responsabilidade civil com a reparação material do

\footnotetext{
${ }^{22}$ ARAÚJO, Edmir Netto de: Curso de Direito Administrativo, $3^{\text {a }}$ ed, São Paulo, Saraiva, 2007, p. 714.

${ }^{23}$ Neste sentido confira-se os artigos 26 e 27 do Código Penal e o artigo 1• e seguintes do Código Civil.
} 
dano, ou mesmo da responsabilidade penal, com processo criminal transitado em julgado. Impõe-se a independência das instâncias.

A Administração deve, sempre - e até sob pena de responsabilidade, caso assim não haja - apurar a verdade, e punir sempre que for cabível, uma vez que o interesse da administração é in casu indisponível, sendo incabíveis quaisquer menções à conveniência ou oportunidade da apuração. O prejuízo econômico à Administração não possui maior relevância, havendo ou não, deve a Administração apurar eventuais ofensas funcionais ou disciplinares de seus agentes, no sentido mais amplo que tal expressão pode receber.

Esta determinação rígida e necessária deverá ser seguida sempre, não havendo espaço para bagatelas, potencial danoso mínimo, reparação civil do dano ou quaisquer outras teorias ou fatos que pretendam excluir ou impedir a apuração administrativa.

A apuração seguirá o devido processo legal, sempre amparado pelo contraditório e pela ampla defesa; não mais sendo possível que a autoridade, tendo conhecimento direto e imediato de falta leve aplique a verdade sabida, forma sumária de punição do servidor cujo caso se enquadrasse nas circunstâncias acima descritas.

Para que haja punição, deverá a Administração proceder à apuração por intermédio de sindicância ou processo administrativo, dos quais se tratará oportunamente. 


\section{SEGUNDA PARTE - PRESCRIÇÃO}

\section{Prescrição.}

\subsection{Breve histórico, fundamentos e objetivos da prescrição.}

$\mathrm{Na}$ tese central de sua obra $O$ tempo do direito, François Ost sustenta que o direito afeta diretamente a temporalização do tempo (visto basicamente como uma construção social), ao passo que, em troca, o tempo determina a força instituinte do direito ${ }^{24}$. Sustenta o jurista e filósofo francês que as relações entre tempo e direito são muito mais profundas do que as comumente estudadas.

Partindo do princípio que a paz social é a razão maior da existência do direito, não encontra respaldo um direito efêmero, causador de absoluta incerteza; o tempo deve trazer certeza e não gerar insegurança para os administrados ou para quem quer que seja. O passado, cuja importância não se ignora, não pode ser visto como impeditivo para a convivência social harmônica.

O passado, por vezes deve ser deixado de lado - não esquecido - para viabilizar um futuro mais justo, neste sentido invocamos a afirmação de Desmond Tutu, Prêmio Nobel da Paz, presidente da Comissão sul africana "Verdade e Reconciliação" instituída em 1995, após décadas de apartheid: "Não afirmamos que devemos fechar os olhos para nosso passado. Mas a justiça não pode processar todo mundo, isto não teria fim”.

A prescrição, cuja essência é a mesma da anistia, surge, como forma de trazer ao campo da certeza jurídica situações que não estavam na seara da legalidade; é um princípio de ordem pública com o fito de estabilizar as relações jurídicas. A primeira forma de prescrição conhecida no Direito Romano foi a usucapio, primórdio do usucapião, até os dias atuais conhecido como forma de prescrição aquisitiva, no entanto - naquele tempo as ações no jus civile eram permanentes, a Lei das XII Tábuas não admitia o fator tempo como fator extintivo no direito, o ato nulo não existia do ponto de vista legal, impedindo qualquer produção de efeito jurídico.

Mas desde a era romana foi percebida a necessidade da extinção das ações em virtude do não exercício, e os pretores passaram a trazer tal noção em seus julgamentos. E, até os dias de hoje a inércia do titular durante certo lapso

\footnotetext{
${ }^{24}$ OST, François - O tempo do direito, São Paulo, EDUSC, 2005.
} 
temporal permanece como fulcro da prescrição, a doutrina é, outrossim, praticamente unânime ao afirmar que a prescrição é causa extintiva (seja do direito, da ação ou da pretensão, como será visto adiante), todavia, Pontes de Miranda sustenta que os efeitos operados são meramente neutralizantes e não extintivos da ação ${ }^{25}$.

Quanto a tal aspecto, ainda que de maneira tímida parte da doutrina sustenta que a prescrição atinge o direito ${ }^{26}$ e outra parte - majoritária considera que o que é atingido é a ação ${ }^{27}$ (mas, mesmo dentro desta última corrente, existem aqueles que sustentam que o direito é atingido por via reflexa ${ }^{28}$ ) e uma derradeira corrente doutrinária sugere que a prescrição atinge a pretensão, e indiretamente a ação.

Em que pese tal discussão, certa é a necessidade da existência da prescrição, pois uma simples compra e venda tornar-se-ia impraticável sem tal instituto, afinal estaria o comprador obrigado a ter certeza que todos os negócios realizados com aquele bem, ao longo dos séculos, fossem perfeitamente lícitos, pois, uma única falha comprometeria as alienações posteriores, tornando as transações jurídicas praticamente inviáveis. ${ }^{29}$.

A prescrição é princípio informador do ordenamento jurídico, que não admite a perpétua incerteza quanto à estabilidade das situações constituídas. É regra geral, de ordem pública, que se inscreve nos estatutos civis, comerciais, no âmbito do Direito do Trabalho, do Direito do Consumidor, do Direito Administrativo, do Direito Penal etc. ${ }^{30}$ Como sabido, os prazos podem ser suspensos ou interrompidos, o que também é aplicável à prescrição; nas causas interruptivas reinicia-se a contagem do prazo; já nas causas suspensivas a contagem recomeçará do ponto onde havia parado, tão logo seja removida a causa que ensejou a paralisação do prazo prescricional.

\subsection{Prescrição no Direito Civil.}

No Direito Civil a prescrição está regulamentada a partir do artigo 189 do Código, que - a partir de sua edição - determinou a alegação pela

\footnotetext{
${ }^{25}$ MIRANDA, Francisco Pontes de: Tratado de Direito Privado, parte geral. $2^{\mathrm{a}}$ ed. Rio de Janeiro, Borsoi, 1955. t. 5 e 6.

${ }^{26}$ GOMES, Orlando: Introdução ao Direito Civil. 6. ed. Rio de Janeiro, Forense, 1979.

${ }^{27}$ PLANIOL, Marcel; RIPERT, Georges: Tratado practico de Derecho Civil Francés: las obligaciones: segunda parte. Habana: Cultural. 1945. t.7. Tradução de Mario Diaz Cruz.

${ }^{28}$ CARPENTER, Luiz F.: Da Prescrição. Artigos 161 a 179 do Código Civil. $3^{\text {a }}$ ed. Rio de Janeiro: Nacional de Direito, 1958. v.1. notas de Arnoldo Wald.

${ }^{29}$ MONTEIRO, Washington de Barros: Curso de Direito Civil, São Paulo, Saraiva, 2006.

${ }^{30}$ NASSAR, Elody: Prescriçao na Administração Pública, São Paulo, Saraiva, 2004.
} 
parte a quem aproveita, impedindo expressamente o reconhecimento de ofício pelo magistrado. Pode ser a qualquer tempo alegada, porém ao réu que permanecer silente na contestação - quando já alcançado o lapso prescricional não caberão honorários advocatícios em seu proveito, segundo o artigo 22 do Código de Processo Civil.

Em regra a alegação da prescrição deverá ser feita na fase cognitiva do processo, muito embora haja exceções, por exemplo, quando existe prescrição superveniente à sentença - caso em que poderá ser alegada em sede de execução; outrossim, a falta de menção opportuno tempore impede a alegação quando do recurso especial ou extraordinário, o mesmo ocorrendo na ação rescisória.

Como mencionado, o Código Civil determinou que as partes que devem alegar a ocorrência de prescrição, exceto na tutela de interesses de absolutamente incapazes, quando não só o Ministério Público - por óbvio - pode solicitar o reconhecimento, como também o magistrado reconhecê-la de ofício.

Tal posicionamento foi acolhido e aplaudido pela doutrina:

Se ele não o exerce porque não quer exercê-lo, e não quer exercê-lo porque tem interesse jurídico em ver a lide resolvida com a rejeição da pretensão deduzida em juízo contra o legitimado passivo, não é dado ao juiz o conhecimento ex officio da prescrição, como se estatui no Código Civil brasileiro, art. 194, $1^{a}$ parte, e como é estabelecido na legislação comparada. ${ }^{31}$

Com relação aos curadores, estes - como partes estão legitimados para a invocação, porém, interessante de se notar que o representante do Ministério Público, atuando como mero custos legis não está apto a invocar a ocorrência de prescrição, uma vez que isto levaria ao atingimento por via oblíqua da norma ${ }^{32}$. Em

\footnotetext{
${ }^{31}$ ALVES, Vilson Rodrigues: Da Prescrição e da Decadência no Novo Código Civil, Campinas, Bookseller, 2003, p. 528.

${ }^{32}$ FARIAS, Cristiano Chaves de: Direito Civil. Teoria Geral. $3^{\text {a }}$ Edição, Rio de Janeiro, Lúmen Juris 2005, p. 508.
} 
contraposição a tal posicionamento, Maria Helena Diniz ${ }^{33}$ suscita que toda e qualquer incapacidade geraria ao parquet a possibilidade de intervenção.

No entanto, não foi o já citado artigo 194 de Código Civil recepcionado sem críticas. Atenta a necessária impressão de celeridade à justiça, bem como à eficiência da prestação jurisdicional a doutrina criticou a impossibilidade do reconhecimento da prescrição pelos magistrados, fato que resultou na lei federal 11.280, de 16 de fevereiro de 2006, que revogou o artigo 194 do Código Civil e alterou o parágrafo $5^{\circ}$ do artigo 219 do CPC, que passaram a determinar que o juiz pronuncie - de ofício - a ocorrência da prescrição.

Assim, hoje o juiz possui o dever de pronunciar eventual prescrição, de ofício, em todos os casos, inclusive nos direitos patrimoniais ${ }^{34}$ com a consequente extinção do processo no julgamento do mérito. Ficando consagrado no ordenamento jurídico pátrio o respeito segurança jurídica.

A disposição atual será benéfica à Fazenda Pública, principal prejudicada com a anterior mudança - advinda com o Código Civil de 2002 - que obstara o reconhecimento em casos relativos a direitos indisponíveis, porque o magistrado poderá suprir a não-alegação por parte dos procuradores judiciais daquela, visto que a quantidade de processos instaurados nos quais a mesma figura como parte é enorme e não há como se ter um controle absoluto sobre todos os prazos prescricionais. ${ }^{35} \mathrm{O}$ Ministério Público também terá papel de destaque, vez que como custos legis deverá apontar todos os casos onde houve prescrição.

A doutrina tem se mostrado reticente em adotar as novas regras, que impediriam, em tese, a renúncia ao prazo prescricional ${ }^{36}$ ou a revelia, por exemplo, caso o magistrado reconheça a prescrição antes da citação. Críticas surgem e, muito embora seja louvada a preocupação do legislador em dar maior celeridade e eficiência para a prestação jurisdicional, as consequências da reforma processual repercutem, podendo ampliar o número de demandas, mormente em segunda instância, tornando-se contraproducente.

Porém, também tem a doutrina procurado demonstrar que é possível que os magistrados, ao aplicar a norma a interpretem, minimizando

${ }^{33}$ Comentários ao Código Civil. São Paulo, Saraiva, 2005.

${ }^{34}$ Tendo em vista que o Código Civil anterior vedava expressamente (no artigo 166) tal prática, e que tal diploma vigorou por mais de 80 anos, importante salientar a mudança.

${ }^{35}$ ARAPIRACA, Ciro José de Andrade: A Lei 11.280/06 e o reconhecimento de ofício da prescrição, disponível em: www.juspodivm.com.br, acesso em 10 de dezembro de 2008.

${ }^{36}$ Artigo 191 do Código Civil. 
eventuais efeitos prejudiciais à mens legis, que pretendeu evitar demandas inúteis e não multiplicá-las. Com isso não se pretende adotar interpretações extremistas que sugerem a aplicação ex officio apenas das questões de direitos não patrimoniais, fato que por si seria contra legem.

A respeito, ainda, dos prazos da prescrição no Direito Civil, necessárias algumas considerações sobre as alterações trazidas pelo código de 2002, cujo inicio de vigência se deu em 2003; e, isto porque os prazos prescricionais - em regra sofreram sensível diminuição, sendo o mais extenso deles (prescrição vintenária) substituído por prazo decenário, por exemplo. Dúvidas surgiram a respeito da contagem dos prazos a partir da vigência do novo ordenamento e, passados pouco mais de seis anos da vigência do código de 2002, algumas considerações ainda podem ser feitas, vez que há ações cujo lapso prescricional permanece regido pelo ordenamento anterior. Melhor explicando, o lapso prescricional da lei antiga prevalecerá sempre que, ao tempo do início da vigência da lei nova mais da metade dele tivesse transcorrido; ao passo que, caso menos da metade do prazo tenha passado, aplicar-se-á o estabelecido na nova lei, contado a partir de sua vigência. Importante notar que, tendo em vista a disposição do legislador reduzindo o prazo, deve sempre prevalecer contagem que a partir da vigência da nova norma não ultrapasse o prazo estabelecido por ela, sob pena de prevalecer o ilógico ${ }^{37}$. Neste sentido, também preconizam outros ordenamentos, como o alemão, nas palavras de Wilson de Souza Campos Batalha: se a lei nova reduz o prazo de prescrição ou decadência, há que se distinguir: a) se o prazo maior da lei antiga se escoar antes de findar o prazo menor estabelecido pela lei nova, adota-se o prazo estabelecido pela lei anterior; b) se o prazo menor da lei nova se consumar antes de terminado o prazo maior previsto pela lei anterior, aplica-se o prazo da lei nova, contando-se o prazo a partir da vigência desta. ${ }^{38}$

Como mencionado, o Código Civil estabelece como prazo para a prescrição ordinária o lapso temporal de dez anos (artigo 205), ficando eventual redução deste a cargo do legislador.

\footnotetext{
37 “o prazo da lei nova é contado a partir de sua vigência, mas não se despreza a fração já transcorrida antes dela. Assim, o prazo menor será aplicado, mas se antes de seu vencimento completar-se o prazo antigo (maior), este é que prevalecerá, pois não seria lógico que tendo a lei nova determinado à redução do prazo prescricional sua aplicação acabasse por proporcionar à parte um lapso ainda maior que o da lei velha". ROUBIER, Paul. Le doit transitoire (conflits des lois dans le temps). 2. Ed., Paris: Dalloz et Sirey, 1960, citado por THEODORO JÚNIOR, Humberto: Comentários ao novo Código Civil, vol. 3, t. 2., Rio de Janeiro, Forense, 2003.

${ }^{38}$ BATALHA, Wilson de Souza Campos: Lei de Introdução do Código Civil, São Paulo, Max Limonad, 1957, p.229.
} 


\subsection{Prescrição no Direito Penal.}

No campo penal a prescrição atinge o jus puniendi do Estado $^{39}$, limitando no tempo a capacidade do Poder Público de dar uma resposta àquele que violou a lei penal.

Mais uma vez busca a segurança jurídica, ao retirar do Estado a possibilidade de manter indefinidamente uma espada sobre a cabeça daquele que descumpriu suas normas.

A norma penal incriminadora cria para o Estado, que é seu único titular, o direito de punir abstrato, exigindo que os jurisdicionados não adotem certas condutas, descritas enquanto ilícitos penais. Praticado o ato a direito de punir - até então abstrato - passa a ser concreto, sendo classificado como pretensão punitiva, que ocorre antes do trânsito em julgado e é a exigência de que o poder-dever de punir do Estado subordine o direito de liberdade do cidadão. Porém o dever de punir não é ilimitado, sendo o due processo of Law, seu maior informador; ao final do processo, em havendo sentença condenatória irrecorrível, surge a pretensão executória do Estado, que a exemplo do jus punitionis ou puniendi também não é absoluta, e, portanto, estará sujeita à caducidade pela via prescricional. A prescrição é uma das balizas ao comportamento do Estado $^{40}$, cominando a perda da pretensão punitiva ou executória, face à passagem de certo lapso temporal.

Para a doutrina majoritária, a prescrição é um instituto de direito penal e não de processo penal, fazendo com que o dia do início do prazo seja computado na contagem, neste sentido pronunciam-se Cezar Roberto Bittencourt e Damásio Evangelista de Jesus.

A regra da prescritibilidade que encontra em direito penal exceções, advindas da Constituição Federal, regras - no dizer de Marco Antônio Marques da Silva - de "Direito Penal Constitucional", são os delitos explicitados nos incisos XLII e XLIV do artigo 5॰ da Constituição Federal, que tratam dos delitos de racismo e da a ação de grupos armados, que incluem o terrorismo, note-se que outros delitos podem ser acrescentados por tratados e convenções internacionais, mormente em função do parágrafo $3 \circ$ do artigo $5 \circ$ da $\mathrm{CF}$, acrescentado pela emenda constitucional 45 de dezembro de 2004.

\footnotetext{
${ }^{39}$ Ou o jus executionis, como será tratado em seguida.

${ }^{40} \mathrm{O}$ artigo 107 do Código Penal traz rol exemplificativo de causas extintivas de punibilidade.
} 
A teor do dito acerca da prescrição em Direito Civil, em Direito Penal, de há muito a prescrição é considerada matéria de ordem pública, devendo ser declarada de ofício pelo magistrado, conforme determina o artigo 61 do Código de Processo Penal. Entretanto, diferentemente do prescrito nas normas civis, em Direito Penal o lapso temporal não é fixo conforme o tipo de ação (no caso a espécie do delito), mas varia em função da pena cominada, em abstrato ou concretamente.

A pena, abstratamente considerada é a estabelecida pelo legislador no tipo penal; dentro do balizamento oferecido, o prazo prescricional será contado a partir do máximo da pena base ${ }^{41}$ que infrator poderá receber caso condenado ${ }^{42}$. A pena in concreto, por sua vez é a que resta imposta pelo magistrado ao caso concreto, após toda a dosimetria feita.

O prazo, conforme já mencionado, é - pela doutrina majoritária - de Direito Penal, sendo assim, o dia do início será computado, independentemente de qualquer fracionamento ${ }^{43}$, e tal data é a da ação ou omissão criminosa $^{44}$. O prazo prescricional será, em regra, interrompido em duas oportunidades, no recebimento da denúncia e na publicação da sentença condenatória. Em sede de julgamento pelo Tribunal Popular, acrescentar-se-ão dois momentos, a publicação da pronúncia e a confirmação da pronúncia.

Em sede de direito penal, dada a peculiaridade da prescrição, cujo lapso temporal é variável em função da diversidade entre a pena abstrata e concreta, interessante se tratar, ainda que superficialmente, da prescrição intercorrente e da prescrição retroativa. A primeira caracteriza-se enquanto não houver transitado em julgado a sentença para a acusação, isto é, o recurso impeditivo do princípio prescricional é o apelo da acusação que visa à agravação da pena privativa de liberdade aplicada pelo juiz. Enquanto não houver a decisão do recurso da acusação, correrá o prazo prescricional da pena máxima em abstrato; já a segunda, respaldada pela Súmula 146 do Supremo Tribunal Federal, ocorrerá sempre que houver trânsito em julgado para a acusação, e o seu

\footnotetext{
${ }^{41}$ A pena-base, em nosso sistema trifásico de Nelson Hungria, é entendida como a dosimetria inicial da pena a ser aplicada, devendo situar-se, necessariamente, dentro dos limites típicos, ou seja, entre o máximo e o mínimo previstos como pena abstrata para determinada conduta. Sobre ela incidirão, quando aplicáveis, as circunstâncias agravantes e atenuantes, bem como as causas de diminuição e aumento da pena.

42 A prescrição incidirá sobre a pena do delito da efetiva condenação, assim em caso de desclassificação, despreza-se o delito da denúncia para fins de cálculo do prazo.

${ }^{43}$ Não importará o horário da prática do delito, aquele dia será computado por inteiro.

${ }^{44} \mathrm{O}$ artigo 111 do Código Penal, traz os momentos possíveis para início da contagem do prazo.
} 
parâmetro será a pena in concreto, uma vez que o trânsito em julgado (para a acusação) torna aquela pena impassível de majoração; isto posto, já é conhecido o lapso prescricional máximo, que poderá ser aplicado, e sendo assim a prescrição da pretensão punitiva pode ser avaliada conforme tal parâmetro. Registre-se que as causas de interrupção serão as mesmas.

Após o trânsito em julgado da sentença, passa o jus puniendi para a fase executória, surgindo o jus executionis, fase em que o Estado imporá ao condenado o cumprimento da sanção. Neste momento existe apenas a pena concreta, que irá - por óbvio - ser utilizada para o cálculo da prescrição. Em se tratando de substituição de pena privativa de liberdade por pena restritiva de direitos, prevalecerá o lapso temporal de prescrição previsto para a primeira, o que também ocorrerá caso haja multa cumulativa ou alternativamente aplicada; caso esta seja a única sanção, prescreverá em dois anos.

Caso ao tempo do crime o agente tivesse menos de 21 anos ou mais de 70 ao tempo da sentença, o prazo prescricional reduzir-se-á à metade, conforme preceitua o artigo 115 do $\mathrm{CP}$; note-se que a idade ao tempo do crime não se relaciona com a maioridade civil, sendo irrelevante a alteração advinda com o Código Civil vigente, que reduziu a maioridade civil de 21 para 18 anos. A redução do lapso prescricional em função da idade do agente permanece inalterada.

Tal qual ocorre do Direito Civil, a prescrição do jus puniendi também está sujeita à suspensão e à interrupção de seu prazo; no primeiro caso o artigo 117 do Código Penal traz um rol taxativo de hipóteses, já no segundo o artigo 116 do mesmo codex o rol é exemplificativo (a Lei 9.099/95, por exemplo, traz hipótese outra de suspensão do prazo prescricional).

Portanto, no campo penal a regra, mais uma vez, é a prescritibilidade, no entanto existem exceções advindas da própria Constituição da República, não há prescrição nos crimes de racismo (art. 5, XLII regulamentado pela Lei $\mathrm{n}^{\mathrm{o}}$ 7.716, de 5 de janeiro de 1989, com alterações da Lei n. 9.459, de 15 de maio de 1997) e aos referentes à ação de grupos armados, civis ou militares, contra a ordem constitucional e o Estado Democrático (art. 5 XLIV).

Nas constituições brasileiras - na relação entre o direito penal e a perenidade - de um lado sempre prevaleceu a regra da imprescritibilidade e de outro a inexistência de prisão perpétua. 


\subsection{Prescrição no Direito Administrativo.}

A prescrição no Direito Administrativo pode ser analisada sob três vertentes principais: prazo para recorrer de decisão administrativa; prazo para que a Administração reveja seus atos e o prazo para a aplicação de penalidades administrativas. Que, repise-se, é o que mais de perto interessa a este estudo. E, uma vez mais lembramos que seu fundamento é a inércia do titular do direito no exercício deste.

Tal qual foi dito com relação ao Direito Penal, a prescrição é tema de Direito Administrativo, e não de processo; Direito Processual; sendo assim, a competência para legislar a respeito do tema é da mesma pessoa sob cuja guarida estiver a respectiva matéria, não podendo se falar em competência exclusiva da União, por exemplo.

E é no exercício do poder disciplinar que se observa mais comumente o fenômeno da prescrição no âmbito da Administração, um obstáculo que se coloca para evitar que o Estado tenha indefinidamente o direito de aplicar sanções em face daqueles que com ele possuem relação jurídica que os sujeite ao poder disciplinar.

De se destacar que, muito embora parte da doutrina imagine os prazos prescricionais enquanto prazos decadenciais ${ }^{45}$, tal visão não procede. $\mathrm{O}$ fundamento de tais juristas é o seguinte:

A distinção entre prescrição e decadência é, em linhas gerais, e nas palavras de Rafael Munhoz de $\mathrm{Mello}^{46}$, que enquanto a primeira "atinge direitos subjetivos que correspondem a uma prestação da outra parte da relação jurídica (fazer algo, não fazer, dar). Ofendido o direito, com o descumprimento da prestação, nasce para seu titular a pretensão, entendida justamente como poder de exigir de outrem uma prestação. A lei estabelece prazo para o exercício da pretensão, que, uma vez ultrapassado, impede que o titular do direito exija da outra parte a prestação devida. Não há, aqui, a extinção do direito, mas sim da pretensão - o que significa dizer que a prestação devida deixa de ser exigível. Muito embora se torne inexigível, o direito à prestação não é extinto pelo decurso do prazo, razão pela qual o ordenamento jurídico tutela e reconhece seu cumprimento espontâneo (por exemplo, o pagamento de dívida prescrita prevista no art. 882 do Código Civil).

\footnotetext{
${ }^{45}$ Almiro do Couto e Silva, Celso Antonio Bandeira de Mello, Rafael Munhoz de Mello e Weida Zancaner são exemplos.

${ }^{46}$ Princípios constitucionais de Direito Administrativo sancionador, São Paulo, Malheiros, 2007, p. 253.
} 
Há outras situações em que o ordenamento jurídico estabelece prazo não para o exercício da pretensão, mas sim para o exercício de algum direito. Não se trata mais da exigibilidade de uma prestação que foi descumprida, mas, sim, da possibilidade de exercer um direito ou um poder que vai produzir efeitos na esfera jurídica de outrem. Encerrado o prazo extingue-se o direito, que já não mais pode ser exercido. Opera-se, então, a decadência ou caducidade.

Assim entendidos os institutos, fica evidente que a perda do poder punitivo da Administração Pública não decorre de prescrição. Não se trata de extinção da exigibilidade de uma prestação de fazer, não fazer ou dar, mas, sim, da extinção de um poder, que já não pode mais ser exercido. Trata-se - nas palavras de Celso Antônio Bandeira de Mello - da "perda da possibilidade de a Administração prover sobre determinada matéria em decorrência do transcurso do prazo", donde configura-se situação de decadência ${ }^{47}$.

Diante da explicação supra - em que pese o respeito pela conclusão, pelos mesmos fundamentos outra deverá ser a solução. Em verdade trata-se de prescrição, uma vez que o direito ofendido pela falta disciplinar permanece, é insuscetível de prescrição $^{48}$, em verdade o que perece é a ação disciplinar (inquérito administrativo ou sindicância) que o Estado teria que deflagrar para punir o indivíduo. Note-se que tal ação, em face do princípio do devido processo legal, é imperativa para que haja punição.

Neste diapasão, não há de se falar em decadência, mas em prazo prescricional. Tal entendimento é respaldado pela doutrina de Brandão Cavalcanti, de Marcello Caetano e de Edmir Netto de Araújo, entre outros.

O processo administrativo, repise-se obrigatório, será utilizado sempre que houver infração ao ordenamento; e, tal afronta poderá ser tanto um ilícito administrativo puro quanto um ilícito também punível na esfera penal.

A caracterização da espécie de ilícito é importante para que sejam estabelecidas as regras atinentes ao cômputo do prazo prescricional; afinal, se a prescritibilidade é a regra, importante saber quando efetivamente se dará a extinção da capacidade do Estado infligir pena ao infrator. Pois, a finalidade do procedimento administrativo não é outra que não o reconhecimento ou declaração de um direito, mas

${ }^{47}$ MELLO, Rafael Munhoz de: Princípios constitucionais de Direito Administrativo Sancionador - São Paulo, Malheiros, 2007.

${ }^{48}$ CRETELLA JÚNIOR, José: Prática do Processo Administrativo, 6ª ed. São Paulo, RT, 2008. 
direito que pertence à Administração, ou seja, o de sancionar as faltas cometidas por seus agentes ou pelos particulares que não respeitarem preceitos cuja aplicação cabia à Administração fiscalizar ${ }^{49}$.

A ação cuja prescrição administrativa impede é uma ação interna, no campo administrativo, mas pode se dar no campo penal, quando a conduta também constituir crime; sendo assim o Estado perde a capacidade de punir o infrator, em face da passagem do tempo, o que não significa a prescrição administrativa da falta em si. A inércia estatal caracteriza a impossibilidade da instauração do processo administrativo, que nada mais é que a ação apta a promover a punição daquele que descumpriu a norma. Estamos tratando de prescrição administrativa que, dada a independência das instâncias, deve pressupor a existência de uma ação administrativa apta à defesa de um direito, no caso o direito do Estado de punir, porque ela significa a perda da respectiva ação, por inércia do seu titular. Assim, repisamos a adequação do termo prescrição administrativa.

Em resumo, se vigora no ordenamento pátrio $o$ princípio da prescritibilidade da pretensão punitiva da Administração, tal instituto é de prescrição administrativa e não de decadência.

Trata-se de conclusão respaldada no parecer de diversos doutrinadores, bem como no próprio texto constitucional que no parágrafo $5^{\circ}$, do artigo 37, determinou a fixação, mediante lei, de prazos de prescrição para ilícitos praticados por qualquer agente, servidor ou não, que causem prejuízos ao erário, ressalvadas as respectivas ações de ressarcimento.

Com relação ao prazo, diversos diplomas legais adotaram a prescrição quinquenal como regra; tradição inaugurada com o Decreto n॰ 20.910, de $1932^{50}$ e que permanece até os dias atuais em exemplos que vão desde o Código Tributário Nacional até o Estatuto dos Funcionários Públicos Civis da União, mas isto não significa que na ausência de previsão legislativa prevalecerá o prazo de cinco anos, a doutrina e a jurisprudência divergem, como adiante será visto.

Para os atos nulos e anuláveis, em que pese a Lei n 9.784, de 1999, que disciplina o processo administrativo no âmbito da Administração Pública Federal e fixa o prazo de cinco anos para a anulação de atos dos quais decorram efeitos favoráveis aos destinatários, a doutrina divergente no que concerne à aplicação de

\footnotetext{
${ }^{49}$ NASSAR, Elody: Prescriçao na Administração Pública, São Paulo, Saraiva, 2004.

${ }^{50}$ Que previa tal prazo nas ações contra o Estado.
} 
tal prazo aos atos nulos e anuláveis, surge mais uma questão polêmica entre os doutrinadores, que será abordada.

Ainda com relação ao processo administrativo, mormente o disciplinar, diverge a doutrina e a jurisprudência acerca do dies a quo para a contagem do prazo, e não se trata de discussão de menor relevância, pois há posicionamentos que levariam à seara da imprescritibilidade.

Em se tratando de Direito Administrativo Disciplinar, a prescrição é regulada - como mencionado - pelo ente que possui legitimidade para legislar a respeito do estatuto que regerá os servidores, desta forma trata-se de competência concorrente dos entes da federação. Assim os três níveis da Administração poderão adotar tratamento diferenciado para a questão. Ainda com relação ao processo disciplinar, o ilícito pode ser puramente administrativo, ou criminal, caso em que se aplicarão as disposições do Código Penal, aspecto comum à legislação pertinente ao tema tanto no Município, quanto no Estado de São Paulo e na União, conforme será descrito.

Os prazos prescricionais no Brasil, em geral, são superiores aos de outros países. Na França, por exemplo, a regra é a prescrição quadrienal. $\mathrm{Na}$ Itália, a média é de três anos.

Os matizes que envolvem o tema da prescrição administrativa são analisados a seguir. 


\section{TERCEIRA PARTE - PROCESSO ADMINISTRATIVO}

\section{Processo administrativo.}

\subsection{Processo e procedimento.}

Em que pesem as distinções efetuadas pela doutrina a respeito de processo e procedimento, ontologicamente não são institutos diversos, ao contrário, possuem a mesma origem latina e, portanto, o mesmo significado na raiz.

Tal ligação, entretanto, não faz com que sejam expressões sinônimas, como alguns poderiam pensar; e grande parte da confusão e respeito do tema tem origem na falta de precisão de linguagem utilizada cotidianamente, a própria lei nem sempre segue o rigor técnico que deveria. Muitas vezes se fala em "consultar o processo", quando a materialidade dos documentos forma os autos. O processo necessita da existência de lide, da pretensão resistida que formará o contraditório. Melhor seria se todos procurassem seguir o rigor técnico de linguagem do Código de Processo Civil.

Como foi dito o procedimento é a exteriorização do processo, o rito $^{51}$ que ele segue. $\mathrm{O}$ processo já recebeu diversas definições, mas em seu núcleo fundamental sempre está a busca pela justiça, a eliminação dos conflitos o estabelecimento de uma situação de paz social. O processo não prescinde do contraditório, portanto. Na visão de Ada Pellegrini Grinover, Antônio Carlos de Araújo Cintra e Cândido Rangel Dinamarco ${ }^{52}$, processo é conceito que transcende ao direito processual. Sendo instrumento para o legítimo exercício do poder, ele está presente em todas as atividades estatais (processo administrativo, legislativo) e mesmo não estatais (processos disciplinares dos partidos políticos ou associações, processos das sociedades mercantis para aumento de capital etc...).

Em que pese à idéia do processo estar adstrito à solução da lide em sede jurisdicional, é inegável a existência de processos administrativos, sem perder o rigor da linguagem; pois, em havendo todos os elementos do instituto ele está caracterizado.

\footnotetext{
${ }^{51}$ Ou curso processual.

${ }^{52}$ Teoria Geral do Processo, 24 ${ }^{\mathrm{a}}$, São Paulo, Malheiros, 2008.
} 
Em síntese, o procedimento pode ser entendido enquanto o rito a ser seguido, e sempre que tal rito for qualificado por uma litigância sobre a qual recai o contraditório, então teremos a figura do processo. Sendo assim o processo é um procedimento qualificado pela existência de contraditório. O processo, assim, não existe sem o procedimento que, por sua vez, pode prescindir do processo para se caracterizar.

Com relação à natureza jurídica do processo, esta já foi vista como: contrato (séculos XVIII e XIX), quase-contrato (século XIX), relação jurídica (século XIX e XX, a mais aceita até hoje entre os processualistas brasileiros), situação jurídica (século XX) e, mais recentemente, processo enquanto procedimento em contraditório.

A natureza jurídica contratual tinha o mesmo sentido da doutrina política então vigente do Contrato Social consagrada por Jean-Jacques Rousseau; nos dias atuais poderia mutatis mutandis ser aplicada ao juízo arbitral, que possui como característica principal a livre escolha do julgador da lide, a cuja decisão também por convenção - os litigantes se sujeitarão. A teoria do quase contrato foi, desde seu nascimento, muito criticada, pois já era considerada insuficiente para explicar a natureza do processo, contentando-se em excluir a natureza contratual.

Já a teoria da relação jurídica, criada e desenvolvida por Oskar Von Bülow em sua obra "Teoria dos pressupostos processuais e das exceções dilatórias" de 1868, na qual aduz ser o direito processual um ramo autônomo do Direito. Foi um divisor de águas. Muito embora já houvesse desde o direito romano a idéia de uma relação jurídica entre as partes e o juiz, foi Büllow que a sistematizou, demonstrando os elementos identificadores da relação jurídica tendo como sujeitos juiz, autor e réu, como objeto a prestação jurisdicional e como pressupostos: a propositura da ação, a capacidade de ser parte e o reconhecimento de um Estado soberano com poderes jurisdicionais. Foram utilizadas como premissas além da autonomia do processo a relação de direito público entre o Estado e os litigantes; a grande crítica ficou por conta da teoria desenvolvida ter se atido ao direito privado, pecado que não tira o mérito. Como mencionado trata-se da teoria com maior aceitação entre os juristas brasileiros. 
Pelas mãos de James Goldschmidt surge uma nova teoria indicando que o processo é uma situação jurídica; mesmo sofrendo muitas críticas, o estudo traz diversos conceitos que foram fundamentais ao desenvolvimento do direito processual, como, por exemplo, a relação funcional do juiz com o Estado (isentando a pessoa física do juiz de obrigações com as partes). A doutrina de Goldschmidt foi assim resumida por Ada Pellegrini Grinover, Antônio Carlos de Araújo Cintra e Cândido Rangel Dinamarco

"quando o direito assume uma condição dinâmica (o que se dá através do processo), opera-se nele uma mutação estrutural: aquilo que, numa visão estática, era um direito subjetivo, agora se degrada em meras possibilidades (de praticar atos para que o direito seja reconhecido), expectativas (de obter esse reconhecimento), perspectivas (de uma sentença desfavorável) e ônus (encargo de praticar certos atos, cedendo a imperativos ou impulsos do próprio interesse, para evitar a sentença desfavorável)... Em resumo, onde havia o direito há agora meras chances (expressão utilizada por Goldschmidt para englobar todas as possibilidades, expectativas, perspectivas e ônus)". ${ }^{53}$

A teoria se mostrou insuficiente por dois motivos principais: partir dos defeitos do processo e referir-se a uma situação jurídica e não a um complexo de situações que em verdade envolvem o processo. Porém, ainda que rejeitada, a teoria indubitavelmente trouxe conceitos de direito processual (como ônus e sujeição) fundamentais ao desenvolvimento e na modernização do processo civil.

Ainda no século XX a teoria do processo enquanto relação jurídica mereceu críticas, mormente advindas da modernidade que o contraditório passe a elemento do processo, surgindo na Itália uma nova vertente que dá ao processo a natureza jurídica de "procedimento qualificado pelo contraditório".

De fato a dialética do contraditório de há muito habita o processo, prova disto é o brocardo romano audiatur et altera pars sugerindo que os argumentos de uma parte tenham que ser contra-argumentados pela outra. Posteriormente a

${ }^{53}$ Teoria Geral do Processo, 24 ${ }^{\mathrm{a}}$ ed São Paulo, Malheiros, 2008. 
isto teremos um juiz que dará uma decisão fundamentada, que se distancia da arbitrariedade, em face da participação das partes.

Tanto a Declaração Universal dos Direitos Humanos, quanto a Convenção Americana de Direitos do Homem, o conhecido Pacto de San Jose da Costa Rica consagraram não apenas o direito ao conhecimento das alegações da outra parte, como a possibilidade de reagir a eles, antes do julgamento dos litígios. Hoje a maior parte das constituições prevê o contraditório enquanto garantia do Estado Democrático.

Diante disso, nada mais adequado que o contraditório seja elemento estrutural do processo, cuja fundamentação da decisão também será condição sine qua non para sua legitimidade em uma democracia.

E, conforme dito, mais que o conhecimento dos atos da outra parte, o contraditório permite que haja uma reação, contra-argumentando o suscitado, com o fito de dar elementos ao Estado para que proceda ao julgamento com o maior número de elementos possíveis o que, em tese, redundará em um provimento adequado.

Ao final o contraditório é a bilateridade de todos os atos do processo, seja com relação à informação ou à possibilidade de reação.

Em que pese à adequação e importância da presente teoria, até mesmo pela sua aceitação face sua concordância com o tempo atual, sua aplicação não se mostra incompatível com a doutrina do processo enquanto relação jurídica, sendo a ela complementar.

Com relação ao procedimento, não há divergências entre os processualistas, por mais que existam definições diversas (como as de Oskar Von Bülow, de Francesco Carnelutti, de Grinover, Cintra e Dinamarco) todas possuem um traço que as aproxima que é tratar o procedimento como exteriorização do processo.

Ou seja, o procedimento - que se caracteriza como uma série de atos concatenados de maneira ordenada (por previsão legal); tais atos são interdependentes, pois a finalidade os une. O processo será instaurado, desenvolvido e terminado por meio do procedimento. 
Os atos processuais não podem prescindir do procedimento, que traz lógica em seu bojo de forma que cada ato possui seu momento oportuno e uma relação de interdependência segundo a qual os atos posteriores vinculamse aos anteriores. A legalidade de forma de tais atos visa proteger o Estado Democrático, na medida em que garante o devido processo legal.

Tal qual a prescrição, mais uma vez estamos diante de um instituto cujo fundamento se dá na segurança jurídica, condição essencial para a paz social que é o objetivo maior do Estado.

$\mathrm{O}$ ordenamento processual pátrio prevê tanto o impulso oficial, quanto a iniciativa das partes, bem como uma série de procedimentos (ritos processuais) cuja aplicação se dará de acordo com a relação jurídica material entre as partes.

Basicamente os procedimentos previstos no Código de Processo Civil são o comum e o especial, o primeiro subdividido entre ordinário e sumário, o segundo - por sua vez - divide-se entre os procedimentos de jurisdição voluntária e de jurisdição contenciosa.

O procedimento comum ordinário é residual, pois sempre que não for aplicável um procedimento especial, será adequado o procedimento comum e, dentro deste, mais uma vez se aplica o raciocínio da exclusão, sempre que não for possível o rito sumário será caso de rito ordinário. Há, inclusive, doutrinadores que por conta de tais particularidades - colocam o procedimento comum sumário na seara dos procedimentos especiais, neste sentido sustenta José Carlos Barbosa Moreira ${ }^{54}$.

\subsection{Processo administrativo.}

A existência de processo administrativo é voz comum na doutrina tendo os administrativistas se dedicado cada vez mais ao seu estudo.

\footnotetext{
${ }^{54}$ MOREIRA, José Carlos Barbosa: Comentários ao Código de Processo Civil vol. V, São Paulo, $13^{\mathrm{a}}$ ed Forense, 2006.
} 
$\mathrm{Na}$ visão de José Cretella Júnior ${ }^{55}$ o processo administrativo, na prática das repartições e dos Tribunais, é formado por alguns princípios teóricos e por precisas regras do direito positivo, constitucionais, legais e estatutárias.

O processo administrativo tal qual ocorre com todos os institutos não pode se dissociar a teoria da prática, sendo como verso e anverso da mesma moeda; ele é previsto desde a Carta Magna, junto aos direitos e garantias individuais (artigo $5^{\circ}$, LV da Constituição Federal) sendo regulado por Lei Federal específica (Lei 9.784, de 29 de janeiro 1999).

Saliente-se que a supra mencionada lei não regulamenta todo e qualquer processo administrativo, mas apenas e tão somente os de competência da União sendo aplicável, conforme seu próprio texto, apenas subsidiariamente aos processos administrativos especificamente considerados. ${ }^{56}$

A existência do processo administrativo dá maior segurança aos administrados, traduzindo-se no fim das contas em um instrumento útil para o Estado que ganha confiabilidade perante os administrados em uma atuação transparente, com fulcro nos princípios constitucionais previstos no artigo 37 da Constituição.

A ausência de legislação federal regulamentando o processo administrativo (anteriormente taxada como praticamente "escandalosa" pelos doutrinadores $^{57}$ ) foi solucionada pela mencionada Lei 9.784/99, que conforme dito tem caráter subsidiário. É que o processo administrativo não é matéria jurisdicional - em um sistema de jurisdição una como o nosso - e as regras de direito processual são, conforme sabido editadas com exclusividade pela União ${ }^{58}$ e se aplicam - por óbvio - a todos os entes da federação; já no processo administrativo (que conforme mencionado possui as características de processo enquanto relação jurídica qualificada pelo contraditório) a competência legislativa é comum a todas as esferas.

Assim, dada a característica da especialidade da legislação produzida pelo ente federado para regulamentar os processos administrativos em seu âmbito de atuação, fica cristalina a subsidiariedade da norma federal citada.

O processo administrativo terá como finalidade, que é também consequência lógica de sua aplicação, dar maiores garantias aos administrados e

\footnotetext{
${ }^{55}$ CRETELLA JÚNIOR, José: Prática do processo administrativo 6 ${ }^{\mathrm{a}}$ ed, São Paulo, RT, 2008.

${ }^{56}$ Artigo 69 da Lei 9.784/99.

${ }^{57}$ Neste sentido, Sérgio Ferraz e Adilson de Abreu Dallari, Processo administrativo, $2^{\mathrm{a}}$ ed, São Paulo, Malheiros, 2007.

${ }^{58}$ Constituição Federal, artigo 22, I.
} 
mais eficiência para a Administração Pública afinal o processo propicia maior controle tanto pra a administração internamente quanto perante os administrados.

$\mathrm{O}$ afastamento do processo administrativo do direito processual jurisdicional, verificado por José Cretella Junior ${ }^{59}$ não o descaracteriza enquanto processo, tampouco impede, desclassifica ou repele as definições feitas pelos autores; até mesmo porque a noção de processo é mais ampla que a própria função jurisdicional $^{60}$.

Desta forma, considerando o processo em sentido amplo enquanto gênero, surgem duas espécies o processo jurisdicional e o processo administrativo ambos com características comuns, porém com diferenças suficientes para não poder ser considerado o processo administrativo enquanto ramo do direito processual, mas sim como espécie da categoria jurídica do processo enquanto instituto, na qual se coloca ao lado dos processos judiciais.

Os processos judiciais serão regrados pela legislação produzida exclusivamente pela União e se subdividem em civis, penais e trabalhistas; os processos administrativos terão seu regramento próprio, com aplicação subsidiária de normas gerais editadas pela União.

Repise-se, o fato do processo administrativo não estar inserido no direito processual não o descaracteriza enquanto processo.

E o processo administrativo terá - como de fato tem fundamentação constitucional, características e institutos diferenciados como é o caso da prescrição administrativa.

\subsection{Modalidades.}

Como dito o processo administrativo possui base constitucional bem como uma Lei Federal de aplicação subsidiária, entretanto, tal subsidiariedade, por óbvio, não significa sujeição irrestrita aos ordenamentos específicos. Em verdade a Lei Federal geral relativa aos processos administrativos traduz os comandos constitucionais aplicáveis à espécie, não podendo ser contrariada pelos regramentos dos entes da federação.

\footnotetext{
${ }^{59}$ Conforme colocação introduzida na última edição $\left(6^{\mathrm{a}}, 2008\right)$ da obra Prática de processo administrativo.
}

${ }^{60}$ RIVERO, Jean; WALINE, Jean: Droit administratif, 19a ed Dalloz, Paris, 2002. 
Sendo assim, o processo administrativo é uno, sendo possível a existência de processos administrativos com procedimentos especiais, em função de seu objeto, como é o caso do processo administrativo disciplinar.

Entretanto, para fins didáticos, relevante a classificação sugerida por Odete Medauar $^{61}$ que situa os seguintes processos administrativos:

1 processos administrativos em que há controvérsias, conflitos de interesses; subdivididos em: processos administrativos de gestão (como concursos públicos e concursos de acesso ou promoção); processos administrativos de outorga (como licenciamento ambiental e registro de marcas e patentes); processos administrativos de verificação ou determinação (lançamento tributário e consulta fiscal); processos administrativos de revisão (como recursos administrativos, por exemplo);

2 processos administrativos em que há acusados, denominados "processos disciplinares"; subdivididos em: internos (como os processos disciplinares em face de servidores e alunos de estabelecimentos públicos) e externos (que visam a apurar infrações, cometidas por administrados que não integram a organização administrativa, como: sanções decorrentes do poder de polícia, da administração fiscal, aplicação de penalidades a particulares que celebram contrato com a Administração).

Tal classificação merece menção, em que pesem as críticas feitas.

A inexistência de divisão no processo administrativo é respaldada pela própria legislação, neste sentido veja-se a Lei 10.177/99 do Estado de São Paulo acerca dos processos administrativos ${ }^{62}$ que expressamente diz em sua ementa tratar do processo administrativo no âmbito da Administração Pública Estadual e, em seu corpo, refere-se a procedimentos diversos, demonstrando haver unidade do processo e pluralidade de procedimento. Refere-se, acertadamente, ainda tal regramento a necessidade de atentar à eventual legislação específica, uma vez que possui caráter subsidiário.

\footnotetext{
${ }^{61}$ MEDAUAR, Odete: A processualidade no Direito Administrativo, São Paulo, RT, 1993.

${ }^{62}$ Adilson Abreu Dallari, Edmir Netto de Araújo e Sérgio Ferraz estão entre os doutrinadores que elogiaram tal diploma legal.
} 


\subsection{Princípios.}

O mais importante princípio que rege o processo administrativo é o devido processo legal; pois, no final das contas, dele decorre a própria positividade dos demais ditames cujo seguimento é obrigatório, ou cuja conduta em desacordo é vedada. Na visão de Carmem Lúcia Antunes Rocha ${ }^{63}$, tal princípio é "vinculador de todo procedimento administrativo, compreende um conjunto de elementos jurídicos garantidores de direitos fundamentais quando ameaçados, lesados ou simplesmente questionados, tais como o direito à ampla defesa, ao contraditório, ao juízo objetivo e devidamente motivado, atuando como instrumento legitimador da ação administrativa".

Sem o due processo of Law seria possível fazer tabula rasa dos demais colocando por terra todo o sistema processual. Basta dizer que a própria segurança jurídica, classificada por Adilson Abreu Dallari enquanto um superprincípio de Teoria Geral do Direito, garantida é pela efetividade do devido processo legal e a ele está umbilicalmente ligada.

Desde logo se deve dizer que o rol de princípios previstos na legislação deve ser visto como exemplificativo, até mesmo pela utilidade que pode advir da aplicação de um princípio não previsto expressamente, mas que implicitamente deve ser tido como presente e aplicável ao processo administrativo.

Sérgio Ferraz e Adilson Abreu Dallari em seu Processo Administrativo ${ }^{64}$ elencam e analisam os seguintes princípios aplicáveis ao processo administrativo: igualdade; legalidade; finalidade; motivação; razoabilidade; proporcionalidade; moralidade; ampla defesa; contraditório; segurança jurídica; interesse público; eficiência; informalidade; boa-fé; publicidade; oficialidade; verdade material e duplo grau de jurisdição administrativa.

\subsection{Fases.}

Quatro são as fases identificáveis nos processos administrativos, a saber: inicial ou introdutória, instrutória, decisória e recursal. Todas as

\footnotetext{
${ }^{63}$ Revista de Informação Legislativa, out/dez, 1997, Brasília, ano 34, n 136, cuja leitura recomenda-se para aprofundamento no tema.

${ }^{64} 2^{\mathrm{a}}$ ed, São Paulo, Malheiros, 2007.
} 
fases do processo administrativo devem estar previstas sob pena de nulidade, no entanto, a fase recursal nem sempre será exercitada.

A fase inicial se dá na instauração do processo e nela são realizados atos pertinentes à verificação da peça deflagradora, que poderá ter diversas formas. A iniciativa poderá ser de ofício ou por intermédio de requerimento do interessado, no exercício do direito de petição. Nos dois casos os elementos formais para a instauração serão analisados sendo imprescindível o endereçamento, a identificação do requerente ou da autoridade expedidora do ato, a exposição nítida dos fatos ensejadores do pedido (ou demonstração documental dos fatos), descrição do pedido e seus fundamentos e a data e assinatura do requerente ou seu representante.

$\mathrm{Na}$ fase inicial deve ser verificada a legitimidade do interessado e a competência do órgão administrativo, inclusive com a verificação de casos de impedimentos e suspeição.

Como dito a única fase passível de inaplicabilidade é a recursal - muito embora sua previsão seja imprescindível - repise-se o assunto para que não haja dúvida a respeito da aplicação da chamada verdade sabida procedimento que face a consagração do contraditório e da amplitude de defesa não mais se mostra compatível com o processo administrativo brasileiro.

Dito isto, passemos a fase instrutória; deflagrado o processo administrativo e tomadas as providências referidas na fase anterior inicia-se a instrução que, em suma, é a fase na qual serão produzidas as provas, exercido o direito de contraditório e de defesa, em sentido amplo; permitida a realização de diligências, perícias, solicitação de pareceres; em última análise todo e qualquer meio lícito de prova deverá ser admitido. A instrução, cerne do processo administrativo, culmina com o relatório sumariando todo o ocorrido nos autos e por fim propondo - justificadamente e demonstrando as normas aplicáveis ao caso concreto - uma decisão.

A fase decisória é o objetivo maior do processo administrativo e um dever da Administração. A decisão deverá ser fundamentada e abrangente, com relação aos pedidos feitos e os fatos apurados, não podendo distanciar-se de qualquer deles; outrossim, face aos princípios consolidados pelo ordenamento na fase decisória deve ser analisada a regularidade formal do processo.

Em termos estruturais deve primar o ato decisório pela precisão técnica e clareza; sendo consubstanciada em três tópicos: relatório, fundamentação e parte dispositiva. No relatório estará presente uma sucinta descrição do 
ocorrido nos autos, sem qualquer juízo de valor acerca desta; a fundamentação, é condição sem a qual não há validade da decisão, deve ser clara e precisa - mas não prolixa - pois a maior extensão em nada contribui para a precisão técnica. A fundamentação deverá ser suficiente para demonstrar as razões de convencimento do julgador e aptas a persuadir outros a chegarem a tal convicção. Por derradeiro, a parte dispositiva, é decorrência lógica das fases anteriores e nela o julgador interpreta a lei transpondo a vontade desta ao caso concreto, dando fim ao litígio em nome do Estado, declarando a vontade deste, em caráter imperativo.

Com relação à fase recursal, esta não é obrigatória até porque a decisão pode ser acatada por todos os interessados - em que pese à previsão constitucional do duplo grau tanto para o processo jurisdicional quanto ao administrativo, é que o preceito constitucional refere-se à impossibilidade de exclusão da fase recursal, mas não impõe a obrigatoriedade de seu exercício. O recurso será fundamentado na inconsistência de uma das fases anteriores e é uma faculdade do inconformado.

Presentes na fase recursal tanto os recursos propriamente ditos, endereçados em regra para o órgão ou autoridade imediatamente superior àquela que decidiu; quanto os pedidos de reconsideração, feitos para a mesma autoridade que exarou a decisão e, por derradeiro, as revisões - fundamentadas no surgimento de fatos ou provas novas que tornem a decisão inconsistente, justificando sua modificação.

De se salientar que todas as fases são de previsão obrigatória, sem possibilidade de supressão, sendo o exercício da fase recursal facultativo. No entanto, excepcionalmente, é possível o arquivamento simples.

O arquivamento sem conclusão se dará exclusivamente na hipótese falta de apresentação pelo particular - quando este for o único interessado no desfecho do processo - de documento ou dado necessário à apreciação do pedido, desde que tal documento ou dado não esteja em poder da Administração. Note-se que todas as condições deverão estar presentes para o simples arquivamento, mormente a falta de interesse público no deslinde do processo.

Já a extinção do feito, com ou sem julgamento do mérito, importa na existência das fases processuais já descritas. São causas de extinção sem o julgamento do mérito a desistência, a renúncia, e a impossibilidade superveniente (de fato ou jurídica) do objeto ou finalidade do processo. Enquanto as causas extintivas que importam no julgamento do mérito são a prescrição e a decadência. 


\section{Processo administrativo disciplinar.}

\subsection{Notas introdutórias}

O processo administrativo disciplinar é ramo do processo administrativo que visa apurar a responsabilidade pelo ilícito administrativo, seja ele disciplinar ou funcional. Conforme exposto anteriormente, os casos de responsabilidade administrativa funcional existem quando a falta não tiver vinculação com a relação hierárquica, mas apenas às suas funções e atribuições. Já a responsabilidade disciplinar, é oriunda de falta que esteja relacionada com o poder hierárquico.

Seja qual for o caso, estar-se-á diante de um ilícito administrativo, apurável por intermédio do processo administrativo disciplinar.

Os ilícitos administrativos, por sua vez, podem ser classificados enquanto ilícitos administrativos puros e ilícitos administrativos penais. Os primeiros dizem respeito às quebras da ordem jurídica no âmbito administrativo e os segundos ocorrem quando a perturbação também for classificada enquanto ilícito penal (crime ou contravenção).

Mesclando-se as classificações pode ser traçado o seguinte quadro correspondente ao campo de atuação do processo administrativo disciplinar:

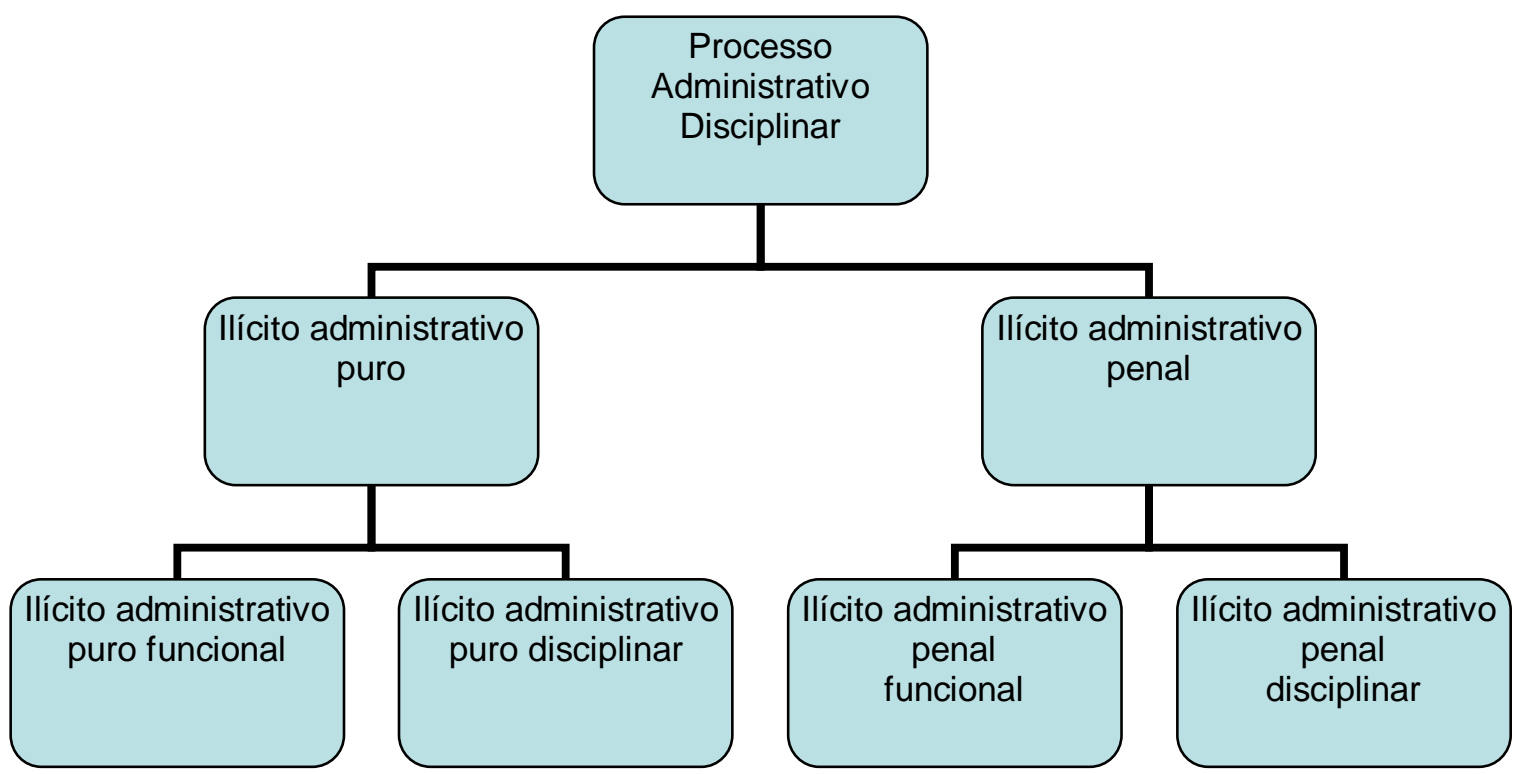


Assim o processo administrativo disciplinar irá apurar todos os ilícitos administrativos, sejam eles puros ou penais.

O poder disciplinar da Administração Pública, em sentido amplo, é exercido com o objetivo manter a ordem, estabelecida no Estado por meio do ordenamento jurídico; sua origem e razão de ser estão no interesse e na necessidade de aperfeiçoamento progressivo do serviço público.

Não é de se olvidar que na o poder disciplinar é classificado enquanto poder-dever, uma vez que não há discricionariedade ao superior hierárquico para a apuração, inclusive sujeitando eventual omissão à sanção.

Entretanto tal apuração seguirá o due process of Law que, como dito anteriormente não é privativo do direito processual, mas inerente a todo processo, jurisdicional ou administrativo, em um Estado democrático; o Estado-Juiz não se manifesta apenas por intermédio do poder judiciário; como é sabido as três funções estatais são realizadas pelos três poderes, de sorte que o processo administrativo estará sempre presente, mormente o processo administrativo disciplinar, essencial para o controle da Administração, seja punindo servidores faltosos, seja apurando condutas suspeitas de ilicitude.

O próprio Estado democrático só existe se mantenedor e mantido em seu bojo por instituições respeitáveis que possam dar efetivas garantias aos administrados, prontos a aplaudir a aplicação correta da lei.

O processo administrativo disciplinar visa, em última análise, a apuração de infração administrativa elencada no estatuto funcional específico, pois como dito a competência legislativa é comum aos entes federativos.

A ele devem ser aplicados - por força de norma cogente oriunda da Constituição Federal, os princípios da ampla defesa e do contraditório, sendo absolutamente rechaçada toda e qualquer menção à verdade sabida, como mais adiante será tratado.

Em que pese à competência legislativa comum, as normas de lei federal geral devem ser observadas pelos entes da federação, vez que são trazem em seu bojo o arcabouço principiológico constitucional aplicável.

Em resumo a aplicação subsidiária da norma federal não significa um distanciamento desta, ao contrário, ela será o eixo norteador das normatizações específicas, realizadas pelos entes federativos, que com ela devem guardar simetria. 
A regulamentação distancia o Estado do arbítrio, ao mesmo tempo em que o aproxima da legalidade; se este está absolutamente atrelado aos seus objetivos, mormente o bem comum, que é ligado à paz social e esta à segurança jurídica, não há como o Estado ser alheio à prescrição.

\subsection{Jus puniendi.}

O exercício do jus puniendi é o elemento fundamental do processo administrativo disciplinar e deve ser feito absolutamente balizado pela previsão legal, sob pena de prosperar a arbitrariedade e o abuso de poder.

O direito de punir consiste no poder genérico e impessoal de sancionar aquele que tenha cometido um ilícito; o jus puniendi nasce para o Estado, portanto, no momento em que o ilícito é praticado; seja ele civil, penal, ou administrativo.

Contrapõe-se ao direito de punir, ou a ele é inerente, o direito de defesa, amparado por princípios como o da presunção de inocência, por exemplo. O Estado então solucionará o litígio, sempre fundamentado no devido processo legal.

A solução do conflito, qualquer que seja, satisfará o jus puniendi, que é o objeto da prescrição no processo administrativo disciplinar.

Note-se que a estrita legalidade rege a Administração Pública e que eventuais excessos verificados, são desvios de poder que deverão ser punidos. Na falta de regramento legal específico, prevalece a legislação subsidiária e não o arbítrio.

\subsection{Espécies.}

A doutrina trata do processo administrativo disciplinar em sentido amplo que constitui gênero do qual são espécies a sindicância e o processo administrativo disciplinar propriamente dito, ou em sentido estrito.

A legislação também fez tal distinção, a Lei $n^{\circ}$ 8.112/90 (que estatui o regime jurídico dos servidores públicos da União, autarquias e 
fundações públicas federais) denomina o Título $\mathrm{V}$ como "Processo Administrativo Disciplinar", tratando em seguida da sindicância e do processo disciplinar.

\subsubsection{Sindicância.}

Há doutrinadores que comparam e estabelecem analogia dizendo que a sindicância é para o processo administrativo disciplinar mutatis mutandis o que o inquérito é para a ação penal, sendo, justamente por isso, dispensável, tal qual ocorre no processo penal. Em que pese à veracidade da última assertiva, não pode prevalecer o entendimento que consagra os institutos enquanto paralelos nos dois ramos do Direito.

É que no sistema adotado pela Lei $n^{\circ} 8.112 / 90$ (bem como em boa parte das legislações estaduais e municipais), a sindicância não se resume a mero procedimento informativo de instrução.

Da sindicância podem advir sanções, como advertências e suspensões, por exemplo. Isto, por si a qualifica enquanto modalidade de processo administrativo disciplinar.

Em verdade, a sindicância poderá ser instrumento preliminar para apuração de faltas, porém isto não retira seu caráter de processo, mesmo porque não só a amplitude de defesa, como também o contraditório nela estarão presentes.

A sindicância é, atualmente, o meio sumário de processo administrativo, devendo seguir os ditames constitucionais já referidos. Diz-se isto com o fito de rechaçar toda e qualquer sugestão que pretenda aproximar a sindicância, enquanto meio sumário de apuração do ilícito, do sepultado instituto da verdade sabida.

Entretanto, algumas considerações se fazem necessárias a respeito da verdade sabida, que é tanto o conhecimento pessoal da infração pela própria autoridade competente para punir o infrator quanto à infração pública e notória, estampada na imprensa ou divulgada por outros meios de comunicação de massa $^{65}$. Por tal meio poderia o superior hierárquico imediatamente aplicar a punição ao infrator. Importante se notar que a inaplicabilidade da verdade sabida não se contrapõe ao uso corretivo do poder hierárquico, do estrito cumprimento do dever legal ou mesmo da

\footnotetext{
${ }^{65}$ MEIRELLES, Hely Lopes. Direito Administrativo Brasileiro. 32a ed., São Paulo, Malheiros, 2006.
} 
legítima defesa; entretanto em havendo impugnação ao ato, deverá haver o contraditório e a ampla defesa ${ }^{66}$, onde poderá ser demonstrada a licitude do ato.

Por derradeiro, a sindicância poderá ser utilizada enquanto mecanismo meramente investigativo, quando deixará de ser acusatória, passando a averiguatória, que precederá e instruirá o processo administrativo disciplinar posterior.

\subsubsection{Processo administrativo disciplinar (sentido}

estrito).

Em sentido estrito o processo administrativo disciplinar, também é chamado de inquérito administrativo e é o meio de apuração $e$ punição de faltas graves dos servidores públicos e demais pessoas sujeitas ao regime funcional de determinados estabelecimentos da administração ${ }^{67}$. É processo sancionador, com fulcro no poder disciplinar, oriundo do vínculo jurídico entre a Administração e o infrator.

Conforme explicitado quando tratado da responsabilidade, o processo administrativo não exclui a apuração criminal, ainda que o ilícito simultaneamente seja classificado enquanto fato típico penal.

De outro lado, também não é necessário que a previsão administrativa seja idêntica, ou mesmo muito semelhante à criminal para que haja a apuração e punição do ilícito. É que no direito administrativo a "tipificação" é - em regra - mais aberta e genérica, sem que isto represente qualquer irregularidade. Note-se, por exemplo, a existência de procedimento irregular ou falta de exação e ainda a insubordinação, todos os procedimentos irregulares e passíveis de punição, em que pese à abrangência do vocábulo descritivo.

Desta forma fica cristalina a existência de discricionariedade, típica da Administração Pública, nos processos administrativos; note-se que isto não se contradiz com o devido processo legal, nem mesmo com o dever de apuração, apenas possibilita um enquadramento de mais amplo de condutas, gerando maior ângulo de atuação na apuração das faltas.

\footnotetext{
${ }^{66}$ Sabidamente incluídos entre no rol de direitos e garantias individuais da Constituição Federal, e tal rol é cláusula pétrea no ordenamento.

${ }^{67}$ OCTAVIANO, Ernomar; GONSALEZ, Átila J.: Sindicância e processo administrativo, 10ª ed, Brasília, Universitária de Direito, 2002.
} 
Conforme já mencionado, o ilícito administrativo penal e o puro serão apurados por processo administrativo (eventualmente podendo o ser por sindicância), bastando para tanto que haja relação jurídica funcional ou hierárquica entre o suposto infrator e a Administração.

A apuração por meio de processo administrativo deve ser vista não apenas como um dever da Administração, mas também como garantia dos administrados, pois evita desmandos daquela sobre estes.

Tendo em vista a competência legislativa para a regulamentação dos processos administrativos, temerária qualquer menção às autoridades que podem dar ensejo a sua instauração, pois cada ente federativo poderá em cada procedimento, prever de maneira específica.

\subsection{Princípios constitucionais.}

Os princípios, no mais das vezes estão relacionados entre si, mormente quando decorrentes de um princípio constitucional fundamental (no dizer de Luís Roberto Barroso) ou estruturante como diz J. J. Gomes Canutilho.

E o princípio constitucional fundamental em nosso ordenamento que traduz as diretrizes básicas de todo o Direito pátrio é o Estado de Direito, inserido no artigo $1^{\circ}$ caput da Constituição Federal, justamente no Título I cuja dicção é "Dos Princípios Fundamentais".

Do princípio do Estado de Direito decorrem subprincípios, também com caráter normativo. J. J. Gomes Canotilho vislumbra os seguintes sub-princípios: legalidade da Administração; segurança jurídica; proibição do excesso; proteção jurídica e das garantias processuais ${ }^{68}$.

Os princípios constitucionais aplicáveis ao processo administrativo disciplinar são justamente os que decorrem do próprio Estado de Direito, a legalidade, a segurança jurídica, a proporcionalidade e o devido processo legal. Todos com subdivisões e entrelaçados, uma vez que decorrentes de mesma origem.

Diante disto recorre-se ao pensamento de Genaro Carrióo $^{69}$, para quem as classificações jurídicas não devem ser vistas enquanto certas ou

${ }^{68}$ CANOTILHO, José Joaquim Gomes: Direito constitucional, $3^{\mathrm{a}}$ ed, Coimbra, Almedina, 1999.

${ }^{69}$ CARRIÓ, Genaro R.: Notas sobre Derecho y Lenguage, Buenos Aires, Abeledo-Perrot, 1976. 
erradas, mas como úteis ou inúteis. A útil é aquela que torna uma questão ou assunto mais compreensível, ou enriquece seu estudo.

Assim, segundo tal orientação, não parece útil, ao contrário, compartimentar os princípios em classificação estanque, uma vez que a relação entre eles é inegável e seu entrelaçamento fundamental ao processo administrativo disciplinar.

A partir do quarteto de princípios já elencados podem ser verificados todos e quaisquer sub-princípios aplicáveis ao direito administrativo sancionador.

\subsection{Fases.}

\section{Quatro são as fases do processo administrativo}

disciplinar, a primeira dela é a fase de instauração que se deflagra com a edição de portaria da autoridade competente e deverá designar comissão processante; os membros desta deverão ter conduta ilibada e tecnicamente capazes para apurar as faltas levantadas.

Caso já existam comissões permanentes no órgão responsável pela apuração, por óbvio desnecessária a formação de comissão pela portaria, apenas será indicada tal realidade, a contrario sensu, a não indicação de comissão é defeito grave que invalida a portaria.

Sempre que na comissão não houver membro com formação jurídica deverá, ex officio ou a requerimento da comissão, ser nomeado profissional da área de direito para auxiliar nos trabalhos, dando suporte ao regular andamento do processo, garantindo os direitos dos servidores e a validade do processo administrativo disciplinar. A nomeação do auxiliar também se dará por portaria.

São ainda requisitos da portaria inicial: o órgão onde o processo tramitará; a autoridade responsável; fundamentação legal da competência e legitimação da autoridade; os fatos que serão apurados; individualização do acusado; membros da comissão processante e os poderes atribuídos a esta. É desejável que aspectos formais como locais de reunião sejam definidos antes da formação dos autos.

Autuado o processo, será dada ciência ao acusado, passando-se à fase de instrução (de inquérito administrativo, para alguns), cuja tripartição é feita para fins didáticos. 
De início repise-se ser a instrução o cerne do processo, pois dela dependerão a elucidação dos fatos, com a produção de provas (que é a primeira parte da instrução). Estas poderão ser de toda e qualquer espécie (documentais, periciais, testemunhais, inspeções pessoais e depoimento pessoal, etc.) desde que lícitas.

A produção de provas pela Administração deve sempre ser seguida de oportunidade de argumentação da defesa (segunda parte da instrução), em face do contraditório e na maior amplitude dada a esta.

A defesa terá acesso irrestrito às provas produzidas podendo atacar todo e qualquer aspecto no processo, no entanto deve pautar-se pela lealdade processual, sendo responsável por atos meramente protelatórios por exemplo.

Realizados todos os atos de defesa, é encerrada a segunda parte da instrução, passando-se ao seu derradeiro momento, o relatório que é um resumo daquilo que foi efetivamente apurado por meio do processo. Deverá conter análise minudente dos autos e uma proposta conclusiva e fundamentada para decisão da autoridade julgadora competente. Tal proposta, entretanto não é vinculante.

A terceira fase julgamento no processo administrativo, clímax deste e fundamentada nas fases anteriores - nela será definida a sanção a ser aplicada, tornando o jus puniendi concreto.

Mais uma vez interessante a subdivisão de tal fase, com finalidade didática. A decisão administrativa compõe-se de três partes: relatório, fundamentação e dispositivo.

O relatório trará síntese do feito administrativo, num breve histórico, localizando, especificamente, as acusações contidas nos autos e os elementos apresentados pela defesa, sua função é indicar quais foram e qual a forma das provas que foram produzidas, nesta parte não há espaço para juízo de valor; este é típico da fundamentação que nada mais é que a análise das provas produzidas perante a legislação pertinente. Tal argumentação deverá ser precisa, no entanto não necessariamente extensa, bastando que a partir das provas seja obtida conclusão plausível e fundamentada. Por último, teremos a parte dispositiva da decisão, na qual serão as imputações julgadas procedentes ou não, aplicando as medidas que forem cabíveis.

Por derradeiro subsiste a fase recursal, cuja existência á obrigatória, no entanto seu exercício não. Melhor delineando, há impedimento para a supressão de qualquer das fases do processo administrativo, no entanto o conformismo de todos os interessados com a decisão, traduzido pela ausência de recurso, 
não significa inexistência de fase recursal naquele processo. $\mathrm{O}$ não exercício do direito recursal não o suprime. Assim, de se afirmar peremptoriamente que a fase recursal é obrigatória, entendendo-se tal obrigatoriedade enquanto previsão legal e não como existência de recurso ex officio, por exemplo. O que não pode ser deixado de lado é a possibilidade dada ao administrado, de ter ao caso concreto a aplicação do princípio do duplo grau nas decisões. Em suma o recurso é faculdade do interessado, mas a previsão de fase recursal é obrigatória.

\subsection{Penalidades.}

Com relação às penalidades, adota-se a classificação de Edmir Netto de Araújo, em seu Curso de Direito Administrativo, que é a seguinte:

As penalidades poderão ser classificadas em quanto ao gênero e quanto à espécie.

Com relação ao gênero surgem duas subdivisões,

natureza e finalidade:

“... quanto à natureza: morais, pecuniárias, mistas e profissionais.

As sanções morais atingem o funcionário em seu amor-próprio, brio, reputação. As penas pecuniárias, como a multa, incidem sobre o patrimônio, as finanças do infrator. As mistas atingem a ambos, como a suspensão: foro íntimo e patrimônio. Por fim, a penalidade profissional, castiga o funcionário em função de sua carreira ou situação funcional, não sendo necessariamente catalogada expressamente entre as penas disciplinares dos Estatutos. A transferência, a remoção, a colocação em disponibilidade e (Administração federal) a destituição de função, são exemplos desse tipo de penalidade; esta última com reflexos também morais e patrimoniais;

quanto à finalidade: corretivas, explosivas e revocatórias:

Corretivas são penas que visam a emenda e a recuperação do servidor infrator, que continua no serviço público após a sanção aplicada. Repreensão, suspensão e multa são penalidades corretivas. Expulsivas: protegem o cargo ou função, e o serviço público em geral, objetivando o desligamento do servidor dos quadros da Administração, conforme o grau de incompatibilidade com o serviço público 
gerada pela natureza gravíssima da falta praticada. A demissão, que na CLT é sinônimo de "despedida", é o exemplo tradicional.

Com as penalidades revocatórias (o próprio nome o diz), a Administração revoga, na salvaguarda do interesse público, uma situação já estabelecida para o servidor (ou inativo). Assim, cassa-se a aposentadoria ou a disponibilidade, ou destitui-se (revoga-se a designação) de função gratificada, geralmente exercida a título precário ou em comissão".

Traz, ainda, o autor em referência as seguintes penalidades administrativas em espécie: repreensão ou advertência escrita; suspensão; multa; destituição de função comissionada ou de cargo em comissão; cassação de aposentadoria ou disponibilidade; demissão; demissão a bem do serviço público.

Urge salientar - uma vez mais - que dada a competência comum dos entes federados para legislar a respeito do processo administrativo, não há padronização exata das penalidades, razão pela qual há possibilidade de algumas delas existirem em um ente federado e em outro não. Em âmbito federal, por exemplo, é prevista a destituição de função comissionada e não está entre as penalidades a demissão a bem do serviço público, inversamente ao que ocorre no Estado de São Paulo que silencia com relação à primeira e traz a segunda em seu rol de penalidades.

Sintetizando em um quadro, temos as seguintes penalidades administrativas: 


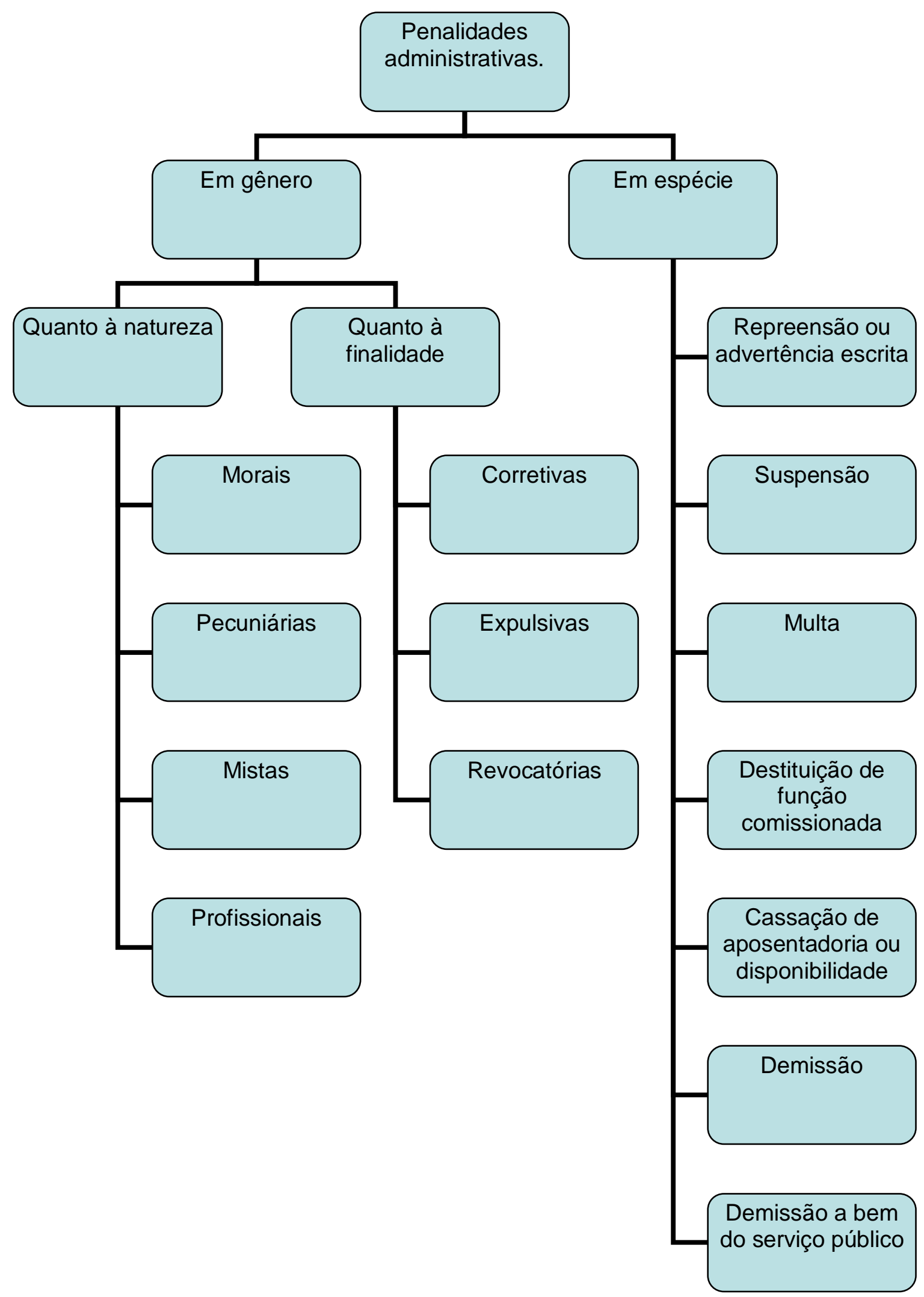




\section{A prescrição no processo administrativo disciplinar.}

\subsection{Nota inicial.}

Que, como sustentado anteriormente, a prescrição é uma realidade indissociável do ordenamento jurídico moderno e que é regra, sendo a imprescritibilidade exceção não resta dúvida, diante de todo o dito quando abordado o tema prescrição, em sentido amplo. Porém, em sede de processo administrativo disciplinar a própria legislação pátria é reticente na adoção de critérios objetivos e claros, demonstrando o pleno cabimento da prescrição.

A falta de técnica legislativa apta a não criar descompassos e verdadeiras contradições no ordenamento se deve, principalmente, a uma visão deturpada do que representa o acolhimento de prescrição.

Por vezes - mormente em uma sociedade na qual é voz corrente a impunidade e o arbítrio da Administração Pública - os legisladores sentem-se constrangidos em aprovar uma norma tecnicamente mais adequada, mas que poderá soar aos olhos dos eleitores enquanto "corporativa", visando objetivos espúrios. E, opta a maioria da casa legislativa por texto que embora tecnicamente inferior e gerador de controvérsias (até eivado de mácula de inconstitucionalidade) perante o eleitorado terá impacto positivo.

A questão da contagem dos prazos prescricionais na lei que regulamenta o regime jurídico dos servidores civis da União ${ }^{70}$ é exemplo típico da prática legislativa ora criticada.

A partir deste breve intróito, tratar-se-á da prescrição aplicada diretamente ao processo administrativo disciplinar.

\subsection{A legislação federal.}

A Lei Federal 8.112 de 11 de dezembro de 1990, que trata sobre o regime jurídico dos servidores públicos civis da União, das autarquias e das fundações públicas federais, ao tratar da prescrição estabelece:

\footnotetext{
${ }^{70}$ Transcrito por diversos entes da federação, salvo honrosas exceções como o Estado de São Paulo, por exemplo.
} 
Art. 142. A ação disciplinar prescreverá:

I - em 5 (cinco) anos, quanto às infrações puníveis com demissão, cassação de aposentadoria ou disponibilidade e destituição de cargo em comissão;

II - em 2 (dois) anos, quanto à suspensão;

III - em 180 (cento e oitenta) dias, quanto á advertência.

$\S 1^{\underline{0}}$ O prazo de prescrição começa a correr da data em que o fato se tornou conhecido.

$\S 2^{-}$Os prazos de prescrição previstos na lei penal aplicam-se às infrações disciplinares capituladas também como crime.

$\S 3^{\circ}$ A abertura de sindicância ou a instauração de processo disciplinar interrompe a prescrição, até a decisão final proferida por autoridade competente.

$\S 4^{0}$ Interrompido o curso da prescrição, o prazo começará a correr a partir do dia em que cessar a interrupção.

Com relação aos prazos estabelecidos, tendo em vista a discricionariedade para sua demarcação, não serão tecidas críticas, mas a dicção dos parágrafos merece análise mais detida, para a qual será necessário retomar alguns assuntos tratados nas duas primeiras partes deste estudo.

\subsection{Prescrição disciplinar é algo nefasto?}

A importância da prescrição para o ordenamento jurídico já foi abordada tanto na introdução quanto na segunda parte do trabalho, mas face ao assunto que será abordado, mais alguns comentários se fazem necessários.

A prescrição é fundamentada, como sustentado desde a primeira parte deste estudo, no princípio da segurança jurídica, que decorre diretamente do princípio do Estado Democrático ${ }^{71}$ e visa à paz social. O Estado possui, conforme sabido, o objetivo maior de alcançar o bem comum no sentido mais amplo que tal expressão pode receber.

A prescrição é, portanto, um instrumento para obtenção de segurança jurídica que irá gerar paz social, necessária para a convivência em uma sociedade justa e democrática, objetivo maior do Estado. Sendo assim, não pode ser a

\footnotetext{
${ }^{71}$ O Estado Democrático é Estado de Direito, porém nem sempre o Estado de Direito é democrático.
} 
prescritibilidade vista como instrumento de impunidade. Se ao Estado é dado o poderdever de apurar a responsabilidade e punir àqueles que descumprem as normas estabelecidas, tal poder não pode permanecer permanentemente, afinal, no frigir dos acontecimentos a possibilidade de punição leva a insegurança jurídica, incompatível com uma sociedade livre, justa e solidária.

Como argumento final, invoque-se a conhecida frase de Franz Kafka diante de uma sociedade totalitária o Tribunal não esquece nada!

Imaginar que a prescrição milita para a impunidade é visão simplória do alcance do instituto. Ignorando que a imprescritibilidade agravará a injustiça ao invés de atenuá-la.

\subsection{Parágrafo $1^{\circ}$ do artigo 142 da Lei $n^{0} 8.112 / 90$.}

Em que pese toda a argumentação até agora desenvolvida, o legislador traz como dies a quo da prescrição em âmbito disciplinar a data em que o fato se tornou conhecido pela autoridade.

Tal previsão faz com que, em termos práticos haja verdadeira imprescritibilidade da possibilidade de punição, como será visto.

A instabilidade do dies a quo do prazo prescricional não pode ser admitida pelo direito, tendo em vista - repise-se - que a regra geral é a da prescrição e não a da sua interrupção ou suspensão indefinidamente.

O jus puniendi do Estado decorre da prática do ato ilícito do agente público, sendo o exercício do poder punitivo, limitado pelo próprio Estado Democrático.

Verificada, a prática do ato ilícito pelo servidor público, o termo inicial da prescrição disciplinar é o do dia em que o mesmo foi praticado, sendo totalmente incongruente considerar-se o dia de sua ciência pela Administração; mesmo porque os atos produzem efeitos jurídicos a partir da ocasião em que foram praticados.

Nem se argumente que isto beneficia o infrator cuidadoso que bem camufla as suas atividades ilícitas. Pois ainda assim, será inadequado ao Estado permanecer indefinidamente com o poder de punição do servidor. O Estado deverá criar e manter mecanismos de controle que permitam o conhecimento ágil de 
eventuais ilícitos, mas não pode ser beneficiado - no fim das contas - face à sua falta de controle.

Tal situação a se perpetuar, criaria um Estado sem preocupação de eficiência e controle, afinal a qualquer tempo poderia vir a punir as condutas, mais que isto, o Estado poderia passar a não buscar conhecer os ilícitos para que os prazos não fossem iniciados.

Ou seja, é totalmente absurdo, ilógico e contrário ao direito afirmar-se que aquele que praticar ilícito administrativo, tenha que aguardar a Administração alegar que tomou conhecimento do fato oficialmente.

Ao utilizar raciocínio inverso, verifica-se que o Estado, quando lesa ou viola direitos de pessoas ou terceiros, concede ao lesado a oportunidade de tentar reformar ou anular seus atos até 5 (cinco) anos do dia em que foi praticado o ato e não do conhecimento do mesmo pelo lesado.

Porque inverter este princípio quando se trata de ato ilícito administrativo do servidor público, ao ponto de considerar o dies a quo o da data do conhecimento da Administração Pública?

Não existe justificativa para tal ilegalidade, visto que o dia em que começa a fluir o prazo prescricional (dies a quo) deve ser, sempre, aquele em que se pratica o ato ilícito.

No caso da infração disciplinar, a situação é bem curiosa, pois ela se subdivide em ilícito penal e ilícito administrativo puro.

No ilícito administrativo penal, o $\S 2^{\circ}$, do art. 142 , da Lei no 8.112/90, a prescrição é contada "a partir do fato", independentemente da autoridade administrativa ter tido ciência do evento, eis que remete os prazos de prescrição previstos para a lei penal. Assim, quando a infração investigada for: peculato, concussão, corrupção passiva, prevaricação, facilitação de contrabando, advocacia administrativa, violação de sigilo funcional, abandono de cargo ou função, a prescrição começa a fluir da consumação do fato ilícito praticado e investigado.

Sucede que o mesmo direito administrativo disciplinar estabelece, na infração que não seja capitulada como crime, outro critério para o termo inicial da prescrição, qual seja, é contado da ciência da Administração e não da prática fato tido como irregular ( $\S 1^{\circ}$, do art. 142, da Lei $\left.n^{\circ} 8.112 / 90\right)$.

Ora, o problema relativo à prescrição não pode sofrer uma regra diversa da prevista no Código Penal, pois tanto no momento da consumação do 
crime, quanto no dia da prática da infração disciplinar, o termo inicial da prescrição é o da data em que o crime se consumou, conforme previsto no art. 111, I ao VI, do CP, onde existe a previsão de exceções à regra geral do inc. I.

Isto porque, o que se torna relevante para o direito é o momento em que o agente público praticou o ato contrário ao comando da lei.

Por esta razão, o art. 79, do Código Penal Brasileiro de 1890, já estabeleceu: "Art. 79 - A prescrição da ação resulta exclusivamente do lapso do tempo decorrido do dia em que o crime foi cometido."

Assim, desde aquela fase do direito penal, se estabeleceu como regra geral que o prazo prescricional flui da data em que o crime se consumou e não quando o fato se tornou público/conhecido, para que não ocorra o indevido alargamento extremado da prescrição, criando incerteza nas relações jurídicas, contrário ao estabelecido na atual redação do art. 111, I, do Código Penal (termo inicial da prescrição antes de transitar em julgado a sentença final), havendo exceções.

Não é admissível que a Administração Pública se beneficie da sua inércia para trazer a instabilidade jurídica para os seus subordinados.

Contra a instabilidade jurídica gerada pela imprescritibilidade manifestou-se o Min. Moreira Alves ${ }^{72}$, por meio de seu voto vencedor no $\mathrm{MS} \mathrm{n}^{\circ} 20.069$, onde asseverou que:

"se até as faltas mais graves - e, por isso mesmo, também definidas como crimes - são, de modo genérico, suscetíveis de prescrição, no plano administrativo, não há como pretender-se que a imprescritibilidade continue a ser o princípio geral, por corresponder ao escopo da sanção administrativa, ou seja, o interesse superior da boa ordem do serviço público (...) Em matéria de demissão, não há qualquer razão, por causa da gravidade, para se considerar que possa prescrever a pretensão punitiva da Administração Pública, quanto a crimes e à ausência ao serviço, 60 dias interpoladamente sem causa justificada, e não possa prescrever a mesma pretensão, quanto à faltas menos graves do que as definidas como crime e que, como ausência contumaz, são de natureza meramente funcional. Haverá quem sustente que é o interesse superior da boa ordem do serviço público que permite a prescritibilidade, quanto à

${ }^{72}$ STF, Rel. p/ acórdão Min. Moreira Alves, MS nº 20069, julgado em 24.11.76, RDA 135:75. 
faltas que configuram crime, e a imprescritibilidade, no tocante a algumas poucas de natureza meramente funcional?"

A seguir, o Min. Moreira Alves arremata ${ }^{73}$ : "... noutras palavras, se os crimes ditos contra a Administração, tipificados no Código Penal estão sob o amparo da prescrição penal, por que motivo não introduziu esse instituto também no âmbito administrativo? Fosse por deliberado propósito, fosse por mera omissão, o vigente Estatuto recusou guarida à prescrição da falta disciplinar. Postou-se, assim, como a célebre espada do episódio de Dâmocles sobre a cabeça do servidor público, acessando-lhe com a ameaça de punição em qualquer época até a mais remota, depois de cometido e olvidado o fato."

A bem da verdade, melhor seria uma regulamentação uniforme para todos os ilícitos administrativos, em que pese a já mencionada competência legislativa comum.

Vigora em nosso direito positivo, como já dito alhures, a regra da prescritibilidade, ferindo a razoabilidade dividir o termo inicial da prescrição da grave pena de demissão, ou seja, quando for oriunda de uma infração tipificada como crime, o dies a quo é o da data em que este se consumou, ao passo que se a irregularidade funcional for derivada de disposições estatutárias, o termo inicial é o da data do conhecimento da Administração Pública.

A redação do $\S 1^{\circ}$, do art. 142, da Lei no 8.112/90 é insustentável, pois ela privilegia a tese da imprescritibilidade da sanção administrativa, como averbado por José Cretella Júnior ${ }^{74}$ :

"... é insustentável a tese da imprescritibilidade da sanção administrativa, defendida por ilustres cultores do Direito Administrativo, porque o fundamento da prescrição tem de ser buscado na categoria jurídica, sendo o mesmo para o Direito Penal e para o Direito Disciplinar, havendo diferenças, é claro, apenas naquilo que o Direito Positivo de cada país preceituou para uma e outra figura. A prescrição penal e a prescrição administrativa são espécies, repetimos, entre outras, da figura categorial 'prescrição', que reponta em vários ramos do Direito, definindo-se genericamente, como 'a perda do direito de punir, em decorrência do

${ }^{73}$ STF, Rel. p/ acórdão Min. Moreira Alves, MS nº 20069, julgado em 24.11.76, RDA 135:75.

${ }^{74}$ CRETELLA JÚNIOR, José. Prescrição Administrativa. in Revista dos Tribunais 544/12, RT. 
tempo.' 'Os Estatutos do funcionalismo brasileiro dispõem que a punibilidade da falta administrativa também prevista em lei como crime, prescreve no mesmo prazo correspondente à prescrição da punibilidade deste. No caso, deixam de vigorar as regras estatutárias, estabelecidas pelo Direito Disciplinar e aplicadas quando tudo ainda se passa na esfera administrativa, para prevalecer a orientação do Direito Penal, fixada no capítulo 'Da extinção da punibilidade', catalogada na Parte Geral do nosso Código Penal."

Outrossim, no tocante à fixação do dies a quo de incidência da prescrição, José Cretella Júnior ${ }^{75}$ defende também a interpretação extensiva das disposições estatutárias, a fim de que o servidor público se beneficie das regras penais da prescrição "a partir do fato" e jamais "a partir da ciência do fato", verbis:

"No estudo da prescrição da falta disciplinar, o aspecto mais relevante é a fixação do dies a quo, do momento 'a partir do qual' principia a fluir o prazo para a extinção da iniciativa de punir. O prazo, na esfera administrativa, pode escoar-se em decorrência: a) da inércia da Administração que, conhecendo o fato, deixa, por qualquer motivo, de abrir o devido processo administrativo para apurá-lo; $b$ ) da ignorância ou insciência do fato; $c$ ) do processo administrativo aberto, mas indefinidamente prolongado, até a prescrição, pelo decurso do tempo, fixado no Estatuto.' 'A terceira hipótese é equiparada também ao que decorre na esfera do Direito Penal quando, cometida a infração, a prescrição atinge o poder punitivo do Estado, antes da condenação, no decorrer do processo, cumprindo à Administração distinguir se trata de ilícito administrativo puro ou ilícito administrativo crime.' 'Em suma, a extrema gravidade da pena de demissão, não há a menor dúvida de que se deve dar às disposições estatutárias pertinentes interpretação extensiva, a fim de que o agente beneficie-se com as regras penais da prescrição 'a partir do fato' e jamais 'a partir da ciência do fato'. Do contrário, chegaríamos ao absurdo, repetimos, de ser beneficiado com a regra da prescrição penal o agente público que cometeu crime contra a Administração ao qual o Estatuto comina a pena de demissão e de ser prejudicado com a regra da prescrição estatutária o funcionário que cometeu puro ilícito administrativo, ao qual, também, a pena cominada é a demissão."

${ }^{75}$ CRETELLA JÚNIOR, José. Prescrição Administrativa. in Revista dos Tribunais 544/12, Ed. RT. 
Incorporando essas razões, o Min. Fernando Gonçalves, conferiu interpretação extensiva das disposições estatutárias às regras penais da prescrição e estabeleceu o dies a quo a partir da ocorrência do fato: "... na espécie, o art. 117, IX, da Lei no 8.112/91, deve a prescrição regular-se pelo art. 142 daquele Diploma Legal, que prevê o prazo de cinco anos, contados a partir da ocorrência do fato, em face da extrema gravidade da pena de demissão. ${ }^{76 "}$

Brasilino Pereira dos Santos $^{77}$, afirma que o art. 142, $\S 1^{\circ}$, da Lei $\mathrm{n}^{\mathrm{o}} 8.112$, de 11 de dezembro de 1990, “deve ser tido como não escrito, não só nos casos de infração criminal pura, como também nos casos de infração disciplinar e criminal".

Segundo o referido autor, mais coerente com os princípios doutrinários é a Lei Complementar $n^{\circ} 75$, de 20 de maio de 1993, que dispõe sobre a organização, as atribuições e o estatuto do Ministério Público da União, que, no particular, dispõe:

\section{Art. 244. Prescreverá:}

I - em um ano, a falta punível com advertência ou censura;

II - em dois anos, a falta punível com suspensão;

III - em quatro anos, a falta punível com demissão e cassação de aposentadoria ou de disponibilidade.

Parágrafo único. A falta, prevista na lei penal como crime, prescreverá juntamente com este.

Art. 245. A prescrição começa a correr:

I - do dia em que a falta for cometida; ou

II - do dia em que tenha cessado a continuação ou permanência, nas faltas continuadas ou permanentes.

Parágrafo único. Interrompem a prescrição a instauração de processo administrativo e a citação para a ação de perda do cargo.

Para Edmir Netto de Araújo ${ }^{78}$, a presente situação narrada se afigura como aberração dos dispositivos estatutários federais:

\footnotetext{
${ }^{76}$ STJ, Rel. Min. Fernando Gonçalves, MS 6877/DF, $3^{\text {a }}$ S., DJ de 21.05.2001, p. 55.

${ }^{77}$ SANTOS, Brasilino Pereira dos. O prazo da prescrição de punição disciplinar começa a correr do momento em que o fato se tornou conhecido? . Jus Navigandi, Teresina, ano 5, n. 51, out. 2001. Disponível em: <http://jus2.uol.com.br/doutrina/texto.asp?id=2278>. Acesso em: 12 mai. 2008.

${ }^{78}$ ARAÚJO, Edmir Netto de. O ilícito Administrativo e o seu Processo, São Paulo: ed. RT, 1994, p. 249.
} 
"... certas aberrações decorrentes dos dispositivos estatutários, especialmente federais, como se acham em vigor, mesmo cumprida a determinação constitucional (art. 37, $\S 5^{\circ}$ ) para fixação, por lei, dos prazos de prescrição de ilícitos administrativos. 1) a primeira delas: a prescrição da ação disciplinar do ilícito administrativo que ocasiona demissão, mesmo agravada, tem seu termo inicial da data do conhecimento da infração, ao passo que a falta-crime a tem na data do fato. Ou seja, é provável que, muitas vezes, a infração mais grave deixa de ser punível antes da infração menos grave. 2) A fixação do dies a quo na data do conhecimento da autoridade, e interrupção da prescrição pela instauração do respectivo procedimento administrativo levam a outros absurdos: será quase impossível ao servidor, especialmente federal, na prática livrar-se de punição."

O direito não pode servir como eternização de uma futura punição disciplinar, capaz de ser manejada quando a Administração Pública se dignar a afirmar que tomou conhecimento de um fato após o transcurso do tempo. O jus puniendi não é absoluto e perpétuo, ele se sujeita à regra da segurança jurídica e do princípio da razoabilidade, dentre outros, exatamente para possibilitar a paz coletiva, afastando a idéia de um processo perpétuo.

O prazo de cinco anos, contados a partir do ato tido como irregular não é suficiente para promover a apuração disciplinar, e se for o caso, após o due process of law, estabelecer a penalidade?

Entendendo que este critério é mais do que suficiente para apurar a impunidade.

Neste sentido, veja-se a afirmação de Mauro Roberto Gomes de Mattos "O prazo de prescrição é contado da data do ato tido como violador de deveres funcionais, pois não se admite, em hipótese alguma, que a Administração Pública não conheça seus atos, que são púbicos a todos, sendo-lhe defeso alegar torpeza ou desconhecimento." 79

Portanto, a interrupção do início da contagem do prazo de prescrição até que a Administração Pública declare que tomou conhecimento do

${ }^{79}$ MATTOS, Mauro Roberto Gomes de. Lei $n^{o}$ 8.112/90 Interpretada e Comentada. Rio de Janeiro: ed. América Jurídica, 2005, p. 721. 
fato tido como ilícito administrativo não se coaduna com o instituto da prescritibilidade que permeia o Estado Democrático.

Da forma como está redigido o $\S 1^{\circ}$, do art. 142 , da Lei $n^{\circ}$ 8.112/90, ele não foi recepcionado pela redação do art. 5, LXXVIII, da Constituição Federal, que garante a todos, no âmbito judicial ou administrativo, duração razoável do processo, com a utilização de meios que garantam a celeridade de sua tramitação.

Ora, não é mais admissível que possa haver na legislação infraconstitucional preceito capaz de impedir o curso da prescrição no processo administrativo disciplinar de forma permanente, até que a Administração Pública declare a sua ciência ou conhecimento de um ato praticado em seu nome.

Essa filosofia mais se coaduna com o brocardo the king can do no wrong que com o Estado Democrático.

Neste, os indivíduos passam a ter constitucionalmente assegurado não só a prestação da tutela jurisdicional tempestiva, como também a celeridade na tramitação de processo administrativo.

Sendo entendida como celeridade a fruição de um tempo razoável no transcurso de procedimentos judiciais e administrativos, contrapondo-se a sua interrupção ou suspensão ad aeternum do prazo de prescrição no procedimento disciplinar, visto que o Poder Público também é destinatário do comando constitucional a que alude o inciso LXXVIII, do art. 5. Mas a duração razoável do processo ficará para outro tópico.

Apesar de toda a argumentação acima exposta, fundada na melhor doutrina, não é o entendimento da União, representada pelo Presidente da República. É que, tal autoridade aprovou em 30 de janeiro de 1995 o parecer GQ 55/1995, oriundo da Advocacia Geral da União, que é vinculante por força da Lei Complementar $n^{\circ} 73 / 93$ :

A inércia da Administração somente é suscetível de se configurar em tendo conhecimento da falta disciplinar a autoridade administrativa competente para instaurar o processo. Considerar-se a data da prática da infração como de início do curso do lapso temporal, independentemente do seu conhecimento pela Administração, sob a alegação de que a aplicação dos recursos públicos são objeto de auditagens permanentes, beneficiaria o servidor faltoso, que se cerca de cuidados para manter 
recôndita sua atuação anti-social, viabilizando a mantença do proveito ilícito e a impunidade, bem assim não guardaria conformidade com a assertiva de que a prescrição viria inibir o Estado no exercício do poderdever de restabelecer a ordem social, porque omisso no apuratório e apenação.

Em resumo, não bastasse a legislação falha, o Poder Executivo contribui para tornar a matéria - cuja inconsistência perante o ordenamento jurídico é flagrante - polêmica.

O parecer acima transcrito não tratava da Lei $n^{\circ}$ 8.112, que é a ele posterior, no entanto seu entendimento prevaleceu no Superior Tribunal de Justiça após a vigência de tal norma, neste sentido:

STJ MS 6547 (DJ: 23/04/2001) Relator: Felix Fischer

Voto: [...] Ocorre que, conforme dispõe o $§ 1^{\circ}$ do art. 142 acima indicado, o prazo começa a correr da data em que o fato se tornou conhecido. Em vista dessa disposição expressa, não se pode considerar como dies a quo do lapso prescricional o dia em que foi concedido o benefício, porque nessa ocasião não foi constatada ainda a infração. In casu, deve-se considerar como o momento em que se tomou conhecimento da infração a data em que a autoridade competente para instaurar o processo soube da falta disciplinar, [...] (grifo nosso)

STJ MS 8251 (DJ: 14/04/2003) Relator: Jorge

Scartezzini

Ementa: [...] 1 - Não há que se falar em ocorrência da prescrição da pretensão punitiva disciplinar, tendo em vista que o prazo prescricional começou a fluir do momento em que a Administração tomou conhecimento da infração; no caso, da data em que a autoridade competente para instaurar o processo soube da falta disciplinar. $[\ldots]$ (grifo nosso)

STJ MS 8595 (DJ: 07/04/2003) Relator: Felix Fischer

Voto: [...] Ocorre que, conforme dispõe o $\S 1^{\circ}$ do art. 142 acima indicado, o prazo começa a correr da data em que o fato se tornou conhecido. Em vista dessa disposição expressa, não se pode considerar como dies a quo do lapso prescricional o dia em que foi concedido o benefício ou praticados os atos que ensejaram a sua cassação, porque nessa 
ocasião não foi constatada ainda a infração. In casu, deve-se considerar como o momento em que se tomou conhecimento da infração a data em que a autoridade competente para instaurar o processo soube da falta disciplinar, em 10/04/2001 (fls. 43 e 51/52). Nesse sentido é a lição de FRANCISCO XAVIER DA SILVA GUIMARÃES (Regime Disciplinar do Servidor Público Civil da União, Forense, 1998, p. 165): "Com efeito, se a prescrição extingue o direito de punir administrativamente, em razão de decurso de prazo legal, por inércia ou negligência, só se caracterizará a partir do conhecimento da falta disciplinar, pela autoridade competente para instaurar o processo" (grifo nosso)

STJ MS 8998 (DJ: 09/12/2003) Relator: Gilson Dipp

Ementa: [...] V- Consoante entendimento jurisprudencial e nos termos do art. 142 e parágrafos da Lei no 8.112/90, não há a ocorrência da prescrição da pretensão punitiva da Administração se entre a data do conhecimento do fato pela autoridade competente e a da instauração do processo administrativo disciplinar contra o servidor não houve o transcurso de mais de cinco anos. IV - Ordem denegada.

Voto: [...] Na presente hipótese, consoante se verifica nos documentos acostados pelo impetrante, bem como nas informações prestadas, a autoridade competente para a instauração da ação disciplinar somente tomou conhecimento da existência de irregularidades em janeiro de 2003 (fl. 191). O processo administrativo disciplinar foi instaurado em março de 2003, sendo publicada a Portaria constituindo a Comissão processante para a apuração das denúncias. (grifo nosso)

Diante do posicionamento do Superior Tribunal de Justiça, necessário analisar outra questão presente no indigitado parágrafo $1^{\circ}$ do artigo 142 da Lei $\mathrm{n}^{\circ}$ 8.112/90; é que o dispositivo menciona que o prazo prescricional corre a partir do conhecimento do fato, sem mencionar por que autoridade.

Sendo assim o entendimento do Superior Tribunal de Justiça, exigindo que a autoridade competente para instaurar o processo disciplinar tome conhecimento do fato para só então o lapso prescricional ser iniciado parece pretender oficializar a imprescritibilidade!

Em resumo, a frágil opção legislativa acabou respaldada por entendimento pretoriano, que - não bastasse fazer tabula rasa da 
Constituição Federal ainda elaborou interpretação restritiva contra legem pois esta assim não procedeu, ao contrário, a lei estabelece o seguinte, litteris:

Art. 143. A autoridade que tiver ciência de irregularidade no serviço público é obrigada a promover a sua apuração imediata, mediante sindicância ou processo administrativo disciplinar, assegurada ao acusado ampla defesa.

Neste sentido veja-se a seguinte decisão:

TJ MS 11974 (DJ: 07/05/2007) Relator: Laurita Vaz

Ementa: 1.0 art. $142, \S 1 .^{\circ}$, da Lei n. $^{\circ} 8.112 / 90$ - o qual prescreve que "O prazo de prescrição começa a correr da data em que o fato se tornou conhecido"-, não delimita qual autoridade deverá ter obtido conhecimento do ilícito administrativo. Dessa forma, não cabe ao intérprete restringir onde o legislador não o fez. [Trecho do Voto: "Desta forma, é equivocada a conclusão do Parecer-AGU GQ-55] 2. Ademais, consoante dispõe o art. 143 da Lei n. ${ }^{\circ} 8.112 / 90$, qualquer autoridade administrativa que tomar conhecimento de alguma irregularidade no serviço público deverá proceder à sua apuração ou comunicá-la à autoridade que tiver competência para promovê-la, sob pena de responder pelo delito de condescendência criminosa. 3. Desse modo, é razoável entender-se que o prazo prescricional de cinco anos, para a ação disciplinar tendente à apuração de infrações puníveis com demissão ou cassação de aposentadoria, comece a correr da data em que autoridade da Administração tem ciência inequívoca do fato imputado ao servidor, e não apenas a partir do conhecimento das irregularidades pela autoridade competente para a instauração do processo administrativo disciplinar. 4. Na hipótese, admitida a ciência das irregularidades, pelo Superintendente Regional do INCRA, em maio de 1995 e sendo de 5 (cinco) anos o prazo para o exercício da pretensão punitiva do Estado, nos termos do art. 142, inciso I, da Lei n. ${ }^{\circ} 8.112 / 90$, resta configurada a prescrição, já que o processo administrativo disciplinar que culminou com a aplicação da pena de cassação de aposentadoria do ora Impetrante foi instaurado apenas em 28/03/2005. 5. Segurança concedida. (grifo nosso) 
Trata-se de decisão mais recente que, embora não traga luz a sobre a questão mais relevante, que é a insubsistência do parágrafo $1^{\circ}$ do artigo 142 da Lei $\mathrm{n}^{\circ} 8.112 / 90$, trata com mais profundidade a respeito do tema junto ao Superior Tribunal de Justiça.

Em que pesem todas as críticas, ainda é o Estatuto Federal a norma inspiradora da legislação dos demais entes da federação, que - em regra adotam o conhecimento do fato como dies a quo para fins prescricionais.

Exceção a regra é a legislação paulista (Lei Complementar $n^{\circ}$ 942/2003, cujo artigo 261 merece destaque.

Artigo 261 - Extingue-se a punibilidade pela prescrição:

I - da falta sujeita à pena de repreensão, suspensão ou multa, em 2 (dois) anos;

II - da falta sujeita à pena de demissão, de demissão a bem do serviço público e de cassação da aposentadoria ou disponibilidade, em 5 (cinco) anos;

III - da falta prevista em lei como infração penal, no prazo de prescrição em abstrato da pena criminal, se for superior a 5 (cinco) anos.

$\S 1^{\circ}$ - A prescrição começa a correr:

1 - do dia em que a falta for cometida;

2 - do dia em que tenha cessado a continuação ou a permanência, nas faltas continuadas ou permanentes.

$\S 2^{\circ}$ - Interrompem a prescrição a portaria que instaura sindicância e a que instaura processo administrativo.

$\S 3^{\circ}$ - O lapso prescricional corresponde:

1 - na hipótese de desclassificação da infração, ao da pena efetivamente aplicada;

2 - na hipótese de mitigação ou atenuação, ao da pena em tese cabível. $\S 4^{\circ}$ - A prescrição não corre:

1 - enquanto sobrestado o processo administrativo para aguardar decisão judicial, na forma do $\S 3^{\circ}$ do artigo 250 ;

2 - enquanto insubsistente o vínculo funcional que venha a ser restabelecido.

$\S 5^{\circ}$ - Extinta a punibilidade pela prescrição, a autoridade julgadora determinará o registro do fato nos assentamentos individuais do servidor. $\S 6^{\circ}$ - A decisão que reconhecer a existência de prescrição deverá desde logo determinar, quando for o caso, as providências necessárias à apuração da responsabilidade pela sua ocorrência. 
Em síntese, a prescrição no processo administrativo disciplinar não deve - pela melhor técnica jurídica - ser calculada a partir da data do conhecimento, mas sim da data do fato.

\subsection{Parágrafo $2^{\circ}$ do artigo 142 da Lei $n^{\circ} 8.112 / 90$.}

Menor dificuldade e polêmica oferece o tópico atual; mesmo porque a questão da diferenciação de responsabilidades já foi tratada na primeira parte do trabalho. Enquanto a sanção penal tem como finalidade reprimir os ilícitos considerados enquanto condutas nocivas à sociedade em geral; a sanção disciplinar tem preocupação precípua em reprimir condutas nocivas ao bom funcionamento da Administração Pública, o bem tutelado em cada uma das responsabilidades é diverso, impedindo sua confusão e possibilitando a apuração concomitante de ambas, cada qual em sua esfera, sujeitando-se o infrator a dois julgamentos distintos, cujas decisões são - em regra - incapazes adstritas a seu campo de atuação ${ }^{80}$.

Para que haja, no entanto aplicação da prescrição penal é necessária a efetiva apuração em sede penal, conforme jurisprudência dominante. ${ }^{81}$

${ }^{80}$ Há situações em que o julgamento penal vincula a decisão administrativa, como será visto.

${ }^{81}$ STJ ROMS 14420 (DJ: 30/09/2002) Relator: Vicente Leal

Ementa: [...] - Em sede de procedimento administrativo fundado em infração disciplinar que também configura tipo penal, o prazo de prescrição é aquele previsto na lei penal. - A mera presença de indícios de prática de crime sem a devida apuração nem formulação de denúncia, obsta a aplicação do regramento da legislação penal para fins de prescrição, devendo esta ser regulada pela norma administrativa. [...]

Voto: [...] É certo que, nos termos da legislação local (Lei Estadual n ${ }^{\circ} 10.098 / 94$, art. 197, § $2^{\circ}$ ), quando a infração administrativa também constituir crime deverá ser observada a lei penal para fins de prescrição. Todavia, é de se notar que no caso sub examen em nenhum momento foi oferecida denúncia por qualquer crime cometido pelo recorrente e sequer foi instaurado procedimento tendente a apurá-lo. Ora, se inexiste crime, descaracterizada está a aplicação do referido dispositivo legal, devendo ser aplicado, in casu, o prazo prescricional administrativo e não o penal. [...] A mera existência de indícios da prática de crime, sem a sua efetiva apuração ou oferecimento de denúncia afasta a aplicação da legislação penal para fins de prescrição, devendo esta ser regulada pela legislação administrativa, mais precisamente, a lei estadual no 10.098/94 (Estatuto dos Servidores Públicos Civis do Estado). (grifo nosso)

STJ MS 12090 (DJ: 21/05/2007) Relator: Arnaldo Esteves Lima

Ementa: [...] 1. Nos casos em que o suposto ilícito praticado pelo servidor público não for objeto de ação penal ou o servidor for absolvido, aplica-se o disposto na legislação administrativa quanto ao prazo prescricional. Precedentes. [...]

Voto: [...] Segundo consta dos autos, foi considerado o prazo prescricional de 12 (doze) anos, ao argumento de que os atos narrados seriam capitulados como crime de falsidade ideológica. A autoridade impetrada, inclusive, em suas informações, afirma que "a impetrante responde a ação penal por suposto delito de falsidade ideológica, ora pendente de julgamento, uma vez que teria inserido dados falsos em documento público, com a finalidade de alterar seu conteúdo e de viabilizar expedição de novo número de CPF para os contribuintes envolvidos" (fl.1.339). No entanto, essa afirmação não encontra respaldo na prova préconstituída apresentada. A certidão de fl. 1.034, emitida em 20/7/06, prova a inexistência de ação penal em desfavor da impetrante em curso perante a Justiça Federal no Distrito Federal. Nesse ponto, destaca-se a manifestação do Ministério Público Federal, da lavra da Subprocuradora-Geral da República GILDA 
No que diz respeito ao ilícito civil, a independência da recomposição patrimonial frente à responsabilidade criminal é preceito consagrado no direito ocidental, declarada na primeira parte do artigo 935 do Código Civil, não cabendo maiores discussões.

Como afirmado acima, a propalada independência entre as esferas de repressão se dá em princípio, não afastando de plano os efeitos da sentença penal. Isto decorre de um raciocínio muito singelo.

Qualquer punição possui dois antecedentes lógicos que são a materialidade do fato e a autoria. É evidente que só existirá ilícito se o fato realmente ocorreu (materialidade) e se o sujeito passivo do processo (civil, administrativo ou penal) for o autor. É teratológica a punição daquele que não foi o autor do fato ilícito ou se este mesmo fato nunca existiu.

Dito isto, em regra, a sentença penal absolutória por negativa de autoria ou por ausência de materialidade do fato sempre reflete nas esferas administrativa e civil, fundamentando o trancamento do processo administrativo disciplinar e até a reintegração do servidor demitido em razão do fato criminoso bem como excluindo a responsabilidade civil.

Entretanto, o réu pode ser absolvido por outros motivos expressos nos incisos do artigo 386 do Código de Processo Penal, verbis:

Art. 386. O juiz absolverá o réu, mencionando a causa na parte dispositiva, desde que reconheça:

I - estar provada a inexistência do fato;

II - não haver prova da existência do fato;

III - não constituir o fato infração penal;

IV - não existir prova de ter o réu concorrido para a infração

penal;

V - existir circunstância que exclua o crime ou isente o réu de pena;

VI - não existir prova suficiente para a condenação.

PEREIRA DE CARVALHO, que asseverou tão-somente a existência de Inquérito Policial em curso na Justiça Federal, mas não de ação penal, razão por que deve ser observado tão-somente o prazo prescricional previsto na Lei 8.112/90, consoante atesta o seguinte excerto (fls. 1.441/1.441v): [...] Por conseguinte, a capitulação dos ilícitos administrativos em exame como crime de falsidade ideológica partiu exclusivamente da Administração, sem respaldo em nenhuma ação penal. Segundo posicionamento adotado no Superior Tribunal de Justiça, nos casos em que o suposto ilícito praticado pelo servidor público não for objeto de ação penal ou o servidor for absolvido, aplica-se o disposto na legislação administrativa quanto ao prazo prescricional. [...] (grifo nosso) 
Destas causas, apenas as constantes dos incisos I e parte do inciso $\mathrm{V}$ podem ser alegadas em favor do servidor, pois as demais não afastam a responsabilidade - que, como sabido, decorre da violação de um dever jurídico originário. A parte do inciso $\mathrm{V}$ que interessa é a que se refere às causas de exclusão da ilicitude (estado de necessidade, legítima defesa, estrito cumprimento de dever legal ou exercício regular de direito11).

O artigo 65 do Código de Processo Penal, no título da reparação civil do ato ilícito, impõe ao juízo cível a observação da sentença penal que reconhecer uma das causas de exclusão de ilicitude. É óbvio que aquele que age licitamente não pode ser responsabilizado por nada. Toda e qualquer responsabilidade seja ela civil, administrativa, ou penal - decorre da inobservância de um dever jurídico. Ora, se a ação foi lícita - uma vez que o servidor agiu dentro do seu direito e sem abuso nada há a ser reparado, impedindo, portanto, qualquer punição.

Ainda neste título, o legislador positivou mais alguns critérios de ineficácia da sentença penal em outras esferas. Como já mencionado, a regra é que a responsabilidade fique adstrita àquele campo, como é reconhecido pela doutrina e pela jurisprudência. Destarte, temos os artigos 66 e 67 do CPP, verbis:

Art. 66. Não obstante a sentença absolutória no juízo criminal, a ação civil poderá ser proposta quando não tiver sido, categoricamente, reconhecida a inexistência material do fato.

Art. 67. Não impedirão igualmente a propositura da ação civil:

I - o despacho de arquivamento do inquérito ou das peças de informação;

II - a decisão que julgar extinta a punibilidade;

III - a sentença absolutória que decidir que o fato imputado não constitui crime.

Portanto, a sentença penal somente produz efeitos favoráveis ao servidor quando houver: negativa de autoria; inexistência do fato ou reconhecimento da licitude da conduta. 
É corrente que a chamada falta residual, ou resíduo administrativo, corresponde àquela conduta contrária ao dever de lealdade ${ }^{82}$ que, não obstante a absolvição penal dá ensejo à punição administrativa.

O Supremo Tribunal Federal tem entendimento sumulado a respeito do tema, a Súmula n ${ }^{\circ} 18$ possui a seguinte redação: pela falta residual, não compreendida na absolvição pelo juízo criminal, é admissível a punição administrativa do servidor público.

Pode ocorrer que o juízo criminal tenha absolvido com base na ausência de provas de que o servidor foi o autor do fato, ou por não existir prova suficiente para a condenação, ou por não estar provada a existência do fato, ou pelo fato não ser típico e, ainda assim, subsistir a punição administrativa. A que se deve tal proceder? Primeiro, a obrigatoriedade da observância da sentença penal em favor do servidor, conforme dito possui rol taxativo de hipóteses; em segundo, a falta ou insuficiência de provas para demonstrar o atingimento do bem jurídico tutelado penalmente não implica, necessariamente, em ausência de caracterização de violação do bem jurídico administrativamente resguardado, assim - repise-se - pode subsistir responsabilidade administrativa disciplinar. Deste modo, na falta residual, o "minus" que as autoridades administrativas apuraram, basta para condenar o servidor, administrativamente, amparado como legítimo e inatacável o ato administrativo ${ }^{83}$.

O importância da valoração das provas no processo administrativo, tal qual no direito processual penal é inegável. No entanto não é incompatível com o due process of law substantivo e formal a aplicação de penalidade administrativa fundamentada em indícios que no âmbito penal seriam insuficientes para dar azo a um decreto sancionatório. Neste sentido confira-se Fábio Medina Osório ${ }^{84}$, segundo que o Direito Administrativo é especialmente receptivo à prova indiciária, até porque essa modalidade de prova é fundamental no estabelecimento de pautas de "razoabilidade" dos julgamentos.

\footnotetext{
${ }^{82}$ TELLES, Antonio de Queiroz: Repercussão da sentença penal na esfera administrativa, São Paulo, RT, 2000, p. 365.

${ }^{83}$ Neste sentido pronuncia-se José Cretella Júnior em artigo intitulado Repercussão da sentença penal na esfera administrativa - RDP 17/43.

${ }^{84}$ Direito Administrativo sancionador, São Paulo, RT, 2000, p. 365.
} 
Assim, pode restar a mesma falta de provas no campo penal apta a ensejar punição no campo administrativo disciplinar, em falta residual. Sendo assim, torna-se inviável - por exemplo - cogitar o servidor em reintegração fundamentada em absolvição no campo penal. A independência das instâncias impera, de forma que apenas excepcionalmente e nos casos tratados poderá haver transposição de efeitos da decisão de um campo a outro.

Com relação à prescrição, a dicção do $\S 2^{\circ}$ do artigo 142 da Lei 8.112/90 excepciona a regra e leva a legislação penal a regulamentar os prazos dos ilícitos administrativos penais.

E os prazos da legislação penal são computados a partir da data do fato; sendo assim, nos ilícitos administrativos penais a prescrição administrativa deverá ter seu dies a quo estabelecido na mesma data que a da legislação penal, vale dizer, em regra na data do fato.

Como mencionado no início do tópico, o dispositivo não traz maiores polêmicas em si, mesmo porque a prescrição simultânea do delito tanto no campo penal quanto no administrativo é bastante lógica e adequada.

Porém, mais um argumento é lançado em desfavor do já debatido parágrafo $1^{\circ}$ do artigo 142 da Lei $n^{\circ}$ 8.112/90. É que o legislador - bem demonstrando a falta de técnica e precisão - criou uma contradição no próprio artigo, uma vez que se o servidor mediante duas condutas diversas na mesma data pratica dois ilícitos administrativos, um puro e outro penal, sendo o último muito mais grave, caso não haja o conhecimento dos fatos pela administração, o delito menos grave prescreverá ${ }^{85}$ depois do mais grave. Situação juridicamente contraditória e absurda.

Brasilino Pereira dos Santos $^{86}$ traz o seguinte exemplo:

Um exemplo prático poderá melhor elucidar o absurdo a que pode conduzir a norma administrativa que fixa o marco inicial da prescrição na data do conhecimento do fato: uma falta ética supostamente praticada em 1971, veio a ser punida em 1995, isto é, quase 23 anos depois, com a cassação do registro profissional de um profissional da medicina. A falta por ele cometida era apenas de natureza administrativa, isto é, o fato não correspondia igualmente a uma falta criminal. Se fosse o

\footnotetext{
${ }^{85}$ Talvez nem venha a prescrever, basta à autoridade não ter conhecimento que o prazo nem se iniciará...

${ }^{86}$ SANTOS, Brasilino Pereira dos. O prazo da prescrição de punição disciplinar começa a correr do momento em que o fato se tornou conhecido? . Jus Navigandi, Teresina, ano 5, n. 51, out. 2001. Disponível em: <http://jus2.uol.com.br/doutrina/texto.asp?id=2278>. Acesso em: 18 mai. 2008.
} 
crime mais grave que se pode imaginar, o prazo máximo da prescrição, segundo o Código Penal (art. 109, I) seria, como é, de 20 anos. A prescrição vintenária em sede criminal atinge qualquer crime cuja pena máxima seja superior a 12 anos de privação da liberdade.

A prescrição penal, como forma de extinção da punibilidade, pode ocorrer antes ou depois de transitar em julgado a sentença condenatória (art. 109 e 110 do CP). A contagem de cada uma delas é diferente, pois a primeira refere-se à pena in abstracto e a segunda à pena in concreto. Melhor dizendo, a prescrição antes de transitada em julgado a sentença condenatória vincula-se, na sua contagem, à pena prevista no tipo penal abstratamente, enquanto que a segunda forma de prescrição vincula-se à pena prevista no título judicial, ou seja, na sentença - após a dosimetria da pena. É o que decorre do texto legal:

Prescrição antes de transitar em julgado a sentença

Art. 109 - A prescrição, antes de transitar em julgado a sentença final, salvo o disposto nos $\S \S 1^{\circ}$ e $2^{\circ}$ do art.' 110 deste Código, regula -se pelo máximo da pena privativa de liberdade cominada ao crime, verificando-se: (Redação dada pela Lei n॰ 7.209, de 11.7.1984)

I - em 20 (vinte) anos, se o máximo da pena é superior a 12 (doze);

II - em 16 (dezesseis) anos, se o máximo da pena é superior a 8 (oito) anos e não excede a 12 (doze);

III - em 12 (doze) anos, se o máximo da pena é superior a 4 (quatro) anos e não excede a 8 (oito);

IV - em 8 (oito) anos, se o máximo da pena é superior a 2 (dois) anos e não excede a 4 (quatro);

$\mathrm{V}$ - em 4 (quatro) anos, se o máximo da pena é igual a 1 (um) ano ou, sendo superior, não excede a 2 (dois);

VI - em 2 (dois) anos, se o máximo da pena é inferior a 1 (um) ano

Prescrição depois de transitar em julgado sentença

final condenatória:

Art. 110 - A prescrição depois de transitar em julgado a sentença condenatória regula-se pela pena aplicada e verifica-se nos prazos fixados no artigo anterior, os quais se aumentam de um terço, se o condenado é reincidente. 
$\S 1^{\circ}$ - A prescrição, depois da sentença condenatória com trânsito em julgado para a acusação, ou depois de improvido seu recurso, regula-se pela pena aplicada.

$\S 2^{\circ}$ - A prescrição, de que trata o parágrafo anterior, pode ter por termo inicial data, anterior à do recebimento da denúncia ou da queixa.

Diante das duas possibilidades, qual seria a adequada para a contagem da prescrição no processo administrativo disciplinar? O da pena in abstracto ou in concreto?

A doutrina é pacífica com relação ao tema. A contagem se dará pela pena abstratamente considerada. E isto pela independência das instâncias.

A prescrição em se considerando a pena concretamente aplicada ao caso concreto dependerá da definitividade desta. Sendo assim necessário o trânsito em julgado da sentença penal condenatória, o que é incompatível com a independência da apuração em sede administrativa; a Administração não pode se ver obrigada a aguardar o término do processo criminal para só então proceder a responsabilização do acusado.

A ratio de dispositivos que vinculam a prescrição administrativa à do crime está na proteção do interesse público, uma vez que o lapso prescricional é praticamente sempre ampliado. Tal ampliação decorre da vinculação da punição administrativa à prescrição da pena in abstracto.

Entretanto, algumas exceções podem ser lembradas; Edmir Netto de Araújo cita a Lei $\mathrm{n}^{\mathrm{o}}$ 10.261, de 28 de outubro de 1968 que é o Estatuto dos Funcionários Públicos Civis do Estado de São Paulo, que expressamente traz possibilidade de aplicação da prescrição com fulcro na pena in concreto.

“Omissis...

Artigo 261 - Extingue -se a punibilidade pela prescrição:

$\cdots$

$\S 3^{\mathbf{o}}$ - O lapso prescricional corresponde: (NR)

1 - na hipótese de desclassificação da infração, ao da pena efetivamente aplicada; 
2 - na hipótese de mitigação ou atenuação, ao da pena em tese cabível.

- Redação dada pelo artigo $1^{\circ}$, III da Lei Complementar n ${ }^{\circ} 942$, de $06 / 06 / 2003$.

...” (grifamos)

Mas, como dito esta é uma exceção à regra da aplicação da pena in concreto para o cálculo da prescrição; e as exceções são possíveis, na medida em que há competência comum dos entes da federação para legislar sobre o tema.

Em síntese, reafirme-se: o ilícito pode a um só tempo gerar mais de uma espécie de responsabilidade, de acordo com o bem jurídico ofendido, podendo ter mais de uma punição aplicável, sem que isto constitua bis in idem; é possível a punição da infração administrativa (por alguns chamada de resíduo administrativo) ainda que haja absolvição na esfera penal; excepcionalmente há possibilidade de vinculação do processo administrativo à decisão penal, mas isto é exceção em casos taxativamente previstos; em regra se aplica a pena in abstracto para o cálculo da prescrição do ilícito administrativo penal.

\subsection{Prescrição retroativa.}

A prescrição retroativa é produto de uma construção pretoriana. O Supremo Tribunal Federal editou a Súmula 146, nos idos de 1961, com o seguinte verbete: "A prescrição da ação penal regula-se pela pena concretizada, quando não há recurso da acusação". Esse entendimento do Supremo fundamentou-se na redação original do art. 110, parágrafo único, do Código Penal de 1940, que, na ausência de recurso da acusação, impedia que a pena aplicada fosse elevada, devendo servir de base para o cálculo da prescrição. Nesse período, a nossa Corte Suprema passou a admitir que a prescrição incidisse sobre lapso temporal anterior à sentença condenatória e, inclusive, antes mesmo do recebimento da denúncia ou queixa. A prescrição retroativa leva em consideração, a pena aplicada, in concreto.

Tendo em vista ser espécie de prescrição, natural que possa ser considerada desde a consumação do delito, conforme previsão do Código Penal, desde a reforma de 1984; diz o $§ 1^{\circ}$, depois da sentença condenatória com trânsito em julgado para a acusação, ou depois de improvido seu recurso, regula-se pela pena aplicada. 
Por seu turno, reza o $\S 2^{\circ}$ que a prescrição, de que trata o parágrafo anterior, pode ter por termo inicial data anterior ao recebimento da denúncia ou da queixa. Essa previsão legal representa precisamente a instituição da prescrição retroativa, exatamente nos moldes da Súmula 146.

Em que pese à letra da lei determinar a aplicação dos prazos previstos na lei penal para os ilícitos administrativos penais, não se mostra adequada a utilização da prescrição intercorrente; mesmo que após julgada a questão no âmbito penal e aplicada a sanção estejam presentes os requisitos previstos no Código Penal para a utilização da prescrição retroativa. É que a pena aplicada em direito penal diz respeito à pena justa diante do bem jurídico lesado; em se tratando de direito administrativo disciplinar tal justeza pode não prosperar, pois o bem atingido foi outro e, possivelmente em outra dimensão. Sendo assim, não é adequado transportar o lapso prescricional calculado em uma pena concreta aplicada quando o delito atingiu um bem jurídico, para situação em que o bem atingido foi outro e, concretamente a pena aplicada pelo - ainda que pelo mesmo julgador (fato que só mencionamos a título didático) possível e provavelmente fosse outra, afinal na dosimetria da pena o bem atingido e em que grau é dos mais relevantes pontos a ser considerado.

\subsection{Prescrição intercorrente.}

A duração razoável do processo é norma constitucional assegurada no artigo 5॰ LXXVIII, bem como a existência de meios que garantam tramitação processual célere. A razoável duração do processo administrativo disciplinar é aquela estabelecida na própria Lei $\mathrm{n}^{\circ}$ 8.112/90 entre a defesa e o julgamento (140 dias).

Pelo ordenamento constitucional atual, a extrapolação de 140 dias da tramitação do processo administrativo disciplinar não pode mais possibilitar a interrupção indefinida da prescrição intercorrente, pois ela deverá ser contada do dia da ocorrência do fato investigado, com carência dos respectivos 140 dias.

Defender na atualidade a tese da suspensão da prescrição ou sua interrupção indefinidamente é inconstitucional, em face da garantia préexistente da celeridade processual, quer perante o Poder Judiciário, quer na esfera administrativa. 
Portanto, esta nova fase do direito público não mais comporta uma duração do processo administrativo disciplinar que não seja "razoável" e com a "celeridade de sua tramitação". Ou pelas palavras de Sérgio Bermudes ${ }^{87}$ : "A celeridade da tramitação traduz-se na presteza da prática de cada ato do processo, porquanto a demora na prática de um deles repercute, negativamente no conjunto, como acontece com a retenção de um trem num dos pontos de parada do seu percurso. Atos praticados celeremente asseguram a duração razoável senão rápida do processo, o qual outra coisa não é, desde a etimologia, que um conjunto de atos que se sucedem para a consecução de determinado fim."

O princípio é o da prescritibilidade dos atos ilícitos administrativos, visto que a Carta Federal ressalva apenas o ressarcimento ao erário, não se vinculando aos prazos, que deverão respeitar o instituto da prescrição. Dessa forma, a apuração e a punição do ilícito administrativo ficam prejudicadas "se a Administração não toma providência para sua apuração e responsabilização do agente, sua inércia gera a perda do seu jus persequendi." 88

A inércia da apuração ou da conclusão do processo administrativo disciplinar faz nascer a prescrição intercorrente para os administrados face a Administração.

O instituto da prescrição intercorrente no processo administrativo disciplinar é uma das consequências do princípio da segurança jurídica, que exige a manutenção da prescritibilidade.

Dessa maneira o STF mantendo-se fiel a este posicionamento não permite que a abertura de sindicância ou a instauração de processo disciplinar interrompa a prescrição eternamente, mesmo havendo norma legal que estabeleça o contrário $\left(\S \S 3^{\circ}\right.$ e $4^{\circ}$, do art. 142, da Lei $n^{\circ} 8.112 / 90$. Em especial, sobre a interrupção e a suspensão da prescrição, a que aludem os $\S \S 3^{\circ}$ e $4^{\circ}$, do art. 142, da Lei n ${ }^{\circ}$ 8.112/90, incidentes sobre o processo disciplinar, a Excelsa Suprema Corte seguiu o escorreito posicionamento do Min. Marco Aurélio, e que no RMS n ${ }^{\circ}$ 23.436/DF assim explicitou:

"Ora, cuida-se de institutos diversos quando se trata da interrupção e da suspensão. A primeira resulta, uma vez exaurido o ato que a motivou, em novo curso do prazo, desprezando-se os dias

${ }^{87}$ BERMUDES, Sérgio. A Reforma do Judiciário pela Emenda Constitucional $n^{o} 45$. Rio de Janeiro, Forense, 2005, p. 11.

${ }^{88}$ SILVA, José Afonso da, Comentário Contextual à Constituição. São Paulo, Malheiros, 2005, p. 348. 
transcorridos. Já a suspensão conduz à permanência no tempo enquanto não afastada a respectiva causa, computando-se os dias transcorridos até então e que, assim, devem ser somados aos que sobejarem. Por outro lado, não se coaduna com o nosso sistema constitucional, especialmente no campo das penas, sejam de índole criminal ou administrativa, exceto relativamente ao crime revelado pela ação de grupos armados, civis ou militares, contra a ordem constitucional e o Estado democrático - inciso XLIV do art. $5^{\circ}$, da CF/88, a inexistência de prescrição. Inconcebível é que se entenda, interpretando os preceitos da Lei $\mathrm{n}^{\circ} 8.112$, de 11 de dezembro de 1990, que, uma vez aberta a sindicância ou instaurado o processo disciplinar, não se cogite mais, seja qual foi o tempo que se leve para a conclusão do feito, da incidência da prescrição. É sabido que dois valores se fazem presentes: o primeiro, alusivo à Justiça, a direcionar a possibilidade de ter-se o implemento a qualquer instante; já o segundo está ligado à segurança jurídica, à estabilidade das relações e, portanto, à própria paz social que deve ser restabelecida num menor tempo possível. Não é crível que se admita encerrar a ordem jurídica verdadeira espada de Dâmocles a desabar sobre a cabeça do servidor a qualquer momento."

Esta regra pacificada pelo STF estabelece a prescrição intercorrente no processo administrativo disciplinar, tendo em vista ser ilegal a interrupção do prazo prescricional, que "começa a correr de novo e por inteiro a partir do próprio fato interruptivo, à semelhança de como sucede no direito penal."

Por igual, a suspensão indefinida da prescrição não pode prevalecer em nenhum país que pretenda ter na democracia um de seus pilares.

Assim, o STF afastou a eficácia do parágrafo $3^{\circ}$, do art. 142, da Lei $\mathrm{n}^{\circ}$ 8.112/90, por entender que a respectiva interrupção nele prevista, cessa uma vez ultrapassado o período de 140 dias alusivo a conclusão do procedimento disciplinar e a aplicação da pena (arts. 152 e 167 da citada lei), como se verifica na ementa do julgamento do RMS no 23436/DF: "Prescrição - Processo Administrativo - Interrupção. A interrupção prevista no $\S 3^{\circ}$ do artigo 142 da Lei ${ }^{\circ}$ 8.112, de 11 de dezembro de 1990, cessa uma vez ultrapassado o período de 140 dias alusivo à conclusão do processo disciplinar e à imposição de pena - artigos 152 e 167 da referida Lei - voltando a ter curso, na integralidade, o prazo prescricional. Precedente: Mandado de Segurança n ${ }^{\circ}$ 22.7281/PR, Pleno, Relator Ministro Moreira Alves, acórdão publicado no Diário da Justiça de 13 de novembro de 1998."

Ora, o princípio é o mesmo para o $\S 1^{\circ}$, do art. 142 , da Lei em comento, tendo em vista que a interrupção prevista, até a ciência da 
Administração Pública do fato investigado, cessa uma vez ultrapassado o período de 140 dias para o julgamento do processo administrativo disciplinar.

Essa é a consequência lógica da prescrição intercorrente reconhecida pelo STF, em razão de não ser admitida a interrupção do prazo da prescrição eternamente.

Tal qual a regra do $\S 3^{\circ}$, o $\S 1^{\circ}$, do mesmo artigo 142 , da Lei $n^{\circ} 8.112 / 90$, pela interpretação do STF, é atingido pela prescrição intercorrente após os 140 dias entre a instauração e o julgamento do processo administrativo disciplinar. Ou seja, a Administração Pública, se a pena da infração disciplinar for a de demissão, cassação de aposentadoria ou disponibilidade e destituição de cargo em comissão, terá 140 dias corridos como interrupção da prescrição, tempo suficiente para o poder público tomar conhecimento de irregularidades, voltando a fluir o prazo prescricional normalmente.

Esta é a regra de coerência fixada pelo STF, pois não se admite uma interpretação restritiva ao instituto da prescrição intercorrente, tal qual vigente também no direito penal.

Tanto a esfera administrativa como a penal são destinatárias da prescrição intercorrente, segundo o estipulado pelo STF.

Dessa forma, o fluxo da prescrição volta a correr por inteiro se a Administração Pública não instaurar o processo administrativo disciplinar após 140 dias da data do fato tido como irregular. Assim, o dies a quo do prazo de prescrição da falta disciplinar, que não possua correlação com ilícito criminal, segundo o STF é de 140 dias, contados do dia do cometimento do ato investigado.

Nesse sentido, segue o seguinte julgado: "Cassação de aposentadoria pela prática, na atividade, de falta disciplinar punível com demissão (L. 8.112/90, art. 134): constitucionalidade, sendo irrelevante que não a preveja a Constituição e improcedente a alegação de ofensa do ato jurídico perfeito. II. Presidente da República: competência para a demissão de servidor de autarquia federal ou a cassação de sua aposentadoria. III. Punição disciplinar: prescrição: a instauração de o processo disciplinar interrompe o fluxo da prescrição, que volta a correr por inteiro se não decidido no prazo legal de 140 dias, a partir do termo final desse último. IV. Processo administrativodisciplinar: congruência entre a indiciação e o fundamento da punição aplicada, que se verifica a partir dos fatos imputados e não de sua capitulação legal."

A interpretação analógica desses julgados voltados para o $\S 3^{\circ}$, do art. 142 , da Lei $n^{\circ} 8.112 / 90$, direciona-se também para o seu parágrafo 
primeiro, pois a partir do momento em que foi estabelecida a possibilidade jurídica da existência de prescrição intercorrente do processo administrativo disciplinar, quando o assunto é a interrupção do dies a quo, pois a regra é a da prescritibilidade e não a da indefinição ad aeternum.

Portanto, a norma estabelecida no parágrafo $1^{\circ}$, do art. 142, da Lei $\mathrm{n}^{\circ}$ 8.112/90, merece moderada interpretação, sob pena de tornar imprescritível a falta disciplinar, até que a Administração Pública declare o seu conhecimento pleno ao fato investigado.

A elasticidade promovida pelo $\S 1^{\circ}$, do art. 142 , da lei em tela é inconcebível, pois a regra é justamente a inversa, ou seja, é a da prescrição intercorrente.

Dessa maneira, é inadmissível a interrupção da prescrição indefinidamente, pois tal situação é afrontosa ao princípio básico do Estado de Direito.

\subsection{Prescrição e decadência.}

Segundo Rafael Munhoz de Mello, a prescrição atinge direitos subjetivos que correspondem a uma prestação da outra parte da relação jurídica (fazer algo, não fazer, dar). Ofendido o direito, com o descumprimento da prestação, nasce para seu titular a pretensão, entendida justamente como poder de exigir de outrem uma prestação. A lei estabelece prazo para o exercício da pretensão, que, uma vez ultrapassado, impede que o titular do direito exija da outra parte a prestação devida. Não há, aqui, a extinção do direito, mas sim da pretensão - o que significa dizer que a prestação devida deixa de ser exigível. Muito embora se torne inexigível, o direito à prestação não é extinto pelo decurso do prazo, razão pela qual o ordenamento jurídico tutela e reconhece seu cumprimento espontâneo (por exemplo, o pagamento de dívida prescrita prevista no art. 882 do Código Civil).

Prosseguindo o autor, há outras situações em que o ordenamento jurídico estabelece prazo não para o exercício da pretensão, mas sim para o exercício de algum direito. Não se trata mais da exigibilidade de uma prestação que foi descumprida, mas, sim, da possibilidade de exercer um direito ou um poder que vai 
produzir efeitos na esfera jurídica de outrem. Encerrado o prazo extingue-se o direito, que já não mais pode ser exercido. Opera-se, então, a decadência ou caducidade ${ }^{89}$.

A partir daí conclui que a prescrição administrativa é em verdade decadência. Respeitando o posicionamento, respaldado por diversos autores, esclarecemos concordar com todas as definições e premissas, discordando da conclusão. E isto porque o citado autor aduz que não há ação, mas sim direito de punir.

Para responder a este posicionamento invocamos as palavras de Edmir Netto de Araújo em seu Curso de Direito Administrativo, $3^{\text {a }}$ ed, São Paulo, Saraiva, 2007, p. 950, 951.

Mas, na verdade, existe ação para a punição administrativa (veja-se, p. ex., o art. 142 da Lei 8.112/90, que fala expressamente em ação disciplinar), embora apenas na esfera administrativa em caso de ilícito administrativo puro, mas também na esfera penal no caso de falta-crime. Aliás, a ação (processo administrativo, inquérito administrativo, sindicância) é obrigatória para apuração e punição disciplinar, em razão do princípio do due process of Law (devido processo legal), invariavelmente agasalhado no direito positivo brasileiro (inclusive constitucional), $e$ também pela Administração.

Por outro lado, como o prazo de decadência não se interrompe, o que é possibilitado pelos Estatutos em relação à prescrição (pela instauração da ação administrativa), parece claro que estamos mesmo tratando de prescrição e não de decadência: o Estado deixa de punir não porque perde esse direito pelo decurso do prazo legal, mas porque perde o direito de processar em razão de sua inércia no prazo prescricional.

\subsection{Suspensão e interrupção dos prazos.}

Segundo o parágrafo $3^{\circ}$ do artigo 142 da Lei 8.112/90 a abertura de sindicância ou a instauração de processo disciplinar interrompe a prescrição, até a decisão final.

De se notar que apenas a sindicância disciplinar, e não a apenas investigativa dará azo à interrupção ${ }^{90}$. Somente os procedimentos de apuração que

${ }^{89}$ MELLO, Rafael Munhoz de: Princípios constitucionais de direito administrativo, São Paulo, Malheiros, 2007, p. 253. 
têm a capacidade de infligir penalidade ao servidor e que, portanto, devem respeitar os princípios da ampla defesa e do contraditório, são causas interruptivas da prescrição. A interrupção pode ocorrer uma única vez ma diç̧ão da legislação federal, bem como na visão de alguns doutrinadores.

Entretanto a legislação paulista, elogiada pela doutrina pela sua técnica, prevê - acertadamente - dois momentos de possível interrupção. De acordo com o parágrafo $2^{\circ}$, do artigo 261 da Lei 10.261, interrompem a prescrição a portaria que instaura sindicância e a que instaura processo administrativo.

Já a suspensão do prazo se dará em virtude de existência ou propositura de ação judicial apta a sobrestar o feito ${ }^{91}$.

${ }^{90}$ STJ ROMS 10316 (DJ: 22/05/2000) Relator: Vicente Leal

Ementa: [...] A sindicância que interrompe o fluxo prescricional é aquela realizada como meio sumário de apuração de faltas e aplicação de penalidades outras que não a demissão, e não o procedimento meramente apuratório e esclarecedor de fatos, desprovido do contraditório e da ampla defesa e que não dispensa a posterior instauração do processo administrativo. [...] (grifo nosso)

\section{AgRg no MS No 13.072 RELATOR : FELIX FISCHER}

EMENTA: [...] I - A sindicância só interromperá a prescrição quando for meio sumário de apuração de infrações disciplinares que dispensam o processo administrativo disciplinar. Quando, porém, é utilizada com a finalidade de colher elementos preliminares de informação para futura instauração de processo administrativo disciplinar, esta não tem o condão de interromper o prazo prescricional para a administração punir determinado servidor, até porque ainda nesta fase preparatória não há qualquer acusação contra o servidor. Precedente. (grifo nosso)

${ }^{91}$ STJ MS 7095 (DJ: 14/04/2003) Relator: Gilson Dipp

Ementa: [...] I- Não procede a tese calcada na incidência da prescrição punitiva da Administração, quando a demora na conclusão do processo decorre, exclusivamente, de atos procrastinatórios intentados pelo próprio servidor. Desta forma, não é correto imputar ao ente público ônus a que não deu causa. [...]

Voto: [...] Quanto aos pontos arguidos na exordial, não procede a alegação de prescrição por inércia da Administração, pois a demora na conclusão do processo não ocorreu por culpa da Administração, mas, ao contrário, pela suspensão do seu andamento, em decorrência dos vários pedidos de sobrestamento formulados pela própria impetrante, especialmente nas ações judiciais por ela intentadas, com vistas a procrastinar o compêndio administrativo. Dentre as ações mencionadas, sobressaem as seguintes: [...], sendo certo que o trânsito em julgado do último ocorreu aos 31 de outubro de 1997. [...] (grifo nosso)

STJ MS 9568 (DJ: 02/08/2006) Relator: Arnaldo Esteves Lima

Ementa: [...] 4. Diante do fato de que a Administração restou impedida de aplicar a pena de demissão ao impetrante até o trânsito em julgado do acórdão em referência, que reformou a sentença concessiva da segurança, não há falar em ocorrência da prescrição da pretensão punitiva do Estado e de aplicação da "teoria do fato consumado" para justificar a reintegração do servidor no cargo. 5. Segurança denegada. 
Como sabido, cessada a interrupção o prazo volta a correr in totum, desprezando o lapso até então transcorrido, ao passo que na suspensão o prazo retomará seu curso descontando-se o tempo já computado.

\subsection{Graça, anistia e indulto.}

\subsubsection{Graça.}

A graça em sentido amplo é o direito de agraciar e gênero dos institutos que concedem clemência que são das seguintes espécies: graça stricto sensu; anistia e indulto ${ }^{92}$.

As medidas de clemência têm o condão de perdoar as infrações, com o arquivamento dos processos, a suspensão da execução das penas em cumprimento e o cancelamento dos efeitos das já cumpridas.

Em sentido estrito, a graça é um ato de clemência soberana individual para indivíduo já condenado. É de competência do Presidente da República, nos termos do artigo 84, XII, da Constituição Federal.

Usualmente é utilizado o termo indulto individual, pois, conforme leciona Edmir Netto de Araújo, as autoridades possuem certa aversão ao termo graça... Trata-se de instituto plenamente aplicável ao direito administrativo disciplinar, porém, como de competência exclusiva do Presidente da República só se aplica no âmbito da jurisdição administrativa deste, sob pena de ilegal interferência deste em outro Poder ou ente federado.

\subsubsection{Anistia.}

A anistia outro ato de clemência soberana, porém de competência do Congresso Nacional, com a sanção do Presidente da República.

\footnotetext{
Voto: [...] Todavia, na hipótese, a contagem do prazo prescricional não se dará a partir da instauração do processo administrativo, uma vez que a Administração se viu impedida de aplicar a pena de demissão ao impetrante em razão de decisão judicial proferida em primeira instância nos autos do já citado Mandado de Segurança $\mathbf{n}^{\mathbf{8}} \mathbf{8 9 . 0 0 0 3 8 8 7 - 7}$, impedimento este que perdurou até o trânsito em julgado do acórdão que julgou a Apelação 92.01.25482-2-DF, que denegou a segurança, ocorrido em 25/2/2003 (fl. 213). (grifo nosso)
}

${ }^{92}$ CRETELLA JÚNIOR, José: Prática do processo administrativo, 6 ${ }^{\mathrm{a}}$ ed, São Paulo, RT, 2007, p.102. 
Possui caráter genérico e interpretação restritiva, aplicando-se a todos os inseridos, porém em interpretação que não permite analogias ou extensões, impondo-se a literalidade.

Tendo em vista a não proibição legal para aplicação da anistia em âmbito administrativo disciplinar, é admissível a sua existência; devendo sempre ser restritivamente interpretada para que não haja excessos.

Deverá, como dito, ser concedida pelo Presidente da República, sem possibilidade de sua aplicação pelos estados e municípios.

A anistia em direito penal abrange as penas administrativas apenas se estas forem acessórias da penalidade criminal; para que haja aplicação no campo do direito administrativo disciplinar é necessária a especificidade da lei concessiva.

Sobre tal ponto, pronuncia-se Edmir Netto de Araújo: tudo se resume ao que a lei disser. E, para nós, não é ilegal a concessão de anistia exclusivamente na área disciplinar, pois o dispositivo legal que a regula (art. 48, VIII, CF) fala, genericamente, em "concessão de anistia", não especificando seu campo.

E diante da competência para concessão ser ato complexo envolvendo os Poderes Legislativo e Judiciário, remata o referido autor: $a$ anistia administrativa, mesmo assim, é realmente uma intromissão do Poder Legislativo nos serviços administrativos, como de uma das pessoas políticas nas demais, causando desordem aos princípios hierárquicos, não sendo aconselhável sua concessão para faltas administrativas a não ser em caráter excepcional, em casos especialíssimos, e nos estritos limites da lei (ou dispositivo constitucional) concessiva, não sendo admissível qualquer interpretação analógica da norma concessiva. ${ }^{93}$

Em síntese, a norma concessiva deverá ser explícita e minuciosa, sob pena de se tornar inapta aos seus objetivos.

\subsubsection{Indulto.}

A última manifestação de clemência soberana é o indulto, que tal qual a anistia possui aplicação genérica, para todos os que reúnam as condições do decreto concessivo, que é de competência exclusiva do Presidente da

\footnotetext{
${ }^{93}$ ARAÚJO, Edmir Netto de, Curso de Direito Administrativo, $3^{\text {a }}$ ed, São Paulo, Saraiva, 2007, p. 946/947.
} 
República. Assemelha-se também ao instituto da graça, uma vez que se aplica apenas aos condenados, tendo em vista seu caráter genérico, se aplicam todas as considerações feitas com relação à anistia; porém dado o caráter de sua competência ser exclusiva do Presidente da República, necessário que se diga que, tal qual a graça, não pode ser aplicado fora do âmbito de jurisdição administrativa deste, sob pena de ferir a separação dos poderes (se no âmbito federal) ou o pacto federativo (se no âmbito dos outros entes federados), respeitados estes termos pode vir a ser aplicado no âmbito administrativo disciplinar.

Por derradeiro, saliente-se que as medidas de clemência devem ser adotadas com cautela uma vez que podem vir a causar não só desprestígio para o poder disciplinar como influência externa decisiva no processo administrativo, o que é desaconselhável.

\subsection{Redução dos prazos da prescrição.}

Interessante questão que surge é acerca da possibilidade de aplicação da redução dos prazos prescricionais do artigo 115 do Código Penal, que prevê redução de metade do lapso prescricional quando o acusado era ao tempo do fato menor de 21 anos ou quando do julgamento maior de 70 anos.

Tendo em vista que o comando legal determina a aplicação nos ilícitos administrativos penais dos prazos da lei penal, e que este (prazo prescricional reduzido) é um prazo da lei penal, entende-se que perfeitamente aplicável ao processo administrativo disciplinar. Com relação ao menor de 21 anos, trata-se de menoridade traduzida em lei de fins penais, pouco importando se há maioridade civil; e com relação ao maior de 70 anos, nem se argumente que não existirão pessoas na administração com tal idade, dada a compulsoriedade legal de aposentadoria; não há de se esquecer que - conforme sustentado na segunda parte deste trabalho - a responsabilidade administrativa disciplinar é atribuída àqueles que tenham vínculo jurídico com a Administração, não apenas servidores, que os sujeitem ao poder sancionador. Sendo assim, pessoas comissionadas maiores de 70 anos poderão vir a responder processo administrativo disciplinar. 
Fundamentamos a posição da aplicabilidade do artigo 115 do Código Penal, não só nos argumentos de ordem lógica acima expostos, mas também nas palavras de Emilio Betti, para quem o labor de interpretação das normas jurídicas deve buscar a sua vontade, o conteúdo de seu comando ou preceito, o que deve ser obtido por meio da identificação do ponto de relevância hermenêutica de cada item e dela mesma, consistente na essência de sua vontade, ou seja, o que a norma quer hoje, porque hoje é que está sendo cumprida, respeitada a coerência com o sistema. Sem se esquecer, porém, no plano da conclusão, a possibilidade de a interpretação ser extensiva (ou analógica) ou restritiva, tendo em vista a vontade da lei. ${ }^{94}$

\section{Legislação.}

Com o fito de facilitar a consulta e comparação transcrevemos a legislação que regra a prescrição aplicável à maior parte daqueles que podem sofrer processos administrativos disciplinares.

\subsection{Legislação Federal.}

Lei $\mathrm{n}^{\circ} 8.112$ de 11 de dezembro de 1990, que dispõe sobre o regime jurídico dos servidores públicos civis da União, das autarquias e das fundações públicas federais.

Art. 142. A ação disciplinar prescreverá:

I - em 5 (cinco) anos, quanto às infrações puníveis com demissão, cassação de aposentadoria ou disponibilidade e destituição de cargo em comissão;

II - em 2 (dois) anos, quanto à suspensão;

III - em 180 (cento e oitenta) dias, quanto á advertência.

$\S 1^{0}$ O prazo de prescrição começa a correr da data em que o fato se tornou conhecido.

$\S 2^{0}$ Os prazos de prescrição previstos na lei penal aplicam-se às infrações disciplinares capituladas também como crime.

\footnotetext{
94 BETTI, Emilio: Interpretazione dela legge e degli atti giuridici, Milano: Giuffrè, 1971, e Teoria geral do
} negócio jurídico, tradução de Fernando de Miranda, Coimbra: Coimbra Ed., 1979. 
$\S 3^{0}$ A abertura de sindicância ou a instauração de processo disciplinar interrompe a prescrição, até a decisão final proferida por autoridade competente.

$\S 4^{0}$ Interrompido o curso da prescrição, o prazo começará a correr a partir do dia em que cessar a interrupção.

\subsection{Legislação paulista.}

Lei $\mathrm{n}^{\circ} 10.261$, de 28 de outubro de 1968, que é o Estatuto dos Funcionários Públicos Civis do Estado de São Paulo. prescrição:

Art. 261 - Extingue -se a punibilidade pela

I - da falta sujeita à pena de repreensão, suspensão ou multa, em 2 (dois) anos;

II - da falta sujeita à pena de demissão, de demissão a bem do serviço público e de cassação da aposentadoria ou disponibilidade, em 5 (cinco) anos;

III - da falta prevista em lei como infração penal, no prazo de prescrição em abstrato da pena criminal, se for superior a 5 (cinco) anos.

$\S \mathbf{1}^{\mathbf{0}}$ - A prescrição começa a correr:

1 - do dia em que a falta for cometida;

2 - do dia em que tenha cessado a continuação ou a permanência, nas faltas continuadas ou permanentes.

$\S \mathbf{2}^{\mathbf{0}}$ - Interrompem a prescrição a portaria que instaura sindicância e a que instaura processo administrativo.

$\S \mathbf{3}^{\mathbf{0}}$ - O lapso prescricional corresponde:

1 - na hipótese de desclassificação da infração, ao da pena efetivamente aplicada;

2 - na hipótese de mitigação ou atenuação, ao da pena em tese cabível.

$\S \mathbf{4}^{\mathbf{0}}$ - A prescrição não corre:

1 - enquanto sobrestado o processo administrativo para aguardar decisão judicial, na forma do $\S 3^{\circ}$ do artigo 250 ;

2 - enquanto insubsistente o vínculo funcional que venha a ser restabelecido.

$\S \mathbf{5}^{\mathbf{0}}$ - Extinta a punibilidade pela prescrição, a autoridade julgadora determinará o registro do fato nos assentamentos individuais do servidor.

$\$ 6^{0}$ - A decisão que reconhecer a existência de prescrição deverá desde logo determinar, quando for o caso, as providências necessárias à apuração da responsabilidade pela sua ocorrência. 


\subsection{Legislação paulistana.}

Lei $\mathrm{n}^{\circ}$ 8.989, de 29 de outubro DE 1979, que é o Estatuto dos Funcionários Públicos do Município de São Paulo.

Art. 196 - Prescreverá:

I - em 2 (dois) anos, a falta que sujeite às penas de repreensão ou suspensão;

II - em 5 (cinco) anos, a falta que sujeite às penas de demissão, demissão a bem do serviço público e de cassação de aposentadoria ou disponibilidade.

Parágrafo único - A falta também prevista como crime na lei penal prescreverá juntamente com ele, aplicando-se ao procedimento disciplinar, neste caso, os prazos prescricionais estabelecidos no Código Penal, quando superiores a 5 (cinco) anos.

Art. 197 - Nas hipóteses dos incisos I e II do artigo anterior, a prescrição começa a correr da data em que a autoridade tomar conhecimento da existência da falta.

$\S 1^{\circ}-\mathrm{O}$ curso da prescrição interrompe-se pela abertura do competente procedimento administrativo.

$\S 2^{\circ}$ - Na hipótese do parágrafo anterior, todo o prazo começa a correr novamente, do dia da interrupção.

\section{Jurisprudência acerca da prescrição no processo administrativo}

\section{disciplinar.}

\section{INTERRRUPÇÃO POR SINDICÂNCIA:}

STJ ROMS 10316 (DJ: 22/05/2000) Relator: Vicente Leal

Ementa: [...] A sindicância que interrompe o fluxo prescricional é aquela realizada como meio sumário de apuração de faltas e aplicação de penalidades outras que não a demissão, e não o procedimento meramente apuratório e esclarecedor de fatos, desprovido do contraditório e da ampla defesa e que não dispensa a posterior instauração do processo administrativo. [...] (grifo nosso)

AgRg no MS No 13.072 RELATOR: FELIX FISCHER

EMENTA: [...] I - A sindicância só interromperá a prescrição quando for meio sumário de apuração de infrações disciplinares que dispensam o processo administrativo disciplinar. Quando, porém, é utilizada com a finalidade de colher elementos preliminares de informação para futura instauração de processo administrativo disciplinar, esta não tem o condão de interromper o prazo prescricional para a 
administração punir determinado servidor, até porque ainda nesta fase preparatória não há qualquer acusação contra o servidor. Precedente. (grifo nosso)

DIES A QUO:

STJ MS 6547 (DJ: 23/04/2001) Relator: Felix Fischer

Voto: [...] Ocorre que, conforme dispõe o $\S 1^{\circ}$ do art. 142 acima indicado, o prazo começa a correr da data em que o fato se tornou conhecido. Em vista dessa disposição expressa, não se pode considerar como dies a quo do lapso prescricional o dia em que foi concedido o benefício, porque nessa ocasião não foi constatada ainda a infração. In casu, deve-se considerar como o momento em que se tomou conhecimento da infração a data em que a autoridade competente para instaurar o processo soube da falta disciplinar, $[. .$. (grifo nosso)

STJ MS 8251 (DJ: 14/04/2003) Relator: Jorge Scartezzini

Ementa: [...] 1 - Não há que se falar em ocorrência da prescrição da pretensão punitiva disciplinar, tendo em vista que o prazo prescricional começou a fluir do momento em que a Administração tomou conhecimento da infração; no caso, da data em que a autoridade competente para instaurar o processo soube da falta disciplinar. [...] (grifo nosso)

STJ MS 8595 (DJ: 07/04/2003) Relator: Felix Fischer

Voto: [...] Ocorre que, conforme dispõe o $\S 1^{\circ}$ do art. 142 acima indicado, o prazo começa a correr da data em que o fato se tornou conhecido. Em vista dessa disposição expressa, não se pode considerar como dies a quo do lapso prescricional o dia em que foi concedido o benefício ou praticados os atos que ensejaram a sua cassação, porque nessa ocasião não foi constatada ainda a infração. In casu, deve-se considerar como o momento em que se tomou conhecimento da infração a data em que a autoridade competente para instaurar o processo soube da falta disciplinar, em 10/04/2001 (fls. 43 e 51/52). Nesse sentido é a lição de FRANCISCO XAVIER DA SILVA GUIMARÃES (Regime Disciplinar do Servidor Público Civil da União, Forense, 1998, p. 165): "Com efeito, se a prescrição extingue o direito de punir administrativamente, em razão de decurso de prazo legal, por inércia ou negligência, só se caracterizará a partir do conhecimento da falta disciplinar, pela autoridade competente para instaurar o processo" (grifo nosso)

STJ MS 8998 (DJ: 09/12/2003) Relator: Gilson Dipp

Ementa: [...] V- Consoante entendimento jurisprudencial e nos termos do art. 142 e parágrafos da Lei no 8.112/90, não há a ocorrência da prescrição da pretensão punitiva da Administração se entre a data do conhecimento do fato pela autoridade competente e a da instauração do processo administrativo disciplinar contra o servidor não houve o transcurso de mais de cinco anos. IV - Ordem denegada. 
Voto: [...] Na presente hipótese, consoante se verifica nos documentos acostados pelo impetrante, bem como nas informações prestadas, a autoridade competente para a instauração da ação disciplinar somente tomou conhecimento da existência de irregularidades em janeiro de 2003 (fl. 191). O processo administrativo disciplinar foi instaurado em março de 2003, sendo publicada a Portaria constituindo a Comissão processante para a apuração das denúncias. (grifo nosso)

STJ MS 11974 (DJ: 07/05/2007) Relator: Laurita Vaz

Ementa: 1.0 art. 142, $\$ 1 .^{\circ}$, da Lei n. $^{\circ} 8.112 / 90$ - o qual prescreve que "O prazo de prescrição começa a correr da data em que o fato se tornou conhecido"-, não delimita qual autoridade deverá ter obtido conhecimento do ilícito administrativo. Dessa forma, não cabe ao intérprete restringir onde o legislador não o fez. [Trecho do Voto: "Desta forma, é equivocada a conclusão do Parecer-AGU GQ-55] 2. Ademais, consoante dispõe o art. 143 da Lei ${ }^{\circ}{ }^{\circ} 8.112 / 90$, qualquer autoridade administrativa que tomar conhecimento de alguma irregularidade no serviço público deverá proceder à sua apuração ou comunicá-la à autoridade que tiver competência para promovê-la, sob pena de responder pelo delito de condescendência criminosa. 3. Desse modo, é razoável entender-se que o prazo prescricional de cinco anos, para a ação disciplinar tendente à apuração de infrações puníveis com demissão ou cassação de aposentadoria, comece a correr da data em que autoridade da Administração tem ciência inequívoca do fato imputado ao servidor, e não apenas a partir do conhecimento das irregularidades pela autoridade competente para a instauração do processo administrativo disciplinar. 4. Na hipótese, admitida a ciência das irregularidades, pelo Superintendente Regional do INCRA, em maio de 1995 e sendo de 5 (cinco) anos o prazo para o exercício da pretensão punitiva do Estado, nos termos do art. 142, inciso I, da Lei n. ${ }^{\circ}$ 8.112/90, resta configurada a prescrição, já que o processo administrativo disciplinar que culminou com a aplicação da pena de cassação de aposentadoria do ora Impetrante foi instaurado apenas em 28/03/2005. 5. Segurança concedida. (grifo nosso)

\section{CONHECIMENTO DA INFRAÇÃO:}

STJ MS 8259 (DJ: 17/02/2003) Relator: Hamilton Carvalhido

Ementa: [...] 11. Os fatos atribuídos ao impetrante, apesar de terem sido praticados há vários anos, só foram conhecidos pela Administração Pública após a conclusão do Relatório de Correição $n^{\circ}$ 016/2001, em 27 de abril de 2001. A portaria instauradora do processo administrativo disciplinar (Portaria Conjunta $\mathrm{n}^{\circ}$ 50) foi publicada em 19 de outubro de 2001, interrompendo o curso da prescrição, [...]. (grifo nosso)

STJ MS 12533 (DJ: 01/02/2008) Relator: Arnaldo Esteves Lima

Ementa: [...] 2. No tocante à prescrição, a Administração tomou conhecimento dos supostos ilícitos disciplinares em junho de 2000, quando sobreveio relatório da equipe de auditoria do INSS. Por meio da Portaria/INSS/CORRGOI n ${ }^{\circ} 479$, de 18/10/04, foi instaurado o processo administrativo disciplinar, oportunidade em que houve interrupção 
do prazo prescricional. A contagem voltou a ter curso por inteiro após 140 (cento e quarenta) dias da abertura dos trabalhos, conforme orientação jurisprudencial do Supremo Tribunal Federal. Assim, não houve a prescrição da pretensão punitiva do Estado, porquanto o ato de demissão da impetrante foi publicado no Diário Oficial de 1\%/12/06. [...] (grifo nosso)

\section{INTERRUPÇÃO APÓS INSTAURAÇÃO DO PROCESSO ADMINISTRATIVO DISCIPLINAR:}

STF RMS 23436 (DJ: 15/10/1999) Relator: Marco Aurélio

Ementa: [...] A interrupção prevista no $\S 3^{\circ}$ do artigo 142 da Lei $n^{\circ} 8.112$, de 11 de dezembro de 1990, cessa uma vez ultrapassado o período de 140 dias alusivo à conclusão do processo disciplinar e à imposição de pena - artigos 152 e 167 da referida Lei - voltando a ter curso, na integralidade, o prazo prescricional. Precedente: Mandado de Segurança $n^{\circ}$ $22.728-1 / \mathrm{PR},[\ldots]$

\section{ILÍCITOS ADMINISTRATIVOS PENAIS}

\section{Falta de instrução penal:}

STJ ROMS 14420 (DJ: 30/09/2002) Relator: Vicente Leal

Ementa: [...] - Em sede de procedimento administrativo fundado em infração disciplinar que também configura tipo penal, o prazo de prescrição é aquele previsto na lei penal. - A mera presença de indícios de prática de crime sem a devida apuração nem formulação de denúncia, obsta a aplicação do regramento da legislação penal para fins de prescrição, devendo esta ser regulada pela norma administrativa. [...]

Voto: [...] É certo que, nos termos da legislação local (Lei Estadual no 10.098/94, art. 197, $\S 2^{\circ}$ ), quando a infração administrativa também constituir crime deverá ser observada a lei penal para fins de prescrição. Todavia, é de se notar que no caso sub examen em nenhum momento foi oferecida denúncia por qualquer crime cometido pelo recorrente e sequer foi instaurado procedimento tendente a apurá-lo. Ora, se inexiste crime, descaracterizada está a aplicação do referido dispositivo legal, devendo ser aplicado, in casu, o prazo prescricional administrativo e não o penal. [...] A mera existência de indícios da prática de crime, sem a sua efetiva apuração ou oferecimento de denúncia afasta a aplicação da legislação penal para fins de prescrição, devendo esta ser regulada pela legislação administrativa, mais precisamente, a lei estadual no 10.098/94 (Estatuto dos Servidores Públicos Civis do Estado). (grifo nosso)

STJ MS 12090 (DJ: 21/05/2007) Relator: Arnaldo Esteves Lima 
Ementa: [...] 1. Nos casos em que o suposto ilícito praticado pelo servidor público não for objeto de ação penal ou o servidor for absolvido, aplica-se o disposto na legislação administrativa quanto ao prazo prescricional. Precedentes. [...]

Voto: [...] Segundo consta dos autos, foi considerado o prazo prescricional de 12 (doze) anos, ao argumento de que os atos narrados seriam capitulados como crime de falsidade ideológica. A autoridade impetrada, inclusive, em suas informações, afirma que "a impetrante responde a ação penal por suposto delito de falsidade ideológica, ora pendente de julgamento, uma vez que teria inserido dados falsos em documento público, com a finalidade de alterar seu conteúdo e de viabilizar expedição de novo número de CPF para os contribuintes envolvidos" (fl.1.339). No entanto, essa afirmação não encontra respaldo na prova pré-constituída apresentada. A certidão de fl. 1.034, emitida em 20/7/06, prova a inexistência de ação penal em desfavor da impetrante em curso perante a Justiça Federal no Distrito Federal. Nesse ponto, destaca-se a manifestação do Ministério Público Federal, da lavra da Subprocuradora-Geral da República GILDA PEREIRA DE CARVALHO, que asseverou tão-somente a existência de Inquérito Policial em curso na Justiça Federal, mas não de ação penal, razão por que deve ser observado tão-somente o prazo prescricional previsto na Lei 8.112/90, consoante atesta o seguinte excerto (fls. 1.441/1.441v): [...] Por conseguinte, a capitulação dos ilícitos administrativos em exame como crime de falsidade ideológica partiu exclusivamente da Administração, sem respaldo em nenhuma ação penal. Segundo posicionamento adotado no Superior Tribunal de Justiça, nos casos em que o suposto ilícito praticado pelo servidor público não for objeto de ação penal ou o servidor for absolvido, aplica-se o disposto na legislação administrativa quanto ao prazo prescricional. [...] (grifo nosso)

\section{STJ ROMS 14497 (DJ: 15/09/2003) Relator: Gilson Dipp}

Ementa: [...] III - Consoante entendimento do Superior Tribunal de Justiça, a mera presença de indícios de crime, sem a devida apuração criminal, afasta a aplicação da legislação penal para o cômputo da prescrição, devendo ser aplicados os prazos administrativos. Precedentes. [...]

Voto: [...] Por oportuno, cumpre destacar que não prosperam as alegações da D. Autoridade Coatora, no sentido de que seria aplicável o disposto no parágrafo único do art. 261 da Lei $\mathrm{n}^{\circ}$ 10.261/68. Com efeito, em que pesem as infrações administrativas cometidas pelas recorrentes também constituírem crime, não há nos autos elementos que indiquem o eventual oferecimento de denúncia por qualquer crime cometido e tampouco eventual instauração de inquérito para a apuração. Assim, neste hipótese, o prazo prescricional a ser aplicado é o administrativo e não o penal. (grifo nosso)

STJ ROMS 10699 (DJ: 04/02/2002) Relator: Fernando Gonçalves

Ementa: [...] 1 - O prazo de prescrição previsto na lei penal aplica-se às infrações disciplinares capituladas também como crime. Para isto é preciso, no entanto, que o ato de demissão invoque fato definido, em tese, como crime. 2 - Não havendo crime, seja porque não denunciado um dos recorrentes, sendo o outro impronunciado por falta de provas, ausente o parâmetro da lei penal a regular o prazo extintivo da ação estatal, sendo, pois, a sanção de caráter administrativo. Regula, então, a prescrição, neste caso, a legislação relativa ao processo administrativo disciplinar. [...] (grifo nosso) 
STJ EDROMS 13542 (DJ: 24/11/2003) Relator: Gilson Dipp

Ementa: [...] V - Consoante entendimento do Superior Tribunal de Justiça, a mera presença de indícios de crime, sem a devida apuração criminal, afasta a aplicação da legislação penal para o cômputo da prescrição, devendo ser aplicados os prazos administrativos. Precedentes. $\mathrm{Na}$ presente hipótese, não obstante os crimes tenham sido objeto de apuração em ação penal, os impetrantes foram absolvidos, ante a ausência de provas suficientes para a eventual condenação. [...]

Voto: [...] Em que pese uma das infrações administrativas cometidas pelos recorrentes também constituir crime e haver ação penal para a apuração, os servidores foram absolvidos por ausência de provas suficientes para a eventual condenação, nos termos do art. 386, VI do Código de Processo Penal, consoante se verifica às fls. 81/84. Assim, o prazo prescricional da pretensão punitiva da Administração a ser aplicado é o administrativo e não o penal. Não havendo crime, ante a absolvição dos acusados, ausente o parâmetro da lei penal a regular o prazo extintivo da ação estatal. [...] (grifo nosso)

Existência de ação penal proposta.

STJ ROMS 18093 (DJ: 13/12/2004) Relator: Gilson Dipp

Ementa: [...] I - Consoante entendimento deste Superior Tribunal de Justiça, havendo regular apuração criminal, deve ser aplicada a legislação penal para o cômputo da prescrição no processo administrativo. Precedentes. [...] III - Na presente hipótese, constituindo a falta praticada pelo servidor o delito de peculato tipificado no art. 312 do Código Penal, bem como tendo sido o servidor denunciado e estando a ação penal em regular trâmite, aplica-se na instância administrativa o prazo prescricional previsto na instância penal - dezesseis anos, nos moldes do art. 109, II do Código Penal. [...]

Voto: [...] Em dezembro de 2002 o servidor foi demitido do cargo então ocupado por falta grave, sendo certo que a apropriação indevida constituiu também o delito de peculato tipificado no art. 312 do Código Penal. Note-se que o ora recorrente foi denunciado criminalmente, estando a ação penal ainda em regular trâmite. Neste contexto, consoante previsto no parágrafo único do artigo acima transcrito, deve ser adotado na instância administrativa o modelo do prazo prescricional previsto na instância penal. Assim, tendo em vista que a pena cominada em abstrato para o delito de peculato é de 2 (dois) a 12 (doze) anos de reclusão, contrariamente ao alegado pelo recorrente, a prescrição da pretensão punitiva da Administração não ocorrerá em quatro anos, mas sim em dezesseis anos, nos termos do art. 109, II do Código Penal. (grifo nosso)

STJ EDROMS 18551 (DJ: 03/04/2006) Relator: Felix Fischer

Ementa: [...] II- Se aos servidores são imputadas condutas funcionais que também configuram infração penal, o recebimento da denúncia pelo crime de receptação dolosa (art. 180, caput, CP) impõe que o prazo prescricional para a apuração da conduta na 
esfera administrativa seja o da lei penal, conforme previsão da legislação estadual. IIIA eventual suspensão condicional do processo na esfera criminal e o cumprimento do período de prova (art. 89 da Lei $n^{\circ}$ 9.099/95) não afastam a aplicação do prazo prescricional da lei penal para apuração dos fatos na via administrativa.

Voto: [...] Não obstante ter-se imputado aos recorrentes, no inquérito administrativo, várias infrações que, em tese, constituíam diversos ilícitos penais, o certo é que foi instaurada a ação penal com base unicamente no delito de receptação dolosa (art. 180, caput, CP), tendo a proposta de suspensão condicional do processo (sursis processual) sido aceita pelos recorrentes (art. 89, da Lei $n^{0}$ 9.099/95), e já ocorrida a extinção da punibilidade $\left(\$ 5^{\circ}\right.$, art. 89). O que se discute neste mandamus é qual o prazo prescricional se aplica no caso em questão, se o da lei penal ou da lei administrativa. [...] Pelo que se vê, o estatuto em questão, e de resto a grande maioria dos estatutos de servidores públicos, consagra a regra segundo a qual se a conduta do servidor configurar infração administrativa e penal ao mesmo tempo, o prazo prescricional para apuração na via administrativa será a da lei penal. O que se discute é se a suspensão condicional do processo (art. 89 da Lei n $^{\circ}$ 9.099/95) na esfera penal tem o condão de afastar a regra da contagem da prescrição pela lei penal, uma vez que aqui não há condenação dos acusados. A suspensão condicional do processo, ou sursis processual, é medida de política criminal, fundada no Direito Penal Mínimo, que visa a evitar submeter o acusado de crimes não considerados graves ao "flagelo" de um processo penal que, muitas vezes, só o fato da sua instauração, constitui castigo para o acusado. [...] Não é correta, pois, a interpretação de que a proposta da suspensão condicional do processo configura renúncia à apuração da infração penal. [...] Nesse contexto, não se configura a suspensão processual falta de apuração da infração penal, mas apenas uma medida de economia processual que tem como base uma forte possibilidade de condenação futura do acusado, cuja pena o Estado, por razões de política criminal, prefere deixar suspensa, submetendo o condenado a um período de prova, findo o qual resta extinta a punibilidade, não é correto, só por este fato, afastar o prazo da lei penal para regular a prescrição na esfera administrativa. Portanto, apesar de os recorrentes terem se beneficiado com a suspensão processual, tal fato, porque não caracteriza a falta de apuração criminal das suas condutas, não afasta a contagem da prescrição pela lei penal. [...] Assim, como não houve absolvição criminal, o prazo prescricional continua a ser regulado pela pena abstratamente prevista na lei penal, independentemente se houve ou não a extinção da punibilidade pelo cumprimento das condições impostas durante o período de prova $\left(\S 5^{\circ}\right.$, art. 89 , Lei $\mathrm{n}^{\circ}$ 9.099/95). (grifo nosso)

\section{STJ ROMS 15363 (DJ: 02/08/2004) Relator: Jorge Scartezzini}

Voto: [...] Condenado pela prática do crime de concussão à pena de 2 (dois) anos de reclusão (fls. 262/296), apelou o recorrente de sua sentença, tendo esta transitado em julgado para a acusação no dia 23.03 .98 (fls. 190). A Segunda Câmara Criminal da Corte $a$ quo, nos autos da Apelação Criminal $\mathrm{n}^{\circ}$ 261.042.3/2-03, com base na pena imposta pela sentença condenatória, acolheu Embargos de Declaração para julgar extinta a punibilidade [penal] do réu pela prescrição retroativa (fls. 536). [...] Ressalte-se que a prescrição na esfera penal, depois da sentença condenatória com trânsito em julgado para a acusação, regula-se pela pena aplicada, de acordo com o art. $110, \S 1^{\circ}$, do Código Penal. $\mathrm{Na}$ espécie, o citado trânsito em julgado configurou-se antes do ato demissionário (datado de 25.04.01 e publicado em 26.04.01) e antes também da impetração do writ, autuado em 08.08.01. Logo, o prazo da prescrição na esfera administrativa se computa da pena in 
concreto, nos termos do art. $110 \mathrm{c} / \mathrm{c}$ o art. 109, ambos do Código Penal, sendo, in casu, de 04 (quatro) anos. [...] (grifo nosso)

Forma do cômputo do prazo da prescrição penal no processo administrativo disciplinar:

STJ MS 10078 (DJ: 26/09/2005) Relator: Arnaldo Esteves Lima

Ementa: [...] 2. Havendo o cometimento, por servidor público federal, de infração disciplinar capitulada também como crime, aplicam-se os prazos de prescrição da lei penal e as interrupções desse prazo da Lei 8.112/90, quer dizer, os prazos são os da lei penal, mas as interrupções, do Regime Jurídico, porque nele expressamente previstas. Precedentes. 3. A Administração teve ciência, em 22/5/1995, da infração disciplinar praticada pelo impetrante, quando se iniciou a contagem do prazo prescricional [...]

Voto: [...] No caso em exame, o fato praticado pelo impetrante [...] foi cometido em 21/5/1995. No dia seguinte, em 22/5/1995, a Administração tomou ciência do ilícito [...], porquanto colheu depoimento da vítima, data a partir da qual começou a correr o prazo prescricional, de acordo com o art. 142, $\S 1^{\text {e}}$, da Lei 8.112/90. (grifo nosso)

STJ MS 9772 (DJ: 26/10/2005) Relator: Laurita Vaz

Ementa: [...] 1. Nos termos do art. $142, \S 2^{\circ}$, da Lei n. ${ }^{\circ} 8.112 / 90$, aplicam-se às infrações disciplinares capituladas também como crime, os prazos prescricionais previstos na lei penal. Precedentes. 2. O prazo para a Administração aplicar a pena de demissão ao servidor faltoso é de 5 (cinco) anos, a teor do que dispõe o art. 142, inciso I, da Lei n. ${ }^{\circ}$ 8.112/90. Entretanto, havendo regular apuração criminal, o prazo de prescrição no processo administrativo disciplinar será regulado pela legislação penal, que, in casu, consoante o art. 316 c.c. o art. 109, inciso III, do Código Penal, é de 12 (doze) anos. 3. Na hipótese, a contagem do prazo prescricional foi interrompida com a instauração de novo PAD em 04/09/2003, voltando a correr por inteiro em 21/01/2004, após o transcurso de 140 (cento e quarenta) dias [...]

Voto: [...] Nesse contexto, [...], o prazo prescricional da pretensão punitiva da Administração é de 12 (doze) anos. Na espécie, informam os autos que o fato se tornou conhecido pela Administração em 20/11/1998, data que constitui o termo a quo para a contagem do lapso prescricional, nos termos do $\S 1^{\circ}$ do art. 142 anteriormente transcrito. No entanto, após a anulação de dois processos disciplinares que continham vícios insanáveis, a contagem da prescrição foi interrompida com a instauração de novo PAD em 04/09/2003 (fl. 44), voltando o prazo a correr por inteiro em 21/01/2004, após o transcurso de 140 (cento e quarenta) dias [...], constata-se, a toda evidência, a nãoocorrência da prescrição da pretensão punitiva da Administração Federal, a qual somente ocorreria em 21/01/2016. (grifo nosso)

STJ EDROMS 18551 (DJ: 03/04/2006) Relator: Felix Fischer 
Ementa: [...] IV- Na espécie, o prazo prescricional da lei penal é de 08 anos, sendo que o processo administrativo disciplinar foi instaurado seis anos depois do conhecimento da autoridade, dentro, portanto, do prazo legal. (grifo nosso)

STJ MS 9568 (DJ: 02/08/2006) Relator: Arnaldo Esteves Lima

Voto: [...] Da leitura dos referidos dispositivos legais, conclui-se que, havendo o cometimento, por servidor público federal, de infração disciplinar capitulada também como crime, observam-se os prazos de prescrição da lei penal. Deduz-se, também, que a abertura de sindicância ou a instauração de processo disciplinar interrompe a prescrição. [...] De outra parte, não obstante a aplicação dos prazos de prescrição da lei penal, as hipóteses de interrupção da Lei 8.112/90 continuam a ser observadas porque ali se encontram previstas expressamente. (grifo nosso)

STJ ROMS 21930 (DJ: 23/10/2006) Relator: Arnaldo Esteves Lima

Ementa: [...] 2. Havendo o cometimento, por servidor da Polícia Civil do Estado de São Paulo, de infração disciplinar capitulada também como crime, aplicam-se os prazos de prescrição da lei penal e as interrupções desse prazo da Lei Complementar Estadual 207/79, ou seja, os prazos são os da lei penal, mas as interrupções do Regime Jurídico, porque nele expressamente previstas. 3. [...] In casu, a Administração teve conhecimento dos fatos imputados ao recorrente em 19/11/1998; em 30/6/2000 foi instaurado processo disciplinar, interrompendo o prazo prescricional; [...] (grifo nosso)

STJ ROMS 13395 (DJ: 02/08/2004) Relator: Hamilton Carvalhido

Voto: [...] A lei 8.112/91, com efeito, que rege os servidores públicos federais, estabelece no parágrafo $2^{\circ}$ do seu artigo 142 que às infrações disciplinares também tipificadas como crime aplicam-se os prazos prescricionais previstos na lei penal, afastando, por conseguinte, os prazos prescricionais das ações disciplinares, previstos no incisos I a III, do mesmo artigo. [...] Tal disciplina, todavia, se refere exclusivamente, a nosso ver, ao prazo, não às causas interruptivas da prescrição, diante dos peremptórios termos do artigo 142 da Lei 8.112/90. (grifo nosso)

STJ ROMS 15585 (DJ: 03/04/2006) Relator: Arnaldo Esteves Lima

Ementa: [...] 2. Havendo o cometimento, por servidor da Polícia Civil do Estado do Rio Grande do Sul, de infração disciplinar capitulada também como crime, aplicam-se os prazos de prescrição da lei penal e as interrupções e suspensões desse prazo da Lei Estadual 7.366/80, quer dizer, os prazos são os da lei penal, mas as interrupções, do Regime Jurídico, porque nele expressamente previstas. [...] (grifo nosso)

STJ ROMS 18319 (DJ: 30/10/2006) Relator: Laurita Vaz

Ementa: [...] 1. Uma vez condenado o Recorrente na esfera criminal, quanto ao crime de roubo tentado, à pena de 2 (dois) anos de reclusão, resta evidenciada a prescrição, tendo em conta que desde a data do fato 26/03/1996, até a instauração do processo administrativo, ocorrida em 27/09/2000, já havia decorrido prazo superior a 4 (quatro) anos, necessário à configuração da prescrição. (grifo nosso) 
STJ ROMS 17882 (DJ: 25/09/2006) Relator: Laurita Vaz

EMENTA: [...] 1. Com efeito, uma vez condenado o Recorrente na esfera criminal, quanto ao crime de estelionato, à pena de 1 (um) ano de reclusão - tendo havido recurso apenas da defesa, resta evidenciada a prescrição, tendo em conta que, desde a data do fato ou mesmo do conhecimento do fato, até a instauração do processo administrativo, ocorrida em 03/04/2000, já decorrera prazo superior a 4 (quatro) anos, necessário à configuração da prescrição. [...] (grifo nosso)

Aplicação do prazo prescricional penal in concreto:

STJ ROMS 13395 (DJ: 02/08/2004) Relator: Hamilton Carvalhido

Ementa: [...] 2. Ao se adotar na instância administrativa o modelo do prazo prescricional vigente na instância penal, deve-se aplicar os prazos prescricionais ao processo administrativo disciplinar nos mesmos moldes que aplicados no processo criminal, vale dizer, prescreve o poder disciplinar contra o servidor com base na pena cominada em abstrato, nos prazos do artigo 109 do Código Penal, enquanto não houver sentença penal condenatória com trânsito em julgado para acusação, e, após o referido trânsito ou improvimento do recurso da acusação, com base na pena aplicada em concreto (artigo 110, parágrafo $1^{\circ}$, combinado com o artigo 109 do Código Penal)

STF MS 23242 (DJ 17/05/2002) Relator: Carlos Velloso

Ementa: [...] III. - Na hipótese de a infração disciplinar constituir também crime, os prazos de prescrição previstos na lei penal têm aplicação: Lei 8.112/90, art. 142, § $2^{\circ}$. Inocorrência de prescrição, no caso. [...]

Voto: [...] Também não procede a alegação no sentido de ter ocorrido, no caso, prescrição, conforme magistralmente esclarecido no parecer do Dr. Flávio Giron, que transcrevo: "[...] Ocorre que no caso ora em exame incidente primeiramente será o artigo $110, \S 1^{\circ}$, do Código Penal, visto que houve sentença penal condenatória com trânsito em julgado para a acusação, [...]. Assim, o prazo prescricional terá que ser regulado pela pena concretamente aplicada [...]. Assim, o prazo prescricional será de oito anos, já que a pena fixada pela sentença de 2 (dois) anos e 8 (oito) meses é que regulou concretamente a prescrição, [...]" (grifo nosso)

STJ ROMS 15363 (DJ: 02/08/2004) Relator: Jorge Scartezzini

Ementa: [...] 1 - A falta disciplinar tipificada como infração penal prescreve no mesmo prazo desta, conforme o art. 80, IV, da Lei Complementar Estadual n ${ }^{\circ}$ 207/79. Ressalte-se que a prescrição na esfera penal, depois da sentença condenatória com trânsito em julgado para a acusação, regula-se pela pena aplicada (art. 110, § $1^{\circ}$, do Código Penal). [...] Logo, o prazo da prescrição na esfera administrativa se computa da pena in concreto, nos termos do art. 110 c/c o art. 109, ambos do Código Penal, sendo, na hipótese dos autos, de 4 (quatro) anos. [...] (grifo nosso) 
Aplicação de prazo penal in concreto quando este for menor que o do ilícito administrativo puro:

STJ ROMS 15363 (DJ: 02/08/2004) Relator: Jorge Scartezzini

Ementa: [...] Logo, o prazo da prescrição na esfera administrativa se computa da pena in concreto, [...], sendo, na hipótese dos autos, de 4 (quatro) anos. (grifo nosso)

STJ ROMS 17882 (DJ: 25/09/2006) Relator: Laurita Vaz

Ementa: [...] 1. Com efeito, uma vez condenado o Recorrente na esfera criminal, quanto ao crime de estelionato, à pena de 1 (um) ano de reclusão - tendo havido recurso apenas da defesa, resta evidenciada a prescrição, tendo em conta que, desde a data do fato ou mesmo do conhecimento do fato, até a instauração do processo administrativo, ocorrida em 03/04/2000, já decorrera prazo superior a 4 (quatro) anos, necessário à configuração da prescrição. [...] (grifo nosso)

STJ ROMS 18319 (DJ: 30/10/2006) Relator: Laurita Vaz

Ementa: [...] 1. Uma vez condenado o Recorrente na esfera criminal, quanto ao crime de roubo tentado, à pena de 2 (dois) anos de reclusão, resta evidenciada a prescrição, tendo em conta que desde a data do fato 26/03/1996, até a instauração do processo administrativo, ocorrida em 27/09/2000, já havia decorrido prazo superior a 4 (quatro) anos, necessário à configuração da prescrição. (grifo nosso)

STJ MS 8560 (DJ: 01/07/2004) Relator para Acórdão: Laurita Vaz

Ementa: [...] 1. Nos termos do art. 142, § 2. ${ }^{\circ}$, da Lei n. ${ }^{\circ} 8.112 / 90$, o prazo prescricional previsto na lei penal aplica-se à infração disciplinar também capitulada como crime. 2 . Tendo o TRF da $1 .^{a}$ Região, em sede de apelação criminal, reduzido para o mínimo legal a pena imposta ao ora Impetrante pela prática do delito de concussão, o prazo prescricional deve ser regulado pelo disposto no art. 109, inciso V, do Código Penal (04 anos). (grifo nosso)

Prescrição do ilícito de "abandono de cargo". (cuja prescrição penal é menor que se fosse um ilícito administrativo puro).

STJ MS 12884 (DJ: 22/04/2008) Relator: Maria Thereza de Assis Moura

Ementa: [...] 2. Transcorrido mais de 5 anos entre a data em que se tomou conhecimento da ausência da impetrante ao serviço público ( $31^{\circ}$ dia após $\left.13 / 07 / 98\right)$ e a data de instauração do processo administrativo (07/02/2006), primeiro marco prescricional, é de se entender prescrita a pretensão estatal de aplicar a pena de demissão à impetrante. 3 . A tese de que o abandono do cargo se renova a cada 30 dias, haja vista a sua natureza de infração permanente, é descabida, porquanto além de não encontrar respaldo na doutrina e na jurisprudência, a lei é clara ao estipular a data inicial em que se deve iniciar o 
cômputo do prazo prescricional, daí porque o intento administrativo é tão somente estabelecer hipótese de prorrogação do prazo prescricional não prevista em lei. 4. A referida tese denota o intento do ente estatal de criar uma nova hipótese infundada de renovação de prazo prescricional, provavelmente para corrigir o equívoco relativo ao demasiado tempo que se levou para instaurar o processo administrativo, deixando este ser atingido pela prescrição. 5. Mandado de segurança concedido. (grifo nosso)

STJ MS 7318 (DJ: 07/10/2002) Relator: Gilson Dipp

Voto: [...] Ainda sobre a incidência da prescrição, verifica-se que a ausência injustificada da servidora teve início em 20 de maio de 1994. Completados os 30 (trinta) dias faltantes, conforme prevê o art. 138 da Lei 8.112/90, deu-se início à contagem para aferição da prescrição punitiva no $31^{\circ}$ dia $(21 / 06 / 94)$. [...]

STJ MS 7706 (DJ: 03/05/2004) Relator: Paulo Medina

Voto: [...] Às f. 665, verifico haver processo crime contra o impetrante. Não obstante, inexiste referência à denúncia nem há elementos suficientes para apurar se o servidor teria praticado o crime do caput do art. 323, ou de seu parágrafo único, que implicam em prazos prescricionais diversos. Os elementos da instância criminal são essenciais para que se conclua sobre o prazo prescricional: o da lei administrativa, de cinco anos; ou os possíveis prazos da lei penal, calculados em função da pena máxima cominada em abstrato ou pela pena concreta a que o réu é condenado. Dessa forma, os documentos dos autos não bastam para se concluir pela perda da ação por decurso de prazo. Entretanto, a autoridade administrativa reconhece ter havido a prescrição, no bojo do ato impugnado. [...] (grifo nosso)

STJ ROMS 13134 (DJ: 01/07/2004) Relator: Paulo Medina

Ementa: [...] O prazo de prescrição aplicável na espécie é a da lei administrativa. Para que incida o prazo da lei penal faz-se necessário não só o ato disciplinar como também a devida apuração criminal. Precedentes. [...]

Voto: [...] Não subsiste a tese da necessária aplicação do prazo de prescrição da lei penal, ao mero argumento de que o fato imputado à impetrante também configura crime. Assentada jurisprudência desta Corte entende que a hipótese apenas se configura se há a devida apuração dos fatos em processo crime. [...] Na hipótese vertente, não se verifica a apuração criminal dos fatos, havendo, apenas, indícios da prática de crime. Correto, pois, o reconhecimento do prazo de prescrição de 5 (cinco) anos, previsto pela lei administrativa, que leva à inarredável conclusão de que a pena administrativa não estava prescrita. Registre-se, ainda, que, segundo o juízo da administração, houve apenas a falta administrativa, não o crime e, em mandado de segurança, é vedado ao Poder Judiciário substituir o administrador na apuração do mérito de necessidade de representação ao Ministério Público por eventual prática de ilícito criminal. [...] (grifo nosso)

STJ MS 12884 (DJ: 22/04/2008) Relator: Maria Thereza de Assis Moura

Ementa: [...] 1. Consolidou-se nesta Corte o entendimento de que, no caso de cometimento por servidor público de infração disciplinar também tipificada como crime, somente se 
aplica o prazo prescricional previsto na legislação penal quando os fatos também forem apurados na esfera criminal. Como na espécie não houve tal apuração, é de se aplicar o prazo prescricional de 5 anos, de acordo com o art. 142, I, da Lei ${ }^{\circ} 8.112 / 90$. [...] (grifo nosso)

STJ MS 7239 (DJ: 13/12/2004) Relator: Laurita Vaz

Voto: [...] Nos moldes do art. 142, § $2^{\circ}$, da Lei 8.112/90, os prazos prescricionais da pretensão punitiva previstos na lei penal, aplicam-se às infrações disciplinares capituladas também como crime. A jurisprudência desta Corte relativa ao tema, é firme no sentido de que "a mera presença de indícios de prática de crime sem a devida apuração nem formulação de denúncia, obsta a aplicação do regramento da legislação penal para fins de prescrição, devendo esta ser regulada pela norma administrativa", especificamente, o caput do aludido art. 142 da norma estatutária (Cf.: RMS 14.420/RS, rel. Min. VICENTE LEAL, DJ de 30/09/2002). Na hipótese em concreto, os documentos dos autos não são suficientes para se concluir pela perda da ação por decurso do prazo. Todavia, a despeito de haver ocorrido ou não a prescrição, a Autoridade impetrada reconhece, expressamente, em diversas oportunidades, que a Administração se encontrava impedida de aplicar a pena de demissão em virtude da extinção da punibilidade estatal pela prescrição da pretensão punitiva - cujo lapso temporal era o de 02 (dois) anos -, tendo em vista o ilícito penal. [...] (grifo nosso)

\section{STJ MS 7318 (DJ: 07/10/2002) Relator: Gilson Dipp}

Voto: [...] Da concatenação dos dispositivos legais transcritos [Lei n ${ }^{\circ}$ 8.112/90 artigos 138, 132, II e 142, § $2^{\circ}$ e Código Penal artigos 323 e 109, VI], depreende-se que a sanção administrativa de abandono de cargo é igualmente punível no âmbito penal. Desta forma, a teor da própria Lei 8.112/90, o seu prazo prescricional segue o definido no art. 109, VI do CPB. No caso específico, o prazo é de 2 (dois) anos. Aliás, quanto a este particular, não há controvérsias, pois tanto a Administração quanto a impetrante comungam da mesma ratio. Ainda sobre a incidência da prescrição, verifica-se que a ausência injustificada da servidora teve início em 20 de maio de 1994. Completados os 30 (trinta) dias faltantes, conforme prevê o art. 138 da Lei 8.112/90, deu-se início à contagem para aferição da prescrição punitiva no $31^{\circ}$ dia (21/06/94). Desta forma, o prazo capital ocorreu aos 21 de junho de 1996, sendo certo que a Universidade Federal do Ceará somente instaurou o processo administrativo disciplinar em 09 de setembro de 1997, ou seja, a punibilidade já se encontrava prescrita. A esse respeito, também não há divergências. (grifo nosso)

STJ MS 8975 (DJ: 08/02/2006) Relator: Paulo Gallotti

Ementa: [...] 1. A prescrição da pretensão punitiva da Administração, nos casos de infrações disciplinares capituladas também como crime, é regulada pelo art. 109 do Código Penal, conforme determina o $\S 2^{\circ}$ do art. 142, da Lei $\mathrm{n}^{\circ} 8.112 / 90$.

Voto: [...] Como se vê dos dispositivos legais transcritos, a sanção administrativa de abandono de cargo é também figura típica punível no âmbito penal e, como tal, a prescrição é regulada de acordo com o art. 109 do Código Penal, conforme preceitua o $\$ 2^{\circ}$ do art. 142 da Lei $n^{\circ} 8.112 / 90$. Ora, é incontroverso que o abandono do cargo público por parte do impetrante foi conhecido em abril de 1997 e o procedimento 
administrativo só foi instaurado em outubro de 2001. Assim, sendo de dois anos o prazo para o exercício da pretensão punitiva de acordo com o contido no art. 109, VI, do Código Penal, em obediência ao $§ 2^{\circ}$ do art. 142 da Lei $n^{\circ} 8.112 / 90$, inegavelmente, perdeu a Administração a oportunidade de demitir o servidor por não ter dado curso ao processo quando lhe competia. (grifo nosso)

Exoneração ex officio no abandono de cargo:

STF MS 20111 (DJ: 23/03/1979) Relator: Xavier de Albuquerque

Ementa: Exoneração "ex officio". É aplicável a funcionário que, havendo abandonado o cargo, nem pode ser demitido, por se haver consumado a prescrição, nem solicita exoneração. Interpretação do art. 75 da Lei n. 1711, de 28.10.52. Mandado de Segurança denegado.

A jurisprudência do STJ, entretanto, é frontalmente contrária, em todos os precedentes, sejam antigos ou recentes:

STJ MS 7113 (DJ: 04/11/2002) Relator: Felix Fischer

Ementa: [...] II - A Lei no 8.112/90 prevê expressamente, no parágrafo único de seu art. 34, as duas hipóteses de cabimento da figura de exoneração ex officio. A primeira se dá "quando não satisfeitas as condições do estágio probatório", e, a segunda, "quando, tomado posse, o servidor não entrar em exercício no prazo estabelecido". III - No caso de infração disciplinar de abandono de cargo, punível com pena de demissão, a teor do art. 132, inciso II, da Lei $n^{0} 8.112 / 90$, não pode a Administração Pública, ao seu próprio alvedrio, exonerar ex officio servidora pública estável, ocupante de cargo efetivo do Instituto Nacional do Seguro Social - INSS, quando já reconhecida a prescrição da pretensão punitiva pela Administração, sob pena de violação ao princípio da legalidade. IV - Imperioso se torna o reconhecimento da nulidade da Portaria $n^{\circ}$ 576/2000, que exonerou de ofício a servidora do cargo de Agente de Portaria dos quadros do INSS, com a consequente reintegração da mesma no cargo de origem. [...] (grifo nosso)

STJ MS 7239 (DJ: 13/12/2004) Relator: Laurita Vaz

Ementa: [...] 3. A exoneração "ex officio", de que trata o art. 34 da Lei 8.112/90, não se destina a resolver os casos em que não se pode aplicar a demissão, em virtude de se ter reconhecida pela Administração a prescrição da pretensão punitiva estatal. Desse modo, eivado de nulidade o ato exoneratório, por evidente ofensa ao princípio da legalidade. Precedentes. [...] (grifo nosso)

STJ MS 7318 (DJ: 07/10/2002) Relator: Gilson Dipp

Ementa: [...] I- A exoneração "ex officio" (art. 34 da Lei 8.112/90), não se destina a resolver os casos em que não se pode aplicar a demissão. II- Cometida a infração disciplinar, o direito abstrato de punir do ente administrativo convola-se em concreto. 
Todavia, o jus puniendi só pode ser exercido dentro do prazo prescrito em lei. Na hipótese dos autos, foi apurado que a servidora abandonou o Cargo de Professora Universitária na Universidade Federal do Ceará. Todavia, a Administração somente instaurou o processo administrativo disciplinar quando já havia expirado o prazo prescricional. Desta forma, inviável a declaração de sua exoneração "ex officio", especialmente por se tratar de servidora efetiva e estável, não incidindo nenhuma das hipóteses do art. 34 da Lei 8.112/90. III- O princípio da legalidade preconiza a completa submissão da Administração às leis. In casu, o ato atacado denotou postura ilegal por parte da própria Administração, já que a solução encontrada objetivou, apenas, minorar os efeitos da sua própria inércia ao não exercer um poder-dever. Neste aspecto, a adoção da tese defendida implica em verdadeira violação ao ordenamento jurídico. IV- Reconhecida a prescrição, impõe-se declarar a extinção da punibilidade, tornando-se nula a Portaria exoneratória, a fim que a servidora seja reintegrada ao serviço público. V- Segurança concedida. (grifo nosso)

STJ EDMS 7318 (DJ: 16/12/2002) Relator: Gilson Dipp

Ementa: [...] II - A exoneração "ex officio" (art. 34 da Lei 8.112/90), não se destina a resolver os casos em que não se pode aplicar a demissão. III - Cometida a infração disciplinar, o direito abstrato de punir do ente administrativo convola-se em concreto. Todavia, o jus puniendi só pode ser exercido dentro do prazo prescrito em lei. Na hipótese dos autos, foi apurado que a servidora abandonou o Cargo de Professora Universitária na Universidade Federal do Ceará. Todavia, a Administração somente instaurou o processo administrativo disciplinar quando já havia expirado o prazo prescricional. Desta forma, inviável a declaração de sua exoneração "ex officio", especialmente por se tratar de servidora efetiva e estável, não incidindo nenhuma das hipóteses do art. 34 da Lei 8.112/90. IV- O princípio da legalidade preconiza a completa submissão da Administração às leis. In casu, o ato atacado denotou postura ilegal por parte da própria Administração, já que a solução encontrada objetivou, apenas, minorar os efeitos da sua própria inércia ao não exercer um poder-dever. Neste aspecto, a adoção da tese defendida implica em verdadeira violação ao ordenamento jurídico. V-Reconhecida a prescrição, impõe-se declarar a extinção da punibilidade, tornando-se nula a Portaria exoneratória, a fim que a servidora seja reintegrada ao serviço público. VI - Embargos de declaração rejeitados. (grifo nosso)

STJ MS 7706 (DJ: 03/05/2004) Relator: Paulo Medina

Ementa: [...] A exoneração de ofício é nula se o ato reconhece a prescrição e a impossibilidade de demitir o servidor. A exoneração não se confunde com penalidade e $o$ ato de exoneração que visa substituir pena de demissão sofre de desvio de finalidade. Segurança concedida em parte. (grifo nosso)

STJ MS 8975 (DJ: 08/02/2006) Relator: Paulo Gallotti

Ementa: [...] 2. "I - A exoneração ex officio (art. 34 da Lei no 8.112/90), não se destina a resolver os casos em que não se pode aplicar a demissão. II - Cometida a infração disciplinar, o direito abstrato de punir do ente administrativo convola-se em concreto. Todavia, o jus puniendi só pode ser exercido dentro do prazo prescrito em lei. III - O princípio da legalidade preconiza a completa submissão da Administração às leis. In casu, o ato atacado denotou postura ilegal por parte da própria Administração, já que a solução 
encontrada objetivou, apenas, minorar os efeitos da sua própria inércia ao não exercer um poder-dever. Neste aspecto, a adoção da tese defendida implica em verdadeira violação ao ordenamento jurídico. IV - Reconhecida a prescrição, impõe-se declarar a extinção da punibilidade, tornando-se nula a Portaria exoneratória, a fim de que a servidora seja reintegrada ao serviço público." (MS N $\mathrm{N}^{\circ}$ 7.318/DF, Relator o Ministro GILSON DIPP, DJU de 7/10/2002) 3.Segurança concedida. (grifo nosso)

STJ MS 12325 (DJ: 06/08/2007) Relator: Paulo Gallotti

Ementa: [...]1. Versa a controvérsia sobre a possibilidade de punir servidor estável com a exoneração de ofício, em caso de abandono da função, quando a própria Administração reconhece que o prazo prescricional já expirou. 2. A conduta da autoridade apontada como coatora, exonerando ex officio o impetrante, acabou por violar o princípio da legalidade, uma vez que inocorrentes na espécie as hipóteses do art. 34, parágrafo único, I e II, da Lei $n^{\circ}$ 8.112/90, que trata da exoneração de cargo efetivo a pedido do servidor ou de ofício pela Administração. 3. Segurança concedida. (grifo nosso)

Suspensão automática do prazo prescricional por propositura de ação judicial:

STJ MS 7095 (DJ: 14/04/2003) Relator: Gilson Dipp

Ementa: [...] I- Não procede a tese calcada na incidência da prescrição punitiva da Administração, quando a demora na conclusão do processo decorre, exclusivamente, de atos procrastinatórios intentados pelo próprio servidor. Desta forma, não é correto imputar ao ente público ônus a que não deu causa. [...]

Voto: [...] Quanto aos pontos arguidos na exordial, não procede a alegação de prescrição por inércia da Administração, pois a demora na conclusão do processo não ocorreu por culpa da Administração, mas, ao contrário, pela suspensão do seu andamento, em decorrência dos vários pedidos de sobrestamento formulados pela própria impetrante, especialmente nas ações judiciais por ela intentadas, com vistas a procrastinar o compêndio administrativo. Dentre as ações mencionadas, sobressaem as seguintes: [...], sendo certo que o trânsito em julgado do último ocorreu aos 31 de outubro de 1997. [...] (grifo nosso)

STJ MS 9568 (DJ: 02/08/2006) Relator: Arnaldo Esteves Lima

Ementa: [...] 4. Diante do fato de que a Administração restou impedida de aplicar a pena de demissão ao impetrante até o trânsito em julgado do acórdão em referência, que reformou a sentença concessiva da segurança, não há falar em ocorrência da prescrição da pretensão punitiva do Estado e de aplicação da "teoria do fato consumado" para justificar a reintegração do servidor no cargo. 5. Segurança denegada.

Voto: [...] Todavia, na hipótese, a contagem do prazo prescricional não se dará a partir da instauração do processo administrativo, uma vez que a Administração se viu impedida de aplicar a pena de demissão ao impetrante em razão de decisão judicial proferida 
em primeira instância nos autos do já citado Mandado de Segurança n 89.0003887-7, impedimento este que perdurou até o trânsito em julgado do acórdão que julgou a Apelação 92.01.25482-2-DF, que denegou a segurança, ocorrido em 25/2/2003 (fl. 213). (grifo nosso)

STJ ROMS 10265 (DJ: 18/11/2002) Relator: Vicente Leal

Ementa: [...] - Não ocorre a prescrição da ação disciplinar se o prazo foi interrompido em razão da instauração de processo administrativo que esteve paralisado, em razão de concessão de liminar em mandado de segurança, não sendo atingido o prazo legal de 5 (cinco) anos. [...] (grifo nosso)

Prescrição quando anulado o processo administrativo disciplinar:

STF MS 22728 (DJ: 13/11/1998) Relator: Moreira Alves

Voto: [...], o que é certo é que, declarado nulo o processo primitivo, desaparece a causa de interrupção da prescrição decorrente de sua instauração, e a prescrição volta a aferir-se do período entre a data em que o fato se tornou conhecido e a instauração do novo processo. Ora, no caso, entre essas duas datas não decorreram os cinco anos para a ocorrência da prescrição. (grifo nosso)

STJ MS 7081 (DJ: 04/06/2001) Relator: Felix Fischer

Ementa: [...] I - Inocorrência de prescrição, tendo em vista que, anulado o primeiro processo disciplinar, a causa interruptiva da prescrição surgida com a sua instauração desaparece, de modo que o prazo prescricional será contado entre a data em que o fato se tornou conhecido e a instauração do novo processo. Precedentes do c. STF. [...] (grifo nosso)

STJ MS 8192 (DJ: 26/06/2006) Relator: Arnaldo Esteves Lima

Ementa: [...] 6. Havendo anulação da sindicância, porque sua declaração determina a exclusão do mundo jurídico do ato viciado, o prazo prescricional da pretensão punitiva volta a ser contado da ciência, pela Administração, da prática do suposto ilícito administrativo. Precedente. (grifo nosso)

STJ MS 8558 (DJ: 16/12/2002) Relator: Vicente Leal

Ementa: [...] - A declaração de nulidade do processo administrativo implica na desconstituição de todos os seus atos, inclusive o de instauração da Comissão Disciplinar, o que resulta na inexistência do ato interruptivo da prescrição, que deve ser contada, consequentemente, desde o conhecimento do fato lesivo até a instauração do segundo processo disciplinar. $[\ldots]$ 
Voto: [...] Todavia, em 19 de junho de 1998, a autoridade competente para o julgamento administrativo proferiu decisão anulatória do processo disciplinar, após detectar a presença de vícios insanáveis no mesmo (fls. 112/113). [...] Com efeito, o reconhecimento da nulidade do primeiro processo administrativo implica na desconstituição de todos os seus atos, inclusive o de instauração da Comissão Disciplinar, o que resulta na inexistência do ato interruptivo da prescrição, que deve ser contada, consequentemente, desde o conhecimento do fato lesivo até a instauração do segundo processo administrativo. (grifo nosso)

STJ MS 9772 (DJ: 26/10/2005) Relator: Laurita Vaz

Voto: [...] Na espécie, informam os autos que o fato se tornou conhecido pela Administração em 20/11/1998 (fls. 14; 63), data que constitui o termo a quo para a contagem do lapso prescricional, nos termos do $\S 1^{\circ}$ do art. 142 anteriormente transcrito. No entanto, após a anulação de dois processos disciplinares que continham vícios insanáveis, a contagem da prescrição foi interrompida com a instauração de novo PAD em 04/09/2003 (fl. 44), [...] (grifo nosso)

STJ RESP 456829 (DJ: 09/12/2002) Relator: Vicente Leal

Ementa: [...] - O reconhecimento da nulidade do processo administrativo implica na desconstituição de todos os seus atos, inclusive o de instauração da Comissão Disciplinar, o que resulta na inexistência do ato interruptivo da prescrição, que deve ser contada, consequentemente, desde o conhecimento do fato lesivo até a instauração do segundo processo disciplinar. (grifo nosso)

STJ RESP 643462 (DJ: 21/11/2005) Relator: José Arnaldo da Fonseca

Ementa: [...] Ocorrência da prescrição administrativa da pena de advertência, tendo em conta a anulação do primeiro procedimento (sindicância). (grifo nosso)

STJ ROMS 13386 (DJ: 01/07/2002) Relator: José Arnaldo da Fonseca

Ementa: [...] O primeiro procedimento administrativo respondido pelo impetrante restou anulado pelo Judiciário, não havendo falar-se em prescrição punitiva da Administração quando instaurou o segundo procedimento. [...] (grifo nosso) 


\section{QUARTA PARTE - CONCLUSÕES.}

1 - A passagem do tempo é fenômeno dos mais relevantes do ponto de vista jurídico, de há muito a dialética desta relação é estudada. $\mathrm{O}$ tempo dá ao Direito uma sedimentação que permite segurança para pavimentar o caminho ao futuro. De outra banda o Direito permite que o tempo imemorial à mente permaneça por meio de documentos e outras formas, ao passo que, por vezes exige o esquecimento justamente para que permaneça e prevaleça o Direito. Neste ponto se situa a prescrição extintiva.

2 - A prescrição que inicialmente foi instituto pelo qual apenas eram adquiridos direitos, usucapio, foi ao longo dos séculos se modificando de forma que hoje, no mais das vezes é invocada para a extinção deles, pela prescrição podese excluir a possibilidade de apenar alguém, ainda que haja responsabilidade demonstrada, porém tal afirmação não deve ser vista como fator de impunidade, mas sim enquanto útil para a sociedade em suas relações jurídicas.

3 - A responsabilidade dos agentes públicos é atingida pela prescrição; tal responsabilidade pode se dar em três esferas distintas a civil, a penal e a administrativa. Em se tratando de pessoas que possuem vínculo com a Administração Pública, em regra o mais forte traço é o da responsabilidade administrativa, no entanto uma conduta poderá a um só tempo caracterizar mais de uma e até mesmo as três espécies de responsabilidade. É que devido à independência das instâncias e aos bens jurídicos tutelados serem diversos, o non bis in idem no mais das vezes estará preservado.

Exemplificativamente, um servidor que utiliza o carro da Administração fora do horário estipulado e pratica um atropelamento pode ser responsabilizado tanto pela falta administrativa, quanto pelo dano causado a terceiro e também pelo ilícito penal. Cada qual na sua esfera sem ingerências de uma responsabilidade em outra.

4 - As responsabilidades deverão ser apuradas cada qual em seu campo, por intermédio de procedimentos próprios que irão se exteriorizar por intermédio de um processo. Tal processo seguirá seu curso com base em diversos princípios, sendo o mais presente e relevante deles o devido processo legal. Por intermédio dele o processo seguirá seu rumo sempre balizado por lei anterior, e terá em seu regramento prazos que deverão ser cumpridos. Tudo para que a sociedade permaneça em 
harmonia e o Estado em busca de seu objetivo maior o bem comum; sendo assim o due process of law dá ao jurisdicionado segurança jurídica e ao Estado a certeza de estar caminhando para o alcance de seus objetivos.

5 - Neste caminho pavimentado pela segurança jurídica estará a prescrição, para impedir que permaneçam indefinidas situações, para que o futuro não possa ser alcançado sem que haja a certeza do passado.

6 - O Estado busca seus objetivos de manutenção da ordem diante de seus jurisdicionados, e isto também implica em dar a eles deveres, direitos e garantias; com relação àqueles que possuem relação jurídica diferenciada com o Estado, não é diferente e este também obriga àqueles que possuem responsabilidade administrativa a proceder de acordo com o ordenamento.

7 - Existem dentro da Administração pública duas espécies de ilícito administrativo, o ilícito administrativo puro e o ilícito administrativo penal; a diferença entre eles é que o ilícito penal simultaneamente traz responsabilização administrativa e penal, vez que previsto enquanto crime ou contravenção.

8 - Cada qual das espécies de ilícitos administrativos se subdivide em funcionais e disciplinares, sendo apurados por processo administrativo disciplinar.

9 - Os ilícitos administrativos sejam puros ou penais deverão ser - no âmbito da Administração - objeto de um processo administrativo disciplinar que entre seus princípios terá o devido processo legal, inclusive com eventual reconhecimento da prescrição das infrações.

10 - A prescrição de há muito é reconhecida no Brasil perante a Administração Pública, no entanto é voz corrente que no processo administrativo a perda do direito de punir do Estado opera a favor do acusado e contra a Administração, quando o correto seria dizer que a prescrição é sempre a favor do Estado, uma vez que fundada na segurança jurídica, mais que a favor do Estado, a prescrição é a favor da Justiça.

11 - Tal visão míope é traduzida na legislação, em decisões de Tribunais e em pareceres governamentais. A prescrição não é "contra" o poder público, tendo em vista que o Estado é um meio para que se atinja a vida em sociedade, a denominação "prescrição contra o Estado" é inadequada; pois, se a prescrição pretende assegurar a segurança jurídica, necessária para a coexistência pacífica dos indivíduos (que é o bem comum, objetivo maior do Estado) não pode ser taxada como contra o Estado, mas 
sim a favor deste. O prazo prescricional é aplicável ao Estado, fazendo com que este esteja sujeito àquele e isto não prejudica o Estado, mas sim o fortalece; pois, quando temos uma sociedade cujo ordenamento jurídico confiável, que corresponde aos seus anseios, a vida comunitária se torna mais simples e harmônica.

12 - A partir disto os Poderes do Estado, seja por intermédio de leis, de julgados ou de pareceres procuram tornar cada vez mais distante a possibilidade de aplicação do prazo prescricional nos processos administrativos disciplinares.

A regra constitucional é da prescritibilidade, a legislação - no mais das vezes - diz que o prazo começa a correr da ciência da Administração, fazendo com que caso a Administração não esteja ciente a imprescritibilidade impere.

O poder executivo, por seu turno aprovou e tornou vinculante parecer da AGU nos termos seguintes litteris:

A inércia da Administração somente é suscetível de se configurar em tendo conhecimento da falta disciplinar a autoridade administrativa competente para instaurar o processo. Considerar-se a data da prática da infração como de início do curso do lapso temporal, independentemente do seu conhecimento pela Administração, sob a alegação de que a aplicação dos recursos públicos são objeto de auditagens permanentes, beneficiaria o servidor faltoso, que se cerca de cuidados para manter recôndita sua atuação anti-social, viabilizando a mantença do proveito ilícito e a impunidade, bem assim não guardaria conformidade com a assertiva de que a prescrição viria inibir o Estado no exercício do poderdever de restabelecer a ordem social, porque omisso no apuratório e apenação.

E os tribunais, na maior parte das oportunidades dão sustentação a tais pensamentos.

Ora, a prescritibilidade é a regra, constitucionalmente prevista, não pode a Lei - ainda que por via oblíqua - pretender burlar o mandamento maior!

A argumentação do parecer supra transcrito não pode prosperar, pois assume que a Administração não tem total controle e pode desconhecer condutas ilícitas praticadas em seu bojo, o que contraria frontalmente o princípio da eficiência, previsto na Constituição Federal.

Em resumo, a prescrição no processo administrativo disciplinar é a regra do ordenamento jurídico, devendo ser computada 
da data da prática do ato, sendo qualquer manifestação no sentido da contagem somente a partir do momento do conhecimento pela Administração eivada de inconstitucionalidade, por afronta não só à imprescritibilidade como à eficiência que deve pautar a Administração.

Além de todo o exposto, ainda se concluiu no

presente estudo o seguinte:

são prescricionais - e não decadenciais - os prazos para a perda do direito da administração exercer o seu jus puniendi (13);

aplica-se ao processo disciplinar a chamada prescrição intercorrente (14);

é inadequado aplicar ao ilícito administrativo penal a prescrição in concreto, em nenhuma hipótese (15);

é aplicável ao processo administrativo a redução do lapso prescricional nos ilícitos administrativos penais (16). 


\section{BIBLIOGRAFIA}

ALMEIDA, Fernando Dias Menezes de - Aspectos de Processo Administrativo no Ensino Superior. In.Odete Medauar (org.) Processo Administrativo - Aspectos Atuais São Paulo, Cultural Paulista, 1998. - ; MEDAUAR, Odete (org.) ; - Estatuto da Cidade, $2^{\text {a }}$ ed. São Paulo, RT, 2004.

ALMEIDA, Fernando Henrique Mendes de - Noções de direito administrativo, São Paulo, Saraiva, 1956.

ALVES, Vilson Rodrigues: Da Prescrição e da Decadência no Novo Código Civil, Campinas, Bookseller, 2003.

AMORIM FILHO, Agnelo - Critério científico para distinguir a prescrição da decadência e para identificar as ações imprescritíveis, Rio de Janeiro, ed. RF n 193, 1961.

ARANHA, Nário Nunes - Segurança jurídica "stricto sensu” e legalidade dos atos administrativos: convalidação do ato nulo pela imputação do valor de segurança jurídica em concreto à junção da boa-fé e do lapso temporal, Revista de Informação Legislativa, 134:59-73, p. 66, abr./jun. 1997.

ARAPIRACA, Ciro José de Andrade: A Lei 11.280/06 e o reconhecimento de ofício da prescrição, disponível em: www.juspodivm.com.br, acesso em 10 de dezembro de 2008.

ARAÚJO, Edmir Netto de - Contrato administrativo, São Paulo, RT, 1986.

- Curso de Direito Administrativo, 3 ${ }^{\text {a }}$, São Paulo, Saraiva, 2007.

- O ilícito Administrativo e o seu Processo, São Paulo: RT, 1994. - Responsabilidade do Estado por ato jurisdicional, São Paulo, RT, 1981. - Revisão administrativa e prescrição quinquenal, Revista Administração

Paulista da Secretaria de Estado dos Negócios da Administração do Governo do Estado de São Paulo, v. 42, São Paulo, março/abril de 1990.

ÁVILA, Humberto Bergman - Repensando o princípio da supremacia do interesse público sobre o particular, in SARLET, Ingo Wolfgang (Org.). O direito público em tempos de crise. Porto Alegre: Livraria do Advogado Editora, 1999.

ARISTÓTELES - A Política, Tradução de Therezinha Monteiro Deutsch e Baby Abrão, São Paulo, Nova Cultural, 1999.

BANDEIRA DE MELLO, Celso Antônio - Curso de Direito Administrativo, $13^{\text {a }}$ ed. São Paulo, Malheiros, 2001. 
BARROSO, Luís Roberto - Prescrição administrativa, v. 89, n. 779, p. 113-132, RT, set. 2000 .

BATALHA, Wilson de Souza Campos: Lei de Introdução do Código Civil, São Paulo, Max Limonad, 1957.

BERMUDES, Sérgio. A Reforma do Judiciário pela Emenda Constitucional $n^{o} 45$. Rio de Janeiro, Forense, 2005.

BETTI, Emilio: Interpretazione dela legge e degli atti giuridici, Milano: Giuffrè, 1971, e Teoria geral do negócio jurídico, tradução de Fernando de Miranda, Coimbra: Coimbra Ed., 1979.

BITTENCOURT, Cezar Roberto. Tratado de Direito Penal. Parte Geral. Vol. 1, $5^{\mathrm{a}}$ ed, São Paulo, Saraiva, 2003.

BUENO, Cássio Scarpinella - O Poder Público em Juízo, São Paulo, Max Limonad, 2000. CAETANO, Marcello - Manual de Direito Administrativo, Coimbra, Almedina, 1982. - Princípios fundamentais de Direito Administrativo, Rio de Janeiro, Forense, 1977.

CAMARA LEAL, Antonio Luiz da - Da prescrição e da decadência, Rio de Janeiro, Forense, 1982.

CÂMARA, Jacintho de Arruda - Da prescrição e da decadência: teoria geral do direito civil, $3^{\mathrm{a}}$ ed., Rio de Janeiro, Forense, 1978.

CANOTILHO, José Joaquim Gomes - Direito constitucional e teoria da Constituição, $3^{\text {a }}$ ed, Coimbra, Almedina, 1999.

CARPENTER, Luiz F.: Da Prescrição. Artigos 161 a 179 do Código Civil. $3^{\text {a }}$ ed. Rio de Janeiro: Nacional de Direito, 1958. v.1. notas de Arnoldo Wald.

CARRIÓ, Genaro R.: Notas sobre Derecho y Lenguage,Buenos Aires, Abeledo-Perrot, 1976.

CAVALCANTI, Themístocles Brandão - Tratado de Direito Administrativo, $3^{\text {a }}$ ed, Freitas Bastos, 1956.

- Direito e processo disciplinar, 2a ed, Rio de Janeiro, Freitas Bastos, 1966.

CINTRA, Antônio Carlos de Araújo, GRINOVER, Ada Pellegrini e DINAMARCO, Cândido Rangel, Teoria Geral do Processo, 24ª ed São Paulo, Malheiros, 2008.

COUTO E SILVA, Almiro - Princípios da legalidade da administração pública e da segurança jurídica no Estado de Direito Contemporâneo, Revista de Direito Público, v. 84, out.-dez., 1987. 
CRETELLA JÚNIOR, José - Colocação moderna do Direito Administrativo, Editora RF 262:42.

- Curso de Direito Administrativo, Editora Forense, 1989.

- Prática do processo administrativo 6 ${ }^{\mathrm{a}}$ ed, São Paulo, RT, 2008.

- Prescrição Administrativa. in Revista dos Tribunais 544/12, Ed. RT.

- Prescrição da falta administrativa, Editora RT, n. 544, p. 16, fev., 1981.

- Teoria e prática do Direito Administrativo, Editora Forense, 1979.

- Tratado de direito administrativo, Rio de Janeiro, Editora Forense, 1966.

CRUZ, José Raimundo Gomes da - O controle jurisdicional do processo disciplinar, São Paulo, Malheiros, 1996.

DALLARI, Dalmo de Abreu - Processo administrativo, São Paulo, Malheiros, 2001.

DINIZ, Maria Helena - Comentários ao Código Civil. São Paulo, Saraiva, 2005.

DI PIETRO, Maria Sylvia Zanella - Direito Administrativo, Atlas, 2006.

FAGUNDES, Miguel Seabra - Da contribuição do Código Civil para o direito administrativo, Revista de Direito Administrativo, v. 78, p. 1-25, 1964.

FALLA, Fernando Garrido - Tratado de derecho administrativo, Madrid, Editora Tecnos, 1994, v. 1.

FARIAS, Cristiano Chaves de: Direito Civil. Teoria Geral. $3^{\text {a }}$ Edição, Rio de Janeiro, Lúmen Juris 2005.

FERRAZ, Sérgio; DALlARI, Adilson Abreu - Processo Administrativo, São Paulo, Malheiros, 2007.

FIGUEIREDO, Lúcia Valle - Curso de direito administrativo, São Paulo, Editora Malheiros, 1995.

FORSTHOFF, Ernest - Tratado de Derecho Administrativo, Instituto de estudios políticos, Madrid, 1958.

FRANCO SOBRINHO, Manoel de Oliveira - Ética e moralidade nos atos administrativos, in Direito Administrativo na década de 90: Estudos jurídicos em homenagem ao professor José Cretella Júnior, coordenação de Antonio A. Queiroz Telles e Edmir Netto de Araújo, apresentação de Irineu Strenger, Editora RT, São Paulo, 1997.

FRANCO, João Honório de Souza: Responsabilidade extracontratual do Estado e improbidade administrativa, Dissertação de Mestrado FADUSP, São Paulo, 2007.

GARCÍA DE ENTERRÍA, Eduardo; FERNÁNDES, Tomás-Ramón - Curso de direito administrativo, São Paulo, Revista dos Tribunais, 1991.

GASPARINI, Diógenes - Direito administrativo, 6ª ed., São Paulo, Editora Saraiva, 2001. 
GOMES, Orlando: Introdução ao Direito Civil. 6. ed. Rio de Janeiro, Forense, 1979.

GUIMARAES, Francisco Xavier da Silva - Regime disciplinar do servidor público civil da União, $2^{\mathrm{a}}$ ed. Rio de Janeiro, Forense, 2006.

HELLER, Hermann - Teoria do Estado, São Paulo, Mestre Jou, 1968.

HUNGRIA, Nélson - Ilícito administrativo e ilícito penal, Revista de Direito Administrativo (Seleção Histórica, 1945-1995).

JESUS, Damásio Evangelista, Prescrição Penal. 5a, São Paulo, Saraiva, 1990. JÈZE, Gaston - Princípios generales del Derecho Administrativo, Editora Depalma, Buenos Aires, 1949.

LAUBADÈRE, André de - Traité élémentaire de Droit Administratif, Librairie Générale de Droit et de Jurisprudence, Paris, 1963.

LUZ, Egberto Maia - Sindicância e processo disciplinar, Bauru, EDIPRO, 1999.

MASAGÃO, Mário - Curso de Direito Administrativo, Editora Max Limonad, São Paulo, 1960.

MATTOS, Mauro Roberto Gomes de. Lei $n^{\circ}$ 8.112/90 Interpretada e Comentada. Rio de Janeiro: ed. América Jurídica, 2005.

MAYER, Otto - Derecho Administrativo alémán, Editora Depalma, Buenos Aires, 1949.

MEDAUAR, Odete - $O$ direito administrativo em evolução, São Paulo, Revista dos Tribunais, 1992.

MEDAUAR, Odete: A processualidade no Direito Administrativo, São Paulo, RT, 1993.

MEIRELLES, Hely Lopes - Direito Administrativo Brasileiro, 32 a , São Paulo, Malheiros, 2006.

- Prescrição da falta administrativa, RT, n. 55, fev. 1981.

MELlo, Celso Antônio Bandeira de - Elementos de Direito Administrativo, RT, São Paulo, 1987.

MELlO, Oswaldo Aranha Bandeira de - Princípios gerais de Direito Administrativo, Editora Forense, 1974.

MELlO, Rafael Munhoz de: Princípios constitucionais de Direito Administrativo Sancionador - São Paulo, Malheiros, 2007.

MIRABETE, Júlio Fabrini: Manual de Direito Penal, $20^{\text {a }}$ ed, São Paulo, Atlas, 2003.

MIRANDA, Francisco Pontes de - Tratado de Direito Privado, parte geral. $2^{\mathrm{a}}$ ed. Rio de Janeiro. Borsoi, 1955. t. 5 e 6.

MONTEIRO, Washington de Barros - Curso de Direito Civil, São Paulo, Saraiva, 2006. 
MOREIRA NETO, Diogo de Figueiredo - Mutações do direito administrativo, $2^{\mathrm{a}}$, Rio de Janeiro, Renovar, 2001.

MOREIRA, José Carlos Barbosa: Comentários ao Código de Processo Civil vol. V, São Paulo, 13 ${ }^{\mathrm{a}}$ ed, Forense, 2006.

MUKAI, Toshio - Direito administrativo sistematizado, São Paulo, Editora Saraiva, 1999. NASSAR, Elody: Prescriçao na Administração Pública, São Paulo, Saraiva, 2004.

NOGUEIRA, José Carlos de: O Estado é meio e não fim, São Paulo, Saraiva, 1955.

OCTAVIANO, Ernomar; GONSALEZ, Átila J.: Sindicância e processo administrativo, $10^{\mathrm{a}}$ ed, Brasília, Universitária de Direito, 2002.

OLIVEIRA, Régis Fernandes de - Ato administrativo, 4a, São Paulo, RT, 2001.

OSÓRIO, Fábio Medina - Existe uma supremacia do interesse público sobre o privado no direito administrativo brasileiro? RDA, v. 220, p. 69-107, abr./jun., 2000. - Direito Administrativo sancionador, São Paulo, RT, 2000,.

OST, François - O tempo do direito, São Paulo, EDUSC, 2005.

OVIEDO, Carlos Garcia - Derecho Administrativo, Madrid, EISA, 1951.

PEREIRA, Caio Mário da Silva - Instituições de Direito Civil, vol. 1., Rio de Janeiro, Forense, 1994.

PLANIOL, Marcel; RIPERT, Georges - Tratado practico de Derecho Civil Francés: las obligaciones: segunda parte. Habana: Cultural. 1945. t.7. Tradução de Mario Diaz Cruz. PRADO, Leandro Cadenas - Servidores Públicos Federais, 6a , Niterói, Impectus, 2007. QUEIRÓS, Antonio A. Telles; ARAÚJO, Edmir Netto de (Coord.) - Direito administrativo na década de 90: Estudos jurídicos em homenagem ao prof. J. Cretella Júnior, São Paulo, RT, 1997.

RAMOS, Elival da Silva - A Valorização do Processo Administrativo. O Poder Regulamentar e a Invalidação dos Atos Administrativos. In: Carlos Ari Sundfeld e Guillermo Andrés Muñoz. (org.). As Leis de Processo Administrativo (Lei Federal 9.784/99 e Lei Paulista 10.177/98). $1^{\text {a }}$ ed. São Paulo: Malheiros, 2000, v. 1, p. 75-93. - As Leis de Processo Administrativo Federal e Estadual. Disponível em: http://www.tcm.sp.gov.br/legislacao/doutrina/29a03_10_03/3elival_silva1.htm acesso em 20 de dezembro de 2008.

RENAULT, Sérgio Rabello Tamm (coord.); BOTTINI, Pierpaolo Cruz (coord.), Reforma do Judiciário, São Paulo, Saraiva, 2005. 
RIVERO, Jean - Droit Administratif, Ed. Dalloz, Paris, 1980 e a edição portuguesa: Direito Administrativo, tradução de Rogério Ehrhardt Soares, Editora Almedina, Coimbra, 1990.

RIVERO, Jean; WALINE, Jean: Droit administratif, 19 ed., Paris, Daloz, 2002.

RUFFIA, Paolo Biscaretti Di - Direito Constitucional, tradução de Maria Helena Diniz, São Paulo, RT, 1984.

SANTOS, Brasilino Pereira dos. O prazo da prescrição de punição disciplinar começa a correr do momento em que o fato se tornou conhecido? . Jus Navigandi, Teresina, ano 5, n. 51, out. 2001. Disponível em: <http://jus2.uol.com.br/doutrina/texto.asp?id=2278>.

SILVA, Clarissa Sampaio - Limites à invalidação dos atos administrativos, São Paulo, Editora Max Limonad, 2001.

SILVA, José Afonso da, Comentário Contextual à Constituição. São Paulo, Malheiros, 2005.

SOUZA, José Paulo Soriano de. Ensaio sobre a natureza jurídica da prescrição no Direito Civil . Jus Navigandi, Teresina, ano 9, n. 569, 27 jan. 2005. Disponível em: <http://jus2.uol.com.br/doutrina/texto.asp?id=6220>. Acesso em: 13 dez. 2007.

STOCO, Rui - Procedimento administrativo disciplinar no Poder Judiciário, teoria e prática, São Paulo, RT, 1995.

TÁCITO, Caio - Direito Administrativo, São Paulo, Saraiva, 1975.

TELLES, Antonio de Queiroz: Repercussão da sentença penal na esfera administrativa, São Paulo, RT, 2000.

THEODORO JÚNIOR, Humberto: Comentários ao novo Código Civil, vol. 3, t. 2., Rio de Janeiro, Forense, 2003.

UYEDA, Massami - Da competência em matéria administrativa, São Paulo, 1992.

VAROTO, Renato Luiz Mello - Prescrição no Processo Administrativo Disciplinar, São Paulo, RT, 2007.

VEDEL, Georges - Droit Administratif, Paris, Thèmis, 1980.

WALINE, Marcel, Traité élémentaire de Droit Administratif, Paris, Librairie du Recueil Sirey, 1950.

ZANCANER, Weida - Da convalidação e da invalidação dos atos administrativos, $2^{\mathrm{a}}$, São Paulo, Malheiros, 1996. 